\title{
WestVirginiaUniversity
}

THE RESEARCH REPOSITORY @ WVU

West Virginia Agricultural and Forestry Experiment

Davis College of Agriculture, Natural Resources

Station Bulletins

And Design

$1-1-1943$

\section{Livestock Marketing Agencies in West Virginia}

Martin A. Abrahamsen

Follow this and additional works at: https://researchrepository.wvu.edu/ wv_agricultural_and_forestry_experiment_station_bulletins

\section{Digital Commons Citation}

Abrahamsen, Martin A., "Livestock Marketing Agencies in West Virginia" (1943). West Virginia Agricultural and Forestry Experiment Station Bulletins. 312.

https://researchrepository.wvu.edu/wv_agricultural_and_forestry_experiment_station_bulletins/313 @ WVU. It has been accepted for inclusion in West Virginia Agricultural and Forestry Experiment Station Bulletins by an authorized administrator of The Research Repository @ WVU. For more information, please contact ian.harmon@mail.wvu.edu. 
West Virginia University Libraries

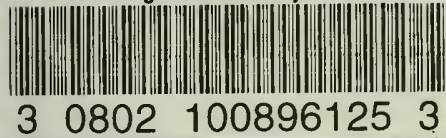





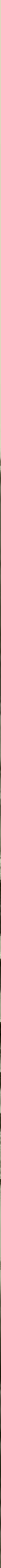




\section{FOREWORD}

Recently many changes have come to the foreground that have a significant influence on methods of buying and selling livestock. To mention a few-roads have been greatly improved; as a consequence, trucks serve as the principal means of transportation; direct selling and buying have become commonplace; and auction markets have developed to the extent that, measured in terms of dollar sales, they are by far the most important marketing agency in the state.

Naturally such changes call for reexamination of the effectiveness with which the various agencies engaged in marketing livestock serve farmers. This study is an attempt to bring together existing information relating to the organization and operation of these agencies. It is hoped that it will be helpful in planning for the establishment of sound operating policies, for it is only as sound policies are established that operating practices helpful to farmers can be put into operation. While problems of marketing are constantly changing, the information obtained and the conclusions reached should be helpful to individuals, to directors, and to managers of the livestockmarketing agencies soliciting business in West Virginia. To the extent that sound principles of marketing serve as a basis for solutions to the marketing problems of livestock producers, the greater are the benefits that farmers obtain. 


\section{CONTENTS}

Purpose and method of study.

Importance of livestock in West Virginia farming

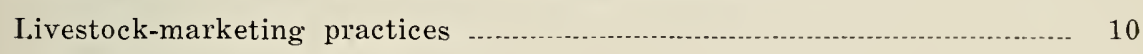

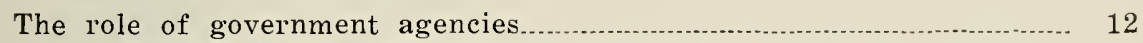

The College of Agriculture, Forestry, and Home Economics....... 12

The West Virginia Department of Agriculture.......................... 13

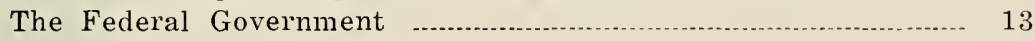

Slaughterhouse operation in West Virginia

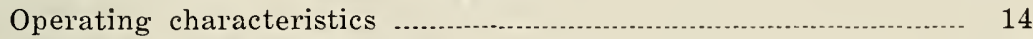

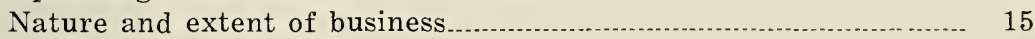

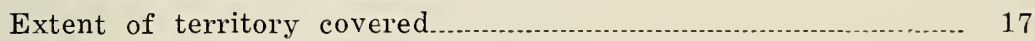

Methods of distributing meat and meat byproducts..................... 19

The place of slaughterhouses in the marketing of livestock -........ 20

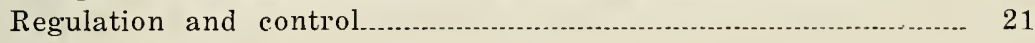

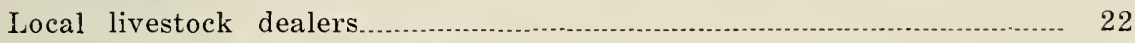

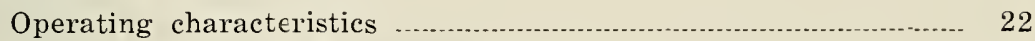

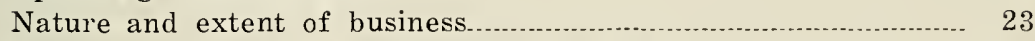

Market agencies used in purchases and sales............................ 24

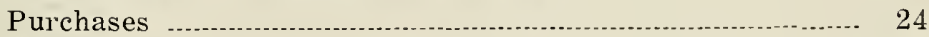

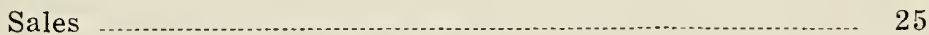

Methods of livestock purchase and sale

Relationship of livestock dealers to other marketing agencies....... 28

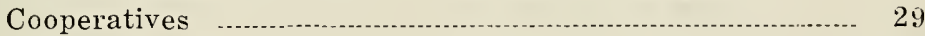

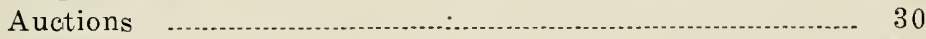

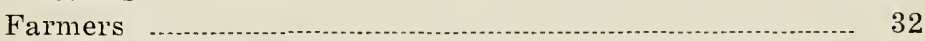

Terminal commission men........................................... 33

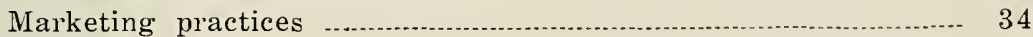

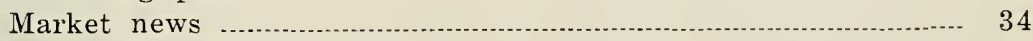

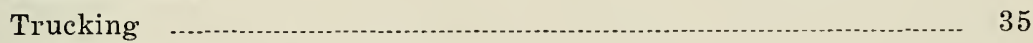

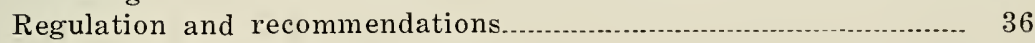

כooperative livestock marketing associations .......................................... 36

Types of cooperative livestock marketing associations.................. 37

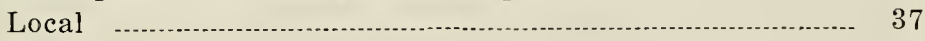

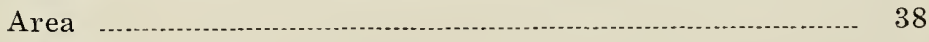

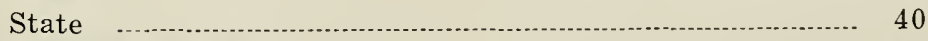

Terminal market ........................................... 40

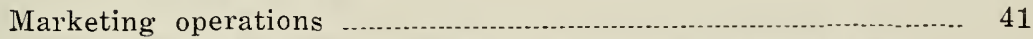

County and area cooperative livestock marketing associations

Nature and extent of cooperative livestock marketing

Relationship to the Eastern Order Buying Company 43

Operating comparisons ..................................... 43

Commission charges ................................ 44

Grading activities .................................... 44

Business records and audits........................ 45 


\section{CONTENTS (Cont.)}

Page

Market territory ............................................... 46

Educational and field work

The West Virginia Livestock Marketing Association..................... 50

Terminal market associations................................................ 51

The Pittsburgh Branch of the Producers Cooperative Commission

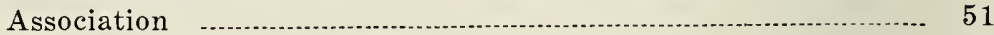

The Pittsburgh market............................................ 51

Operating policies of the Pittsburgh branch..................... 51

Importance of the Pittsburgh branch in the market.......... 53

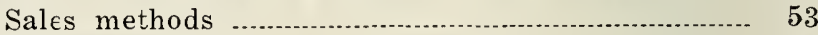

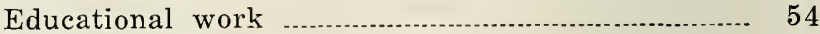

Direct marketing .................................................. 54

Stocker and feeder cattle

Credit association ................................................ 55

Member-relationship problems …............................ 55

Livestock auctions in West Virginia.................................................. 56

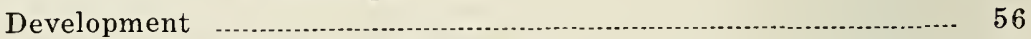

The nature and extent of business............................................... 57

Non-livestock business...................................................... 57

Livestock business ................................................................. 57

Organization …

Capitalization

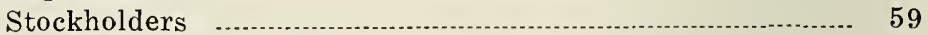

Size of trading territory

Operating facilities .................................................................... 61

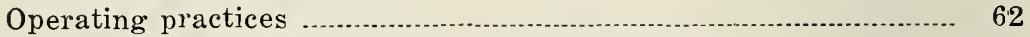

Methods of receiving and dispersing livestock................. 62

Weighing practices of auction markets......................... 63

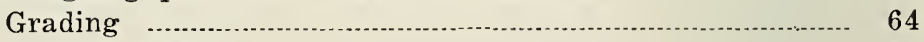

Order of sale

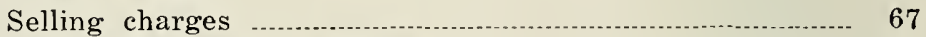

Price-maintenance policies ............................................. 68

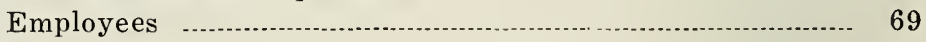

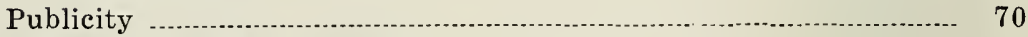

Regulation and supervision.......................................................... 71

Bonding and financial responsibility of traders................. 71

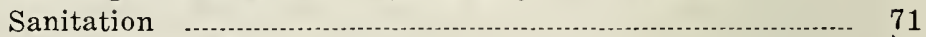

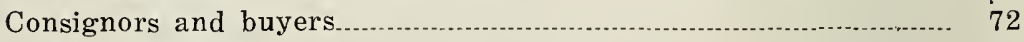

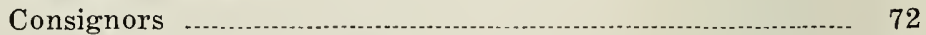

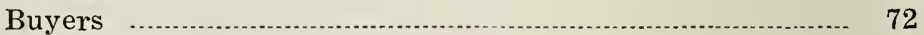

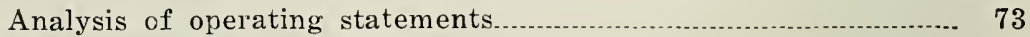

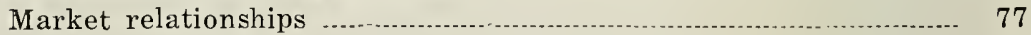

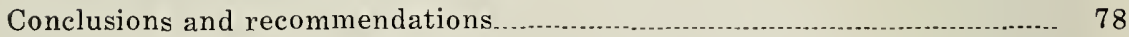

Local slaughterhouses _......................................................... 79

Local livestock dealers...................................................... 79

Cooperative livestock marketing associations............................ 79

Livestock auctions ................................................................... 81 


\title{
LIVESTOCK-MARKETING AGENCIES IN WEST VIRGINIA'
}

\author{
by M. A. Abrahamsen
}

$\mathbf{M}$ ARKED CHANGES have taken place in the marketing of livestock in West Virginia during the past decade. Established marketing agencies - local slaughterhouse operators, local dealers, and cooperative associations-have been forced to modify methods of conducting many business operations. Since 1932, livestock auctions have become the most important marketing agency in the state and have exerted considerable influence on the operating practices of other agencies.

Such factors as highway improvement and changes in marketing methods, particularly direct buying and selling, serve as a background for many changes that have occurred in the organization and opera- tion of livestock-marketing agencies. Because of these changes, many market outlets have developed, and considerable decentralization in organization has resulted. This has led to modification in methods of both sellirg and buying stock. The producer's bargaining power frequently is weakened; often his marketing costs are increased as a resulc of the large number of outlets which receive only limited amounts of stock. Furthermore, the relative importance of central markets as price-determining agencies has changed. The volume of livestock received at central markets has declined; and some of the competition that formerly made its influence felt at these markets has disappeared.

\section{PURPOSE AND METHOD OF STUDY}

Making adjustments to changing conditions calls for examination of the operating practices followed by livestock-marketing agencies in West Virginia. This study was undertaken to obtain information as to the cperating set-up and business practices of local slaughterhouse operators, local dealers, cooperative marketing associations, and auctions
It aimed to describe the nature and extent of business activity, to determine methods of operation, and to obtain information looking toward improvements in certain operating practices. It also was designed to help determine the direction that further investigations might take.

More specifically the purposes of this study include:

${ }^{1}$ Acknowledgment is expressed to Mr. N. L. Claiborne, manager of the Pittsburgh Branch of the Producers Cooperative Commission Association, for furnishing information and for making suggestions col cerning presentation of data on the operations of that association; to Mr. G. M. Robertson, Administrative Assistant, and Mr. W. C. Handlan, in charge of Public Relations, State Department of Agriculture, for furnishing information concerning the contributions of the State Department of Agriculture to livestock marketing; to Mr. French L. Miles, former manager of the Eastern Livestock Marketing Association, Inc., for supplying information relating to the operations of that association; to Mr. C. G. Randell, Principal Agricultural Economist, Cooperative Research and Service Division, Farm Credit Administration, for reading the study in preliminary form and for offering suggestions relating to cooperative livestock marketing associations; and to Professors W. W. Armentrout, Head of the Department of Agricultural Economics, and F. D. Cornell, Jr., of the Department of Agricultural Economics, West Virginia University, for many helpful suggestions. For photographs the author is indebted to Mr. W. M. Nelson of the College of Agriculture. 
1. Obtaining information relating to the development of livestockmarketing agencies and to prevailing market conditions.

2. Determining the nature and extent of business of each of the marketing agencies.

3. Determining and evaluating the relationship of each of the agencies to the other established marketing agencies.

4. Evaluating the organization setup and marketing operations of the local, area, state, and regional cooperative livestock marketing associations.

5. Appraising the development of livestock auctions as they relate to farmer's and to other agencies.

6. Determining and appraising the attitude of farmers toward established marketing agencies.

7. Pointing out some of the possibilities, limitations, and needed adjustments in the operation of livestock - marketing agencies serving West Virginia farmers.

Representatives of the various agencies were interviewed personally by field representatives in the summer of 1940. Special efforts were made to visit livestock auctions and cooperative associations on days of business operation. Agencies interviewed included all slaughterhouse operators, 46 local livestock dealers, all cooperative livestock marketing associations, and all auction markets operating in West Virginia in 1939. (See Fig. 1.) In some instances it has been possible to supplement the data and findings obtained with more recent information.

In addition, 626 farmers from localities selected at random within the eastern, central, and general and dairy types of livestock-producing areas of the state furnished information as to the market agencies used in selling and buying livestock. (See Fig. 2 for the location of types of areas.) They also furnished information as to seasonal distribution of their sales and purchases, the marketing practices they followed, and opinions covering services rendered and performance given by the marliet agencies serving them.

\section{IMPORTANCE OF LIVESTOCK IN WEST VIRGINIA FARMING}

Brief consideration of the place of livestock ${ }^{2}$ in the farming of West Virginia will be helpful in understanding marketing problems. That
West Virginia is predominantly a livestock state is shown by data piesented in Table 1.

Table 1-Sources of Cash Farm Income in West Virginia, 1939 and $1942^{1}$

\begin{tabular}{|c|c|c|c|c|}
\hline \multirow[b]{2}{*}{ Source of income } & \multicolumn{2}{|c|}{1939} & \multicolumn{2}{|c|}{1942} \\
\hline & $\begin{array}{l}\text { Cash } \\
\text { income }\end{array}$ & $\begin{array}{c}\text { Felcentage } \\
\text { of total }\end{array}$ & $\begin{array}{l}\text { Cash } \\
\text { income }\end{array}$ & $\begin{array}{c}\text { Percentage } \\
\text { of total }\end{array}$ \\
\hline & $\$ 1,000$ & percent & $\$ 1,000$ & percent \\
\hline Livestock & & & & \\
\hline Cattle and calves & $\$, 299$ & 20 & 12,465 & 19 \\
\hline Sheep and lambs & 1,968 & 5 & 2,695 & 4 \\
\hline Swine & 2,099 & 5 & 3,772 & 6 \\
\hline Other livestock ${ }^{2}$ & 2,635 & 7 & 7,140 & 11 \\
\hline Total livestock & 15,001 & 37 & 26,072 & 40 \\
\hline Livestock products & 14,288 & 36 & 23,541 & 37 \\
\hline Crops & 10,959 & 27 & 15,085 & 23 \\
\hline Total-all sources & 40,248 & 100 & 64,698 & 100 \\
\hline
\end{tabular}

Compited from data published by the West Virginia Crop and Livestock Marketing Service. Government paynients are not included.

Includes poultry and horses and mules.

"The term "livestrok" is here used primarily to include only cattle, calves, sheep, lambs, and swine. 


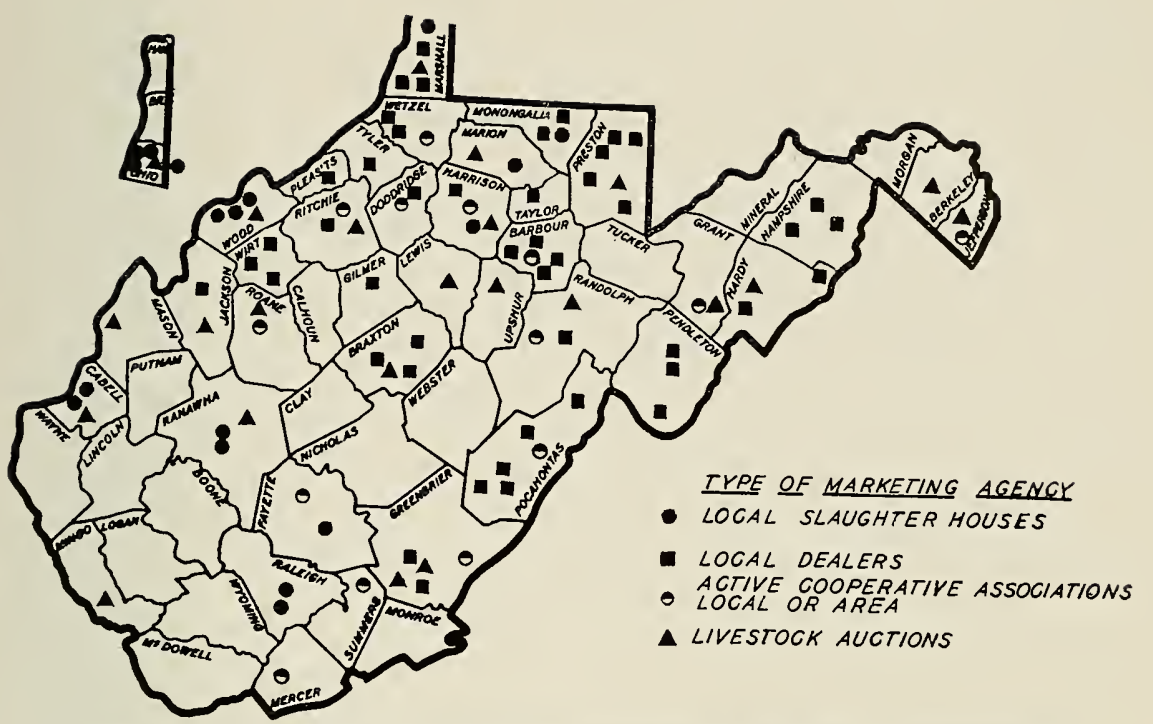

Fig. 1-Location of Livestock-marketing Agencies Interviewed

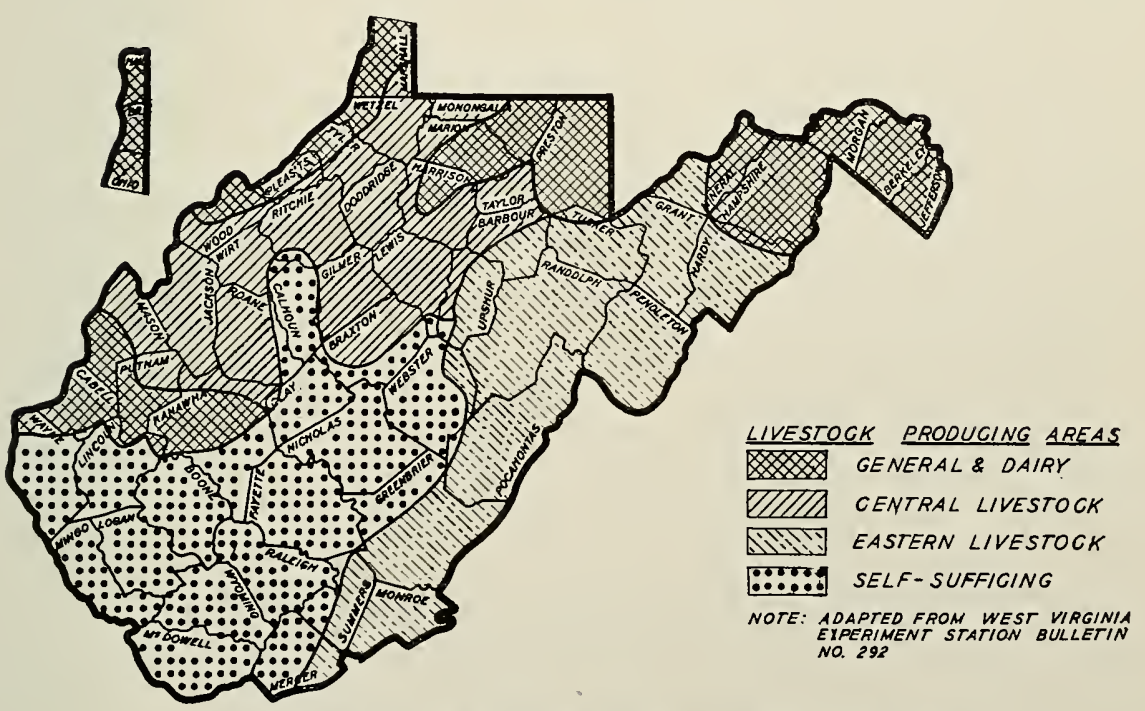

Fig. 2-Type-of-Farming Areas in West Virginia 
In 1942 total cash farm income from the sale of cattle and calves, sheep and lambs, and swine amounted to nearly 19 million dollars, or 29 percent of cash farm income from all sources. Cattle and calves accounted for 66 percent of this amount, sheep and lambs 14 percent. and swine 20 percent. Liyestock and livestock products accounted for nearly 50 million dollars, or 77 percent of the cash farm income of the state. Cash returns from livestock sales in 1942 were slightly more than cash returns from the sale of livestock products. Corresponding data are reported for 1939 , since much of the data presented in this study relate to the 1939 marketing season. It may be noted that little difference exists between data presented for 1939 and 1942. Such differences as do prevail may largely be accounted for in price differences for various species of livestock rather than in relative differences in numbers sold.

Consideration of livestock numbers in the state since 1910 indicates that there have been wide fluctuations, but no major trends, in the various species and classes of livestock considered in this study (16th Census of Agriculture, West Virginia, First Series, p. 8).

Perhaps more indicative of a trend in the beef enterprise than numbers of livestock on farms is the difference in the number of steers in various age groups. According to the
Fourteenth Census of Agriculture [1920], the number of one-, two-, and three-year-old steers in West Virginia was respectively $91,696,63,-$ 191, and 55,352. Comparison with 1930 numbers indicated declines of $29.0,24.3$, and 45.8 percent, respectively, for these age groups during the decade 1920-1930. The primary reason for the relative decline in numbers of three-year-old steers as compared with one- and two-yearold steers, in many instances, is accounted for by increased marketings of feeder calves and one-and twoyear-old animals.

Table 2 gives the number of head of selected species of livestock on farms in West Virginia, as well as the percentage of farmer's reporting cattle and calves, sheep and lambs, and the average number of head of each species and class per farm reporting. (See Fig. 3 for graphic presentation of these data by counties.)

These data supplement those in Table 3, which shows that in West Virginia the size of farm business and the proportion of farmers selling and trading livestock is closely related to the proportion of total income derived by each from selling and trading livestock. It may be noted, for instance, that considerably less than 50 percent of the farmers selling, trading, or using less than $\$ 400$ of farm products sold or traded livestock. On the other hand, livestock

\section{Table 2-Number of Head of Livestock, Percentage of Total Farmers Re- porting, and the Average Number of Head of Livestock Per \\ Farm Reporting, West Virginia, 1940'}

\begin{tabular}{|c|c|c|c|}
\hline Livestock species and class & $\begin{array}{l}\text { Number } \\
\text { reported }\end{array}$ & $\begin{array}{l}\text { Percentage of } \\
\text { total farmers } \\
\text { reporting }\end{array}$ & $\begin{array}{c}\text { Average number } \\
\text { per farm } \\
\text { reporting }\end{array}$ \\
\hline & bead & percent & bead \\
\hline Cattle and calves & 527,067 & 82 & 6 \\
\hline $\begin{array}{l}\text { Cattle and calves other than } \\
\text { dairy cows and heifers }\end{array}$ & 308,298 & & \\
\hline Sheep and lambs & 437,381 & 19 & 23 \\
\hline Swine & 171,765 & 58 & 3 \\
\hline
\end{tabular}

Compiled from the 16th Census of Agriculture, West Virginia, First Series, p. 30. 

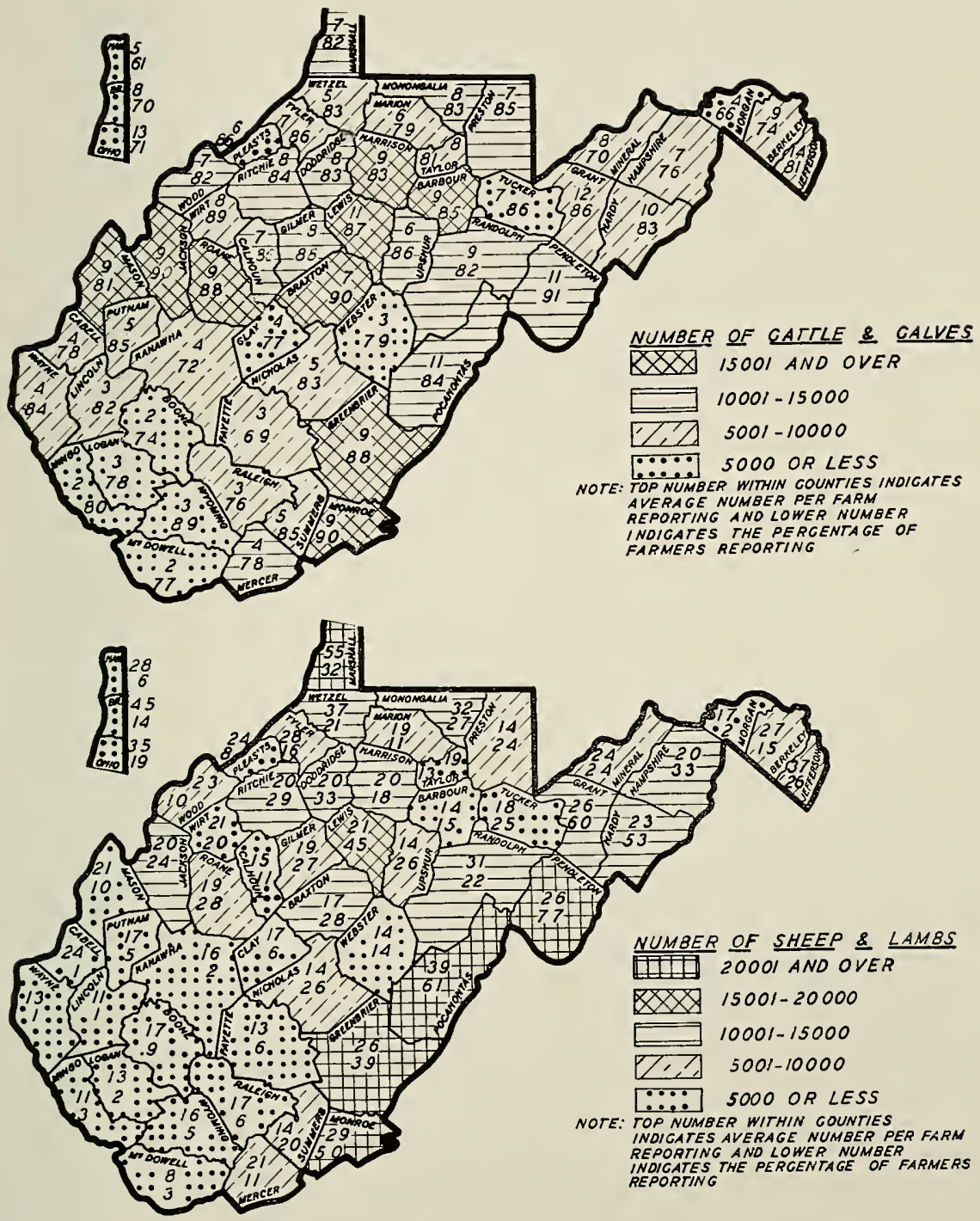

Fig. 3-Cattle and Calves and Sheep and Lambs on Farms in West Virginia, 1940 
Table 3-Relationship of Size of Farm Business to Proportion of all Farms Selling or Trading Livestock and to Other Factors, West Virginia, 1939'

\begin{tabular}{|c|c|c|c|c|c|}
\hline \multirow[b]{2}{*}{$\begin{array}{l}\text { Size of farm business } \\
\text { (Value of products } \\
\text { sold, traded, or } \\
\text { used on farms) }\end{array}$} & \multicolumn{3}{|c|}{ Farmers } & \multirow[b]{2}{*}{$\begin{array}{c}\text { Value of live- } \\
\text { stock sold or } \\
\text { traded per farm } \\
\text { reporting }\end{array}$} & \multirow[b]{2}{*}{$\begin{array}{l}\text { Percentage that sales } \\
\text { and trading of } \\
\text { livestock are of } \\
\text { total farm products } \\
\text { snld or traded }\end{array}$} \\
\hline & Total & $\begin{array}{l}\text { Selling } \\
\text { or trad- } \\
\text { ing live- } \\
\text { stock }\end{array}$ & $\left\{\begin{array}{c}\text { Percent- } \\
\text { age of } \\
\text { total sell- } \\
\text { ing or } \\
\text { trading }\end{array}\right.$ & & \\
\hline dollars & number & number & percent & dollars & percent \\
\hline $\begin{array}{l}\text { Under } 250 \\
250-399 \\
400-599 \\
600-3,999 \\
4,000 \text { and orer }\end{array}$ & $\begin{array}{r}33,305 \\
23,141 \\
18,103 \\
21,467 \\
1,043\end{array}$ & $\begin{array}{r}6,876 \\
10,201 \\
11,068 \\
17,933 \\
852\end{array}$ & $\begin{array}{l}21 \\
44 \\
61 \\
84 \\
82\end{array}$ & $\begin{array}{r}32 \\
55 \\
93 \\
374 \\
3,420\end{array}$ & $\begin{array}{l}28 \\
33 \\
36 \\
41 \\
33\end{array}$ \\
\hline $\begin{array}{l}\text { Total } \\
\text { Average }\end{array}$ & $\begin{array}{r}97,059 \\
\ldots\end{array}$ & 46,930 & $4 \dot{8}$ & 244 & $\dot{3} \dot{8}$ \\
\hline
\end{tabular}

1Compiled from the 16th Census of Agriculture, West Virginia, Third Series, p. 36.

was sold or traded by slightly over 80 percent of the farmers with cash incomes ranging from $\$ 600$ to $\$ 3,999$. As the income from sales or trading increased, the proportion of total income from sales or trading of livestock also had a tendency to increase.

It is important to recognize, however, that, even though farm income from sales and trading of livestock accounts for nearly 40 percent of the total farm income in the state, the small and scattered amounts of marketable livestock are an important item in influencing methods and agencies used in selling livestock for most farmers. Important factors other than size of business which influence the extent of livestock production in West Virginia are altitude, soil type and fertility, slope of land, and nearness to urban centers and mining communities.

\section{LIVESTOCK-MARKETING PRACTICES}

Since farmers raise most of their livestock, sales are more important than purchases in West Virginia (Table 4). Purchases were primarily for the purpose of obtaining breeding animals or feeder stock. Only in the case of hogs are purchases for farm slaughter of any importance. This table also indicates that the number of farmers in the state that reported either buying or selling of various species or classes of livestock was relatively small.

Extent to which various livestock marketing agencies were used by farmers in West Virginia in the sale and purchase of livestock is shown ir Figure 4. Livestock purchases

Table 4-Sale and Purchase of Livestock as Reported for West Virginia, $1939^{1}$

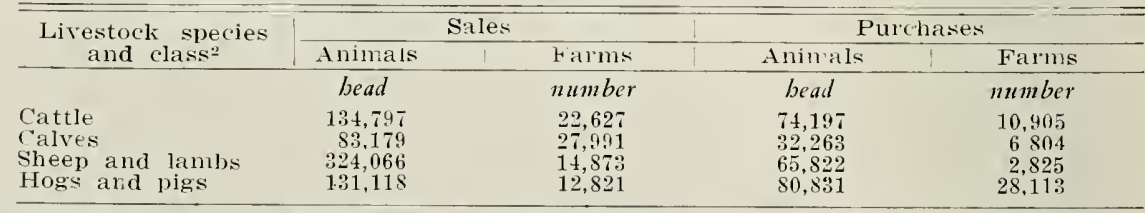

Lompiled from the 16th Census of Agriculture, West Virginia, Second Series, $p .29$. ${ }^{2} \mathrm{Farm}$ slaughter was reported to be $3.9,4.2,15 \mathrm{i} .2$, and 1 percent, respectively, of total sales of cattle, calves, hogs and pigs, and sheep and lambs. 


\section{PERCENI}

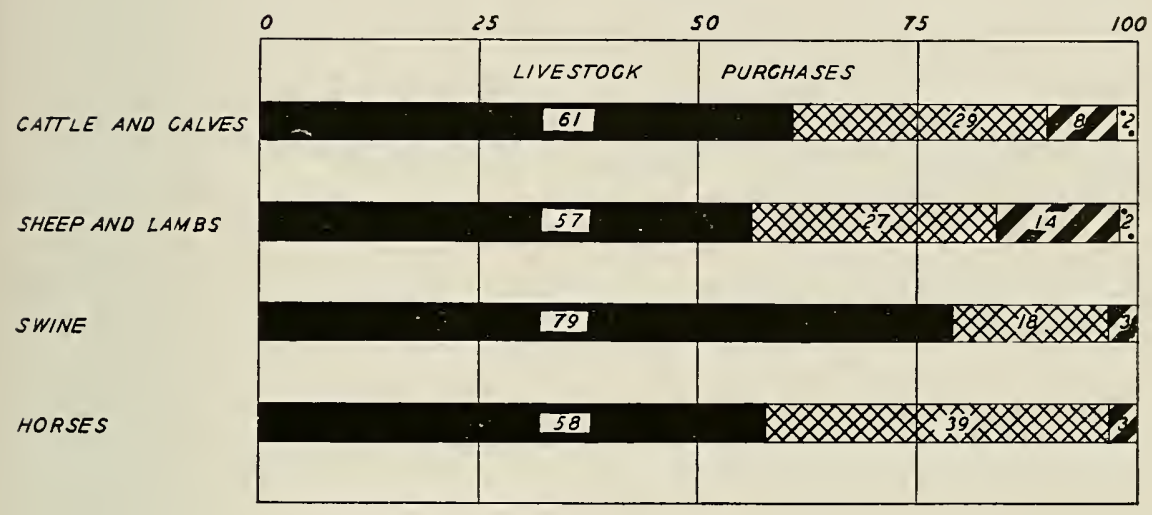

GATTLE AND GALVES

SHEEP AND LAMBS

SWINE

HORSES
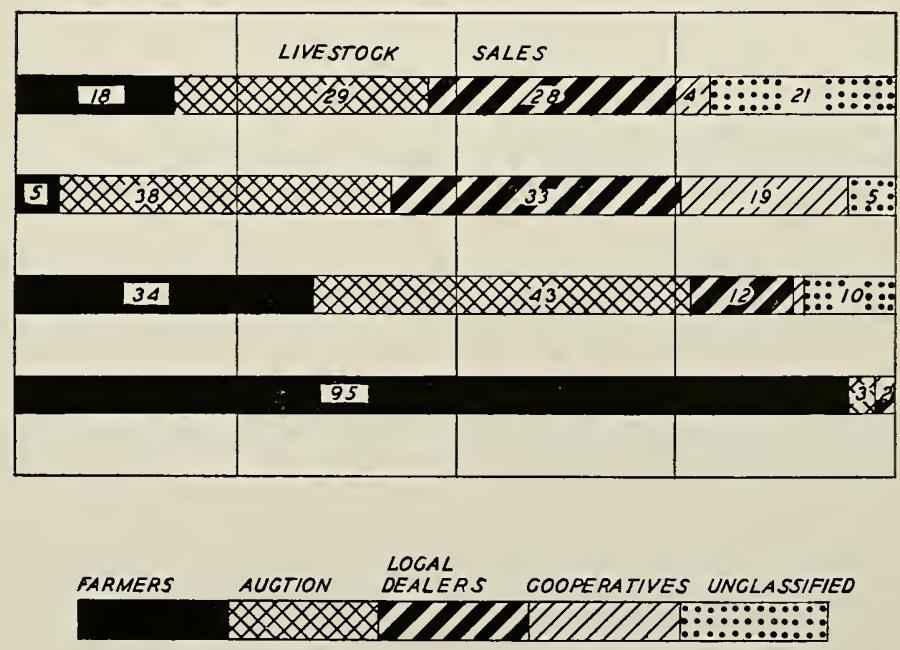

Fig. 4-Market Agencies Used in Purchases and Sales of Livestock, as Reported by 626 Farmers in West Virginia, 1939 
chiefly come direct from farmers and to a limited extent through auctions and local dealers. Auctions, farmers, and local dealers are the most important agencies used by farmers in the sale of livestock. Cooperative associations primarily have devoted their attention to handling sheep and lambs.

Considerable difference existed in the extent to which different agencies were used in purchases and sales of various classes of livestock. Farmers interviewed reported that slightly over 50 percent of the three-year-old steers were sold direct to packers and through private commission men at public stockyards and that only 6 percent were sold through auctions. As a general rule farmers, order buyers, and other local dealers shipped high-grade steers, and to a limited extent heifers, direct to terminal markets. Auctions handled a rela- tively greater portion of the lowergrade slaughter animals and the bulk of the feeder business. As for breeding stock, direct sales by farmers to other farmers continued to be one of the most common outlets. In view of the first-hand information usually available to buyers as to the established reputation of farmers, the continuation of this practice is understandable.

Farmer's reported that approximately two-thirds of the cattle and calves are sold during the three months of August, September, and October; two-thirds of the sheep and lambs during the three months of July, August, and September; horse sales are concentrated in the spring; and swine sales show the least seasonable tendencies. As would be expected, farm purchases, in general, showed similar seasonal trends.

\section{THE ROLE OF GOVERNMENT AGENCIES}

\section{THE COLLEGE OF AGRICULTURE, FORESTRY, AND HOME ECONOMICS}

Through the Department of Animal Husbandry, considerable effort has been directed toward livestock marketing and toward supplementary activities relating to the production and improvement of livestock in West Virginia. Such efforts have taken a number of different courses. The Extension Division through its county agents has aggressively promoted cooperative livestock marketing. County agents are directed to perform much of the clerical work for cooperative livestock marketing associations. They frequently weigh livestock for associations and in some instances work very closely with livestock managers, carrying some share of responsibility for executing operating practices. For a number of years a representative of the state
Extension force has served as auditor for all the cooperative livestock marketing associations in West Virginia. More recently one of the county agents has been authorized to render this service.

State Extension workers in animal husbandry at the College of Agriculture, likewise have aggressively promoted cooperatives. These efforts include consultation with officers of associations in advisory capacities and the sponsoring of numerous contests designed to stimulate interest in cooperative livestock marketing. Through such cooperatives, Extension workers started the practice of grading market lambs according to quality. In conjunction with the State Department of Agriculture the Extension Division has also furnished funds and personnel to assist in conducting various county, area, and state feeder-calf shows and sales, 
purebred-bull and heifer shows, and other related activities.

In addition to these activities, consideraticn is also given to such supplementary uctivities as hay and pasture programs, livestock sanitation, shearing and wool-handling, cowand-calf programs, and bacon-andham shows.

\section{THE WEST VIRGINIA DEPART- MENT OF AGRICULTURE}

The West Virginia Department of Agriculture has taken an active interest in livestock marketing in the state. In 1936 the department provided for the grading of slaughter lambs at concentration points, and during that year 48,563 lambs were graded. By 1941 the department had established slaughter-lamb and calf-grading according to United States tentative grades at 10 livestock auctions and at two area cooperative associations. Grading work is conducted from July to Octobsr, the period of peak marketing. In 1941, 99,502 lambs and 27,753 veal calves were graded. About 80 percent of the lambs and 95 percent of the veal calves were consigned to auction markets; the rest to cooperative associations.

In compliance with state laws, the department conducts blood tests for Bang's disease on all cattle sold at auction that go back to farms, vaccinates for cholera all swine returning to farms, and supervises the dipping of sheep and lambs that are sold for breeding and feeding purposes. All cattle returning to farms are vaccinated for black leg. In 1942 the department also inaugurated the practice of inspecting, for contagious and infectious disease, all horses sold at auction markets. Likewise all animals passing through auction sales are subject to general examination.

The State Department also was in- strumental in enacting legislation pertaining to public markets. While this legislation applies to "any place of business where livestock, poultry, and other agricultural or horticultural products are received and sold at auction," in actual practice it has related primarily to livestock auction markets. The more important provisions of this legislation include: (1) obtaining permits to operate and holding hearings upon the filing of such application for the purpose of determining the advisability of establishing auction markets; (2) revocation and suspension of permits for violation of established rules and regulations; (3) bonding auction operators; (4) licensing weighmen and auctioneers and provisions for the sale of livestock by weight; (5) testing and inspection of livestock for infectious disease, and fees for such testing and inspection; and (6) general provisions relating to grading, activities of weighmen, grades, and auctioneers.

During the grading season, the department furnishes a livestock price reporting service for farmers. Grad. ers telephone daily reports from auction markets, giving the volume of lambs and calves sold and the prices obtained.

\section{THE FEDERAL GOVERNMENT}

Various agencies of the Federal Government, directly or indirectly, have contributed to improvements in the marketing of livestock. One of the most important is the Packer and Stockyards Administration, established in 1921. This agency is charged with such responsibilities as passing upon and establishing salescommission rates; regulating trading practices of stockyard companies, commission firms, and dealers; and the checking of facilities-particuJarly scales. To carry out these responsibilities, all markets comprising 
20,000 square feet or more of yard space are licensed, and all commission men and dealers trading on such markets are required to furnish bonds. Three auction markets in West Virginia are subject to the provisions of the Packer and Stockyards Act.

Other services of the Federal Government include: (1) the market news service of the Bureau of Agricultural Economics, which reports prices and general market conditions for the more important markets sev- eral times daily; (2) establishment of official grades for dressed meats (particularly beef) and certain meat products and grading such products under the jurisdiction of the Agricultural Marketing Service; and (3) the inspection service of the Bureau of Animal Industry, which has responsibility for sanitation practices at established markets and for inspecting slaughter a $\mathrm{n} \mathrm{im} \mathrm{a} \mathrm{ls}$ and dressed meat for compliance with established standards for wholesome food.

\section{SLAUGHTERHOUSE OPERATION IN WEST VIRGINIA}

\section{OPERATING CHARACTER- ISTICS}

Local slaughtering of livestock is a well-established business in West Virginia. In 1940 there were 19 slaughterhouses in operation, each of which had purchased $\$ 25,000$ or more of livestock during the preceding

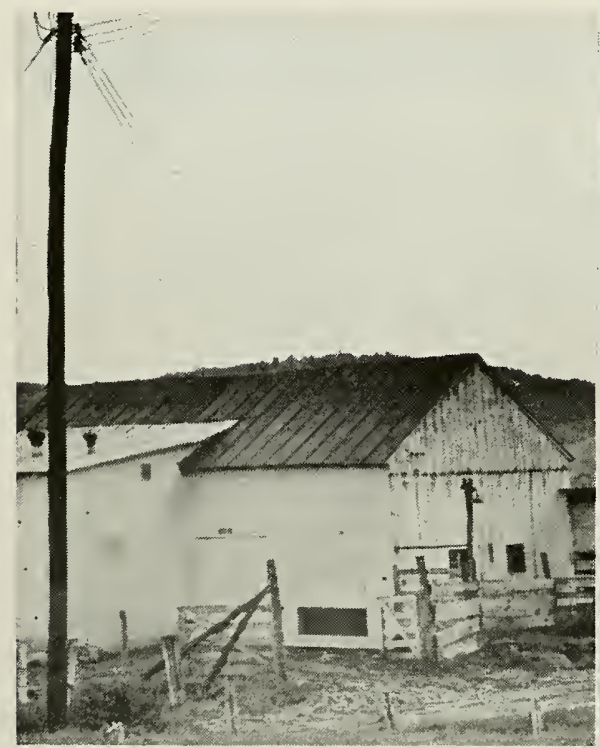

year. Fourteen establishments had been in operation 10 years or more, and six out of this number had been in operation 25 years or more. Slaughterhouses usually are located near centers of population and not necessarily near livestock-producing areas. Hence they are found in the north-

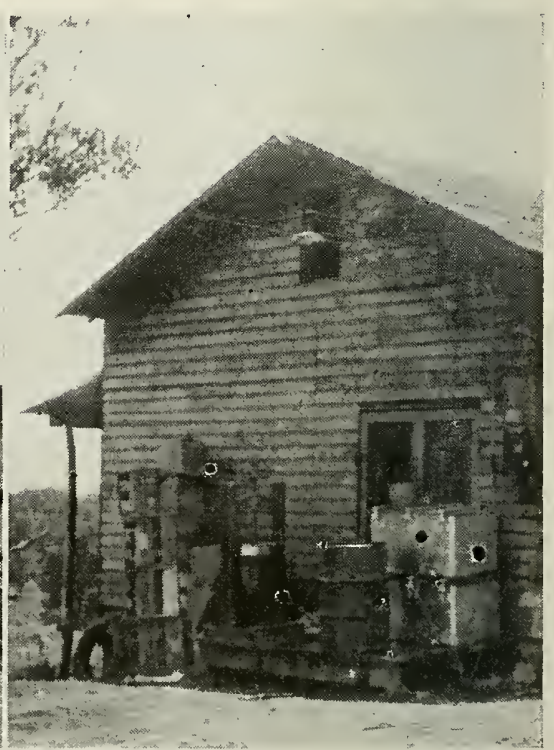

Fig. 5-Representative Local Livestock Slaughterhouses in West Virginia SLAUGHTERHOUSES VARY GREATLY WITH RESPECT TO FACILITIES. SOME ARE EQUIPPED WITH AN ADEQUATE WATER SUPPLY AND WITH ELECTRIC REFRIGERATION; OTHERS DO NOT HAVE SUCH FACILITIES 
ern and southern coal mining regions of the state and in the industrial sections of the Ohio River Valley (Fig. 1).

Methods of business operation vary widely. Seven slaughterhouses were uperated as corporations, six as partnerships, and five as individually owned establishments. Except for one branch plant that was owned and controlled by out-of-state interests, all slaughterhouses were locally owned and operated. The extent of plant facilities and the scope of business operations show wide differences. On one extreme, small plants operated primarily on a family basis and restricted operations usually to the sale of fresh meat. In contrast, the larger plants processed meat and meat byproducts, supplemented the handling of meat with other products (principally eggs, butter, and cheese), and had considerable investment in operating facilities. So m e were equipped to render lard and to manufacture tankage and fertilizer.

\section{NATURE AND EXTENT OF BUSINESS}

Slaughterhouse operators in West Virginia obtained the greater amount of their livestock from auction markets. A sizeable portion, however, came direct from farmers. Irrespective of whether livestock was obtained directly or indirectly from producers, farmers have a definite interest in slaughterhouse operation.
Furthermore, it was reported that practically all the livestock slaughtered and all the meat byproducts prepared by these establishments were sold within the state. Only those slaughterhouses with Federal inspection are permitted to sell in interstate commerce. Consequently the public also has a justifiable interest in slaughterhouse operation. These facts explain why the operation of these establishments is part of a study of livestock marketing. They also serve to indicate their relationship to the various livestock marketing agencies in the state.

While findings in this study were limited to the operations of established slaughterhouses, it is recognized that other types of slaughtering activities are carried on in the state, particularly in the eastern part. Some farmers follow the practice of curing hams and shoulders and of selling such products direct to nearby consumers, to various types of private retail agencies, and to farm supply warehouses. In some instances, particularly in territories serviced by city markets, farmers or retail meat distributors follow the practice of selling various home-prepared meats and meat byproducts. A limited amount of consumer preference has been built up for certain home-prepared products and for some local brands. In addition, some farmers occasionally purchase a few head of stock, slaughter them from

\section{Table 5-Estimated Number of Head of Livestock Purchased, Total Value of Livestock, and Percentage Distribution of Total Value, as Reported for 18 Slaughterhouses in West Virginia, 1939}

\begin{tabular}{lcrc}
\hline \hline Livestock species and class & Number & \multicolumn{2}{c}{ Value } \\
\hline & bead & Total & Percentage of total \\
Cattle & 25,690 & dollars & percent \\
Calves & 11,362 & $1,463,785$ & 69 \\
Sheep and lambs & 5,107 & 151,996 & 7 \\
Swine & 31,664 & 28,318 & 1 \\
Poultry & 25,852 & 453,568 & 12 \\
$\quad$ Total & & $2,111,876$ & 100 \\
\hline
\end{tabular}


CATTLE

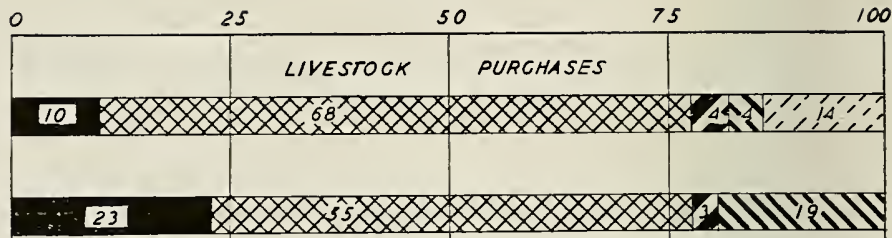

CALVES

23

SHEEP AND LAMBS

SWINE

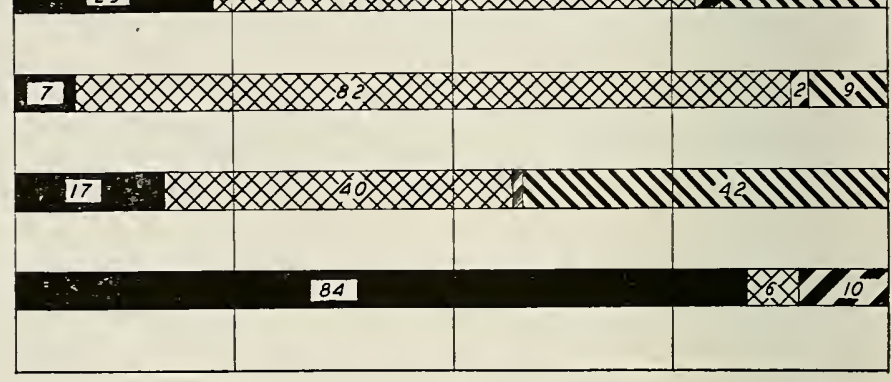

POULTRY

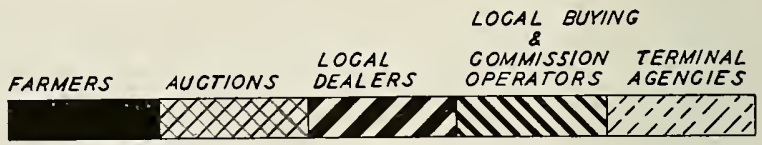

Fig. 6-Market Agencies Used in Purchase of Livestock as Reported by 18 Local Slaughterhouse Operators in West Virginia, 1939

time to time, and peddle homedressed meats-particularly during the winter season. Furthermore, a considerable number of local meat markets do their own butchering and to a limited extent prepare their own meat and byproducts. These practices suggest that wide variation exists in the slaughtering methods practiced in West Virginia.

Table 5 presents the estimated number of head of livestock purchased, the total value of such livestock, and the percentage distribution of total value according to species and class of livestock. In 1939, slaughterhouses in West Virginia purchased $\$ 2,111,876$ worth of livestock. Approximately 69 percent was accounted for by cattle, 7 percent by calves, 22 percent by swine, and 2 percent by sheep and lambs and poultry.

The annual slaughter of cattle, hogs, and poultry per establishment usually was numbered in the thousands of head. As a rule, however, calves, as well as sheep and lambs were slaughtered in annual numbers of less than 500 per plant. All slaughterhouses $\mathrm{s} l \mathrm{a} u \mathrm{~g} h \mathrm{t}$ e $\mathrm{r}$ e d calves; all but one, cattle; 13 , hogs and sheep and lambs; and seven, poultry.

Other indications of variation in size of business were found in the distribution of average annual purchases and in the percentage which purchases in each size group were of total purchases made by slaughterhouses. This distribution in 1939 was as follows:

$\begin{array}{ccc}\begin{array}{c}\text { Annual } \\ \text { purchases } \\ \text { dollars }\end{array} & \begin{array}{c}\text { Slaughter- } \\ \text { houses } \\ \text { number }\end{array} & \begin{array}{c}\text { Percentage } \\ \text { of total } \\ \text { purchases } \\ \text { percent }\end{array} \\ 50,000 \text { or less } & 4 & 7 \\ 50,001-100,000 & \frac{4}{2} & 22 \\ 100,001-200,000 & 4 & 29 \\ 200,001 \text { and over } & 3 & -42 \\ \text { Total } & \overline{18} & 100\end{array}$


Three-fifths of all livestock purchased by slaughterhouses in West Virginia in 1939 came from auction markets, slightly over one-eighth each was from farmers and local buying and commission operators, and somewhat less than one-tenth were from terminal markets. (For details according to species and class see Fig. 6.) Except for poultry, local dealers were not important in supplying slaughterhouses with livestock. Terminal agencies were important only as a source of cattle. Auctions were the most important agency furnishing cattle, calves, and sheep and lambs. The proportion of calves, hogs, and poultry obtained direct from farmers is higher than that of all livestock obtained from farmers. Local buying and commission operators were important primarily as a source of hogs and, to a limited extent, calves.

Terminal markets were used by two slaughterhouses as a source of cattle. While Chicago, St. Louis, and Columbus are the principal terminal markets used, li mited amounts of livestock come from Lancaster, Pennsylvania.

Operators of slaughterhouses reported patronizing 32 livestock auctions in 1939. Sixteen of these were located in West Virginia, 1 in Virginia, 2 in $\mathrm{Pennsylvania,} \mathrm{and}$ 13 in Ohio. Some a ctions are visited on nearly every sales day by the livestock operators. Others are visited only in emergencies or during certain seasons when the type and quantity of livestock desired is available.

Approximately one-half of the purchases made by operators of slaughterhouses seem to be from out of state. Some of the livestock obtained from farmers, all terminal business, and much of the livestock obtained from private buyers and commission operators come from out of state. Often livestock of the desired finish is available in Ohio and Pennsylvania at times when it is not available in West Virginia.

Another indication of the extent to which various agencies we re patronized by slaughterhouse operators may be noted from data presented in Table 6. Most establishments obtain livestock from both auctions and farmers. In contrast, the number of operators patronizing terminal markets, local livestock dealers, and local buying and commission operators was decidedly limited.

\section{EXTENT OF TERRITORY COVERED}

Distribution of purchases according to the distance from slaughterhouses is shown in Table 7. In 1939, approximately 40 percent of all pur-

Table 6-Distribution of Slaughterhouses in West Virginia According to the Agencies from Which Livestock was Purchased, 1939

\begin{tabular}{|c|c|c|c|c|c|}
\hline \multirow{2}{*}{ Agency } & \multicolumn{5}{|c|}{ Livestock species and class } \\
\hline & Lattle & Calves & Hogs & Sheep and lambs & 1 Poultry \\
\hline & \multicolumn{5}{|c|}{ number of slaugbterbonses according to agency used } \\
\hline Terminal market & 2 & & & & \\
\hline $\begin{array}{l}\text { Auction } \\
\text { Local buying and }\end{array}$ & 16 & 16 & 11 & 12 & 1 \\
\hline Local buying and & 1 & 2 & 3 & 1 & \\
\hline Local dealer & 6 & 6 & 2 & 2 & 1 \\
\hline Farmer & 11 & 14 & 7 & 6 & 7 \\
\hline
\end{tabular}




\section{METHODS OF DISTRIBUTING MEAT AND MEAT BYPRODUCTS}

Of the 18 slaughterhouse operators reporting, 6 indicated that 50 percent or more of their total business was accounted for by retail sales from their own establishment. The remaining 12 reported little retailing of their own-in no instance over 10 percent of the total business. Wholesale distribution of meat and meat products is carried on through: retail meat establishments and meat departments of stores, and (2) hotels and lunchrooms. Operators estimated that between 85 and 90 percent of sales were through the former and only 10 to 15 percent through the latter. While all operators reported the first type of business, only 14 reported doing business with hotels and restaurants. In no case did sales to the latter amount to over 25 percent of the total business. Twelve operators reported an average of 142 customers - the number varying from 15 to 500 accounts. Two slaughterhouses have contracts to furnish meat to stores of two of the larger coal companies in the state.

Nine of the slaughterhouse operators reported having their own trucks and salesmen on the road. The number of trucks varied from one for the smaller establishments to as many as seven for some of the larger ones. The common practice for the small establishments was to have truckers act as salesmen or ordertakers. The larger establishments had salesmen taking orders for future delivery. Two operators reported that they did most of their business on the telephone. One operator stated that such business accounted for 99 percent of his total operations.

The proportion of sales and the

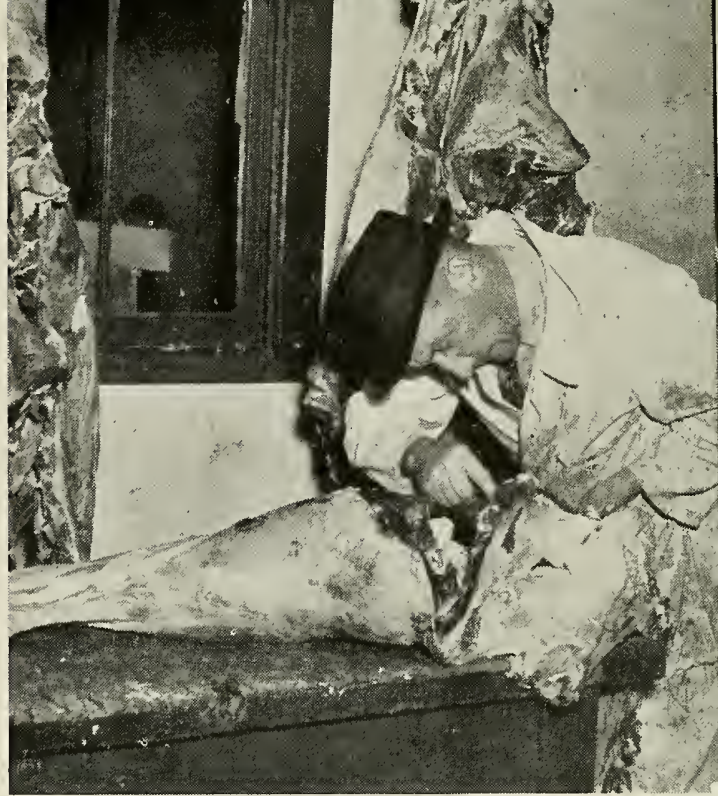

Fig. 8-Preparing Meat for Distribution at Local Slaughterhouses

\section{SOME PLANTS SELL MOST OF THEIR MEAT RE. TAIL AT THEIR OWN ESTABLISHMENTS; OTHERS OPERATE DELIVERY TRUCKS AND SERVE BUTCHER SHOPS, RESTAURANTS, AND HOTELS}

number of slaughterhouses reporting such sales, according to the distance from the slaughterhouse, in 1939 was reported as follows:

\begin{tabular}{|c|c|c|}
\hline Distance & $\begin{array}{c}\text { Slaughter- } \\
\text { houses making } \\
\text { sales }\end{array}$ & $\begin{array}{c}\text { Percentage } \\
\text { of total } \\
\text { business }\end{array}$ \\
\hline 25 or less & $\begin{array}{c}\text { nnmber } \\
18\end{array}$ & $\begin{array}{c}\text { percent } \\
77\end{array}$ \\
\hline $26-50$ & 10 & 11 \\
\hline 51 and over & 7 & 12 \\
\hline
\end{tabular}

These data point to slaughterhouse operation as being primarily a local business. The 11 small establishments reported 93 percent of sales within a 25-mile radius of their plants. The $7 \mathrm{larg}$ e plants did only 50 percent of their business within a 25 -mile radius. The latter reported 20 percent of their business in the 26-50-mile radius and 30 percent in the 51-mile-and-over radius. All the large establishments reported sales within the 26 to 50 -mile radius and all but 1 reported sales at 
distances of 51 miles or over from their plants.

\section{THE PLACE OF SLAUGHTER- HOUSES IN THE MARKET- ING OF LIVESTOCK}

Considerable difference of opinion exists as to the competitive relationship between local slaughterhouses in West Virginia and national packers. Generally, hours were longer and wages lower in local plants. In contrast, limited facilities a $\mathrm{nd}$ disadvantages of small-scale operation of local establishments gave the large plants an advantage. On the other hand, aggressive local operators are in position to render personal service and to establish a local reputation for meat and meat products. As one operator put it, "home-dressed meats and service are our main advantage." It is true that many of the smaller establishments, operating as they do on a family basis, do not lend themselves to comparison with the operating methods of large packers. Indications are that most local slaughterhouse operators can improve their service to consumers and the quality of meat and meat products they handle. Most of them, however, have done little to capitalize on these possibilities.

Wide variation existed in the relationship between slaughterhouses and local marketing agencies-particularly livestock auctions. Six operators expressed definite dissatisfaction arising from such factors as prices, operating practices, and the quantity and quality of livestock available at auctions.

Views expressed by dealers substantiated those of some slaughterhouse operators to the effect that operators usually had to pay more for livestock at auction than if purchases were made direct from farmers. This was well put by one operator who stated that "you have to be the high bidder at the auction, but you could dicker with farmers." Slaughterhouse operators, furtherirore, reported that at times when livestock was scarce, "pinhookers" and auction representatives frequently "punch the stuff up fifty cents per 100 pounds". These practices lead to market disruption, give distorted price information, and serve to hinder orderly marketing.

Possibilities for the development of unsatisfactory market relationships exist when owners of slaughterhouses also are owners or part-owners of livestock auctions. Two operators reported such part ownership. Under such conditions the interest of local operators in obtaining stock at the lowest possible price is definitely in conflict with their interest as auction operators in obtaining the highest possible price for the consignor's livestock. It is impossible to avoid suspicion when slaughterhouse and auction ownership is vested in the same individuals, even though the auction is operated on an ethical basis. That such arrangements cause market complications, however, is evidenced by the experience of one operator, who reported that he was selling his share in an auction because the other shareholders looked to him to support the market when prices were low and competition was limited.

Slaughterhouse operators objected to some of the operating practices of West Virginia auctions-particularly the practice of weighing livestock in. They reported that this practice enabled unethical dealers to "fill" livestock at every opportunity. As a result, allowance had to be made in the prices offered for such stock. Even under ideal conditions, shrinkage amounts to 3 to 5 percent of live weight. Besides, the quality desired could not always be obtained, and the limited amount of some 


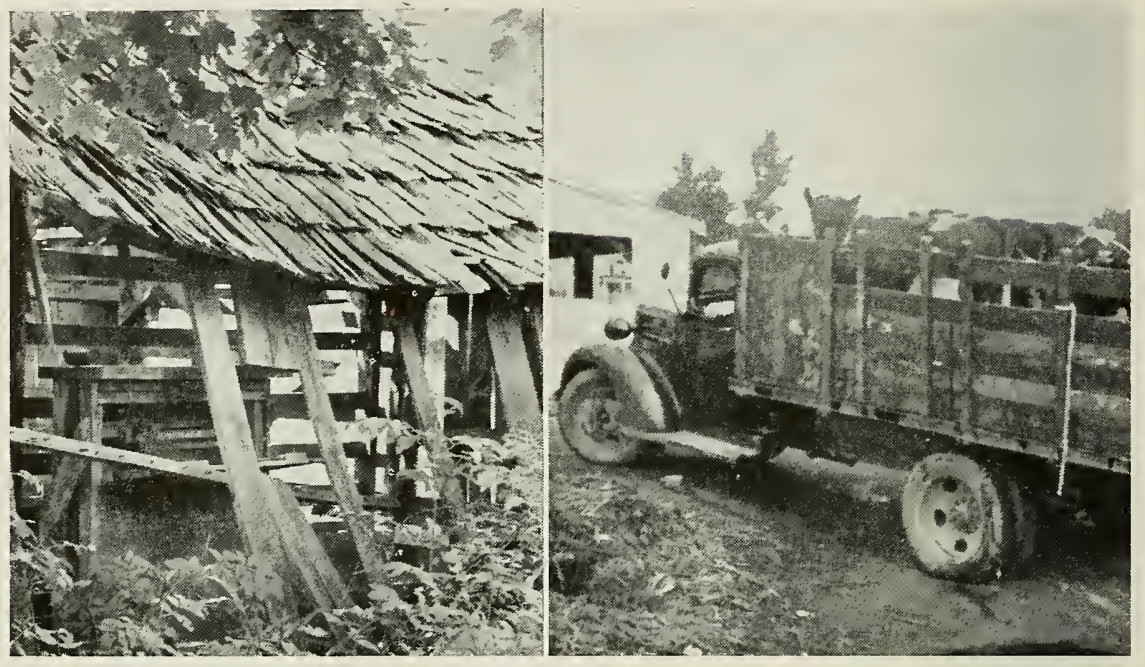

Fig. 10-Abandoned C o u n $r$ y Weighing Facilities of Local Livestock Dealers

\section{EARLY DEALERS HAD THEIR OWN SCALES AND USUALLY ASSEM. BLED LIVESTOCK AT THEIR OWN FARMS}

Fig. 11-Modern Operations of Local Livestock Dealers

\section{IMPROVED ROADS, MOTOR TRUCKS, AND LIVESTOCK AUCTIONS HAVE GREATLY ALTERED OPER- ATING METHODS}

\section{LOCAL LIVESTOCK DEALERS}

Detailed information was obtained from 46 livestock dealers." (For the location of these dealers see Fig. 1.) They comprised approximately onehalf of all the dealers reported in the state and four-fifths of the dealers operating in the principal livestock areas. Since the dealers reporting operated in the principal stock areas, and since the three largest dealers were included, they accounted for from two-thirds to threefourths of the total livestock business conducted by local dealers in the state.

\section{OPERATING CHARACTERISTICS}

The local livestock dealer is a wellestablished institution in West Vir- ginia. The average length of time that dealers have engaged in livestock trading was reported to be 25 years. While many have been in business for ten year's or less, a considerable number have been operating for over 30 years. As reported by 44 local dealers in 1940 , the distribution according to the number of years in business was as follows:

$\begin{array}{cr}\text { Years in business } & \text { Number of dealers } \\ 10 \text { or less } & 14 \\ 11-20 & 7 \\ 21-30 & 10 \\ 31-40 & 6 \\ 41 \text { and over } & 7\end{array}$

It should be remembered that these data apply to dealers actually in business in 1940. Some were "inand-outers," some were forced out

It is recognized that the data presented in this section have certain limitations. Since very few dealers kept actual records, the data were based largely on estimates by dealers. Consequently, some bias may exist. It is believed, however, that these estimates ivill serve as a basis for describing methods of operation and that they will be helpful in contributing to a better understanding of the business practices of local livestock dealers. 
of business during the depression of the 1930's, and still others were retired. Many of those who retired did so because they were not willing to make the adjustments in business methods necessary to enable them to utilize auction and packer agencies for marketing livestock.

\section{NATURE AND EXTENT OF BUSINESS}

Some indication of the nature and extent of business engaged in by livestock dealers in West Virginia is shown by data presented in Table 8 . All but one of the dealers handled cattle, and about four-fifths, twothirds, and one-half, respectively, dealt in calves, sheep and lambs, and swine. Very few handled poultry or horses.

The 46 dealers furnishing data reported the cost of livestock they purchased to be slightly over two million dollars in 1939. Of this amount nearly three-fourths was accounted for by cattle and calves, and slightly over one-fifth by sheep and lambs. Swine, poultry, and horses were of little importance as far as the total volume of business was concerned.

Wide variation exists as to the number of head of various species and classes of livestock purchased by local dealers. For instance, 30 of the 45 dealers who bought cattle purchased less than 200 head although 5 purchased over 1,000 head.
Two-thirds or more of those buying calves, swine, and horses purchased less than 200 head. In contrast only 3 dealers buying sheep and lamos purchased less than 200 head, while 11 purchased over 1,000 head.

Considerabie variation exists in the extent to which various species of livestock were handled (Table 9). For example, 31 of the 45 desiers that handled cattle reported that cattle accounted for 50 percent or more of total purchases, but for sheep and lambs the proportion was considerably less; only 7 of 30 dealers reported that sheep and lambs accounted for over 50 percent of their business.

Of the total volume of purchases reported by 46 dealers, it is significant that the 3 largest accounted tor almost one-half of the total, the 12 largest did three-fourths of the total, and seven-eights of all business was done by the 19 largest dealers-those reporting over $\$ 25,000$ of business annually.

While it is difficult to account for differences in business operations, it seems likely that such factors as: location of dealers with respect to type of livestock producing areas, trucking facilities owned or available, nature of market outlets, and financial status of dealers were considerations in influencing the nature and extent of business transacted.

\section{Table 8-Number of Dealers Handling Livestock, Number of Head Pur- chased, and Total Value of Purchases as Reported by 46 Local Dealers in West Virginia, 1939}

\begin{tabular}{|c|c|c|c|c|}
\hline \multirow{2}{*}{$\begin{array}{c}\text { Livestock species } \\
\text { and class }\end{array}$} & \multirow{2}{*}{$\begin{array}{l}\text { Dealers } \\
\text { reporting }\end{array}$} & \multirow{2}{*}{$\begin{array}{l}\text { Number } \\
\text { purchased }\end{array}$} & \multicolumn{2}{|c|}{ Value of purchases } \\
\hline & & & A $\operatorname{lount}$ & Percentage of total \\
\hline & number & bead & dollars & percent \\
\hline $\begin{array}{l}\text { Cattle } \\
\text { Calves } \\
\text { Sheep and lambs } \\
\text { Swine } \\
\text { Horses } \\
\text { Poultry }\end{array}$ & $\begin{array}{l}45 \\
36 \\
30 \\
2 \frac{2}{8} \\
5\end{array}$ & $\begin{array}{r}22,227 \\
6,932 \\
76,115 \\
4,425 \\
423 \\
4,450 \\
\end{array}$ & $\begin{array}{r}1,+22,749 \\
112,195 \\
447,152 \\
43,265 \\
43,525 \\
2,310 \\
\end{array}$ & $\begin{array}{r}69 \\
5 \\
22 \\
2 \\
2 \\
\\
\end{array}$ \\
\hline Total & & & $2,071,196$ & 100 \\
\hline
\end{tabular}

${ }^{1}$ Less than 0.5 percent 
For instance, most of the smaller dealers operated trucks and frequented territories of limited livestock development or of dairy and general-farming areas. Consequently, cattle and calves were the more important species of livestock handled. Some of the larger dealers, in turn, did a considerable amount of "order business" for packers or other buyers on an outright purchase basis. Since most of this business was in cattle and lambs, it helped to explain the large proportion of such business for these dealers.

The relationship of type of livestock-producing areas to size of dealer business is shown by the fact that annual purchases in the eastern and central livestock areas averaged $\$ 51,000$ and $\$ 56,000$, respectively, in 1939, while such purchases in dairy and general-farming areas averaged only $\$ 24,000$. Those dealers who specialized in sheep and lambs did considerably less yearly business than those specializing in cattle. The 7 dealers who reported that sheep and lamb purchases made up over 50 percent of their business had an average annual business in 1939 of $\$ 37,000$, while the 16 dealers who reported that cattle purchases accounted for 75 percent or more of their business averaged in $1939 \$ 67,000$.

Other differences existed also. In the eastern livestock area, the sheep and lamb business of livestock dealers was only slightly less important than the cattle business. In the other areas this business amounted to less than 10 percent of the cattle business; and it was only in the dairy and general livestock areas that dealing in horses and swine was an important part of the business. It is, of course, true that some dealers frequently went out of the areas in which they live to obtain some of the livestock they handle.

\section{MARKET AGENCIES USED IN PURCHASES AND SALES}

Purchases: Dealers relied almost entirely on farmers and livestock auctions as sources of supply for the livestock they purchased (Fig. 12). Except in the case of calves and horses, three-fourths or more of all livestock purchased came direct from the farm. Practically all the remainder came from livestock auctions.

The distribution of total purchases according to source was reported by 45 local dealers in 1939 as follows:

\begin{tabular}{lrc} 
Sources of purchases & \multicolumn{2}{c}{ Purchases } \\
& dollars & percent \\
Farmer & $1,549,956$ & 75 \\
Auction & 487,122 & 24 \\
Dealer and other & 30,118 & 1 \\
$\quad$ Total & $2,067,196$ & -100
\end{tabular}

For dealers in the various types of farming areas, some differences existed as to the percentage of cattle, calves, and sheep and lambs purchased at auctions and from farmers. As reported by the local deal-

Table 9-Distribution of Number of Livestock Dealers According to the Percentage of Business Accounted for, as Reported by Local Dealers in West Virginia, 1939

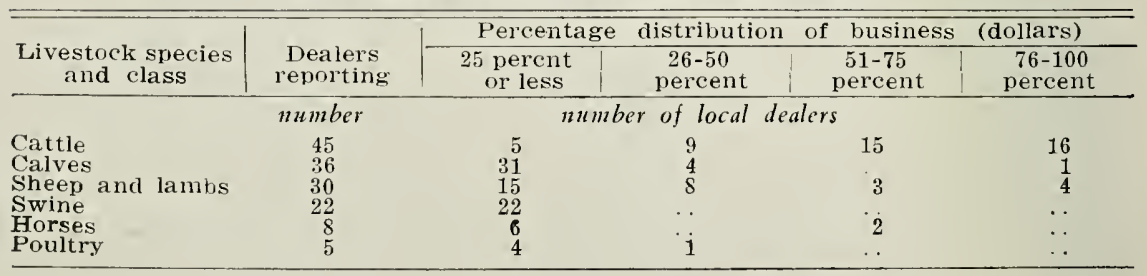


ers in each area, the percentage distribution, according to source, was as follows:

$\begin{array}{lcc}\begin{array}{c}\text { Livestock species and } \\ \text { class and type of } \\ \text { producing area }\end{array} & \text { Auction } & \text { Farme } \\ \text { Cattle } & \text { percent } & \text { percent } \\ \text { Eastern livestock } & 6 & 94 \\ \text { Central livestock } & 41 & 59 \\ \text { Dairy and general } & 14 & 86 \\ \text { Calves } & & \\ \text { Eastern livestock } & 28 & 72 \\ \text { Central livestock } & 79 & 21 \\ \text { Dairy and general } & 39 & 61 \\ \text { Sheep and lambs } & & \\ \text { Eastern livestock } & 8 & 92 \\ \text { Central livestock } & 42 & 58 \\ \text { Dairy and general } & 25 & 75\end{array}$

These data indicate that farmers were considerably more important as a source of supply for dealers in the eastern livestock area than in the central area. The fact that dealers usually were able to obtain stock in larger lots direct from farmers in the eastern area accounted in part for this situation.

When classified according to size of annual purchases, local dealers reported no marked difference as to source of supply, except that the smaller dealers obtained an appreciably larger proportion of calves at auctions. On the basis of this classification, dealers in 1939 reported the sources of livestock as follows:

\begin{tabular}{|c|c|c|}
\hline $\begin{array}{l}\text { Size of dealer and } \\
\text { Livestock species } \\
\text { and class }\end{array}$ & $\begin{array}{l}\text { Source o } \\
\text { Auction }\end{array}$ & $\begin{array}{l}\text { livestoch } \\
\text { Farmer }\end{array}$ \\
\hline $\begin{array}{l}\text { Under } \$ 50,000 \text { yearly } \\
\text { Cattle } \\
\text { Calves } \\
\text { Sheep and lambs }\end{array}$ & $\begin{array}{l}23 \\
28 \\
10\end{array}$ & $\begin{array}{l}77 \\
72 \\
90\end{array}$ \\
\hline $\begin{array}{l}\text { Over } \$ 50,000 \text { yearly } \\
\text { Cattle } \\
\text { Calves } \\
\text { Sheep and lambs }\end{array}$ & $\begin{array}{l}28 \\
71 \\
16\end{array}$ & $\begin{array}{l}72 \\
29 \\
84\end{array}$ \\
\hline
\end{tabular}

A relatively large proportion of total business was within a 25-mile radius. Except for cattle, calves, and horses, over 50 percent of other species of livestock came from within this distance of the dealers' place of business.

Nearly one-half of all purchases (expressed in dollars) were from within a distance of 25 miles; the remaining purchases were about evenly divided between distances of 26-50 miles and 51 miles and over. As reported by 44 local dealers in 1939, this distribution was as follows:

\begin{tabular}{ccc} 
Distance & \multicolumn{2}{c}{ Purchases } \\
miles & dollars & percent \\
25 or less & 936,093 & 47 \\
$26-50$ & 507,681 & 25 \\
51 and over & 555,049 & 28 \\
Total & $1,998,823$ & $-\frac{100}{100}$
\end{tabular}

Sales: Dealers disposed of their livestock primarily through four agencies (Fig. 12). Terminal agencies took nearly one-half of the cattle, two-fifths of the calves, one-fifth of the swine, and one-third of the sheep and lambs. Sales direct to packers accounted for about onefourth of the cattle, one-fourth of the calves, one-eighth of the swine, and nearly one-half of the sheep and lambs. Dealers reported that about one-tenth of the cattle, slightly over one-fifth of the calves and swine, and one-seventh of the sheep and lambs were sold through auctions. Sales to farmers were most significant in the case of horses, swine, poultry, and, to a limited extent, cattle. Sales to unclassified agencies, which include local butchers and packers, were not important except for poultry.

That considerable difference existed as to the sales agencies used for cattle and sheep and lambs by dealers in different farming areas is seen by examination of Table 10 . Dealers in the central livestock area sold over two-fifths of their cattle and over half of their sheep and lambs to terminal agencies and nearly as large a proportion direct to packers. This naturally limited sales to other agencies. Over one-half of the sheep and lambs handled by eastern dcalers moved direct to packers, while over three-fifths of the cattle were sold through terminal agencies. While dealers in the dairy and general-farming areas sold neither cat- 


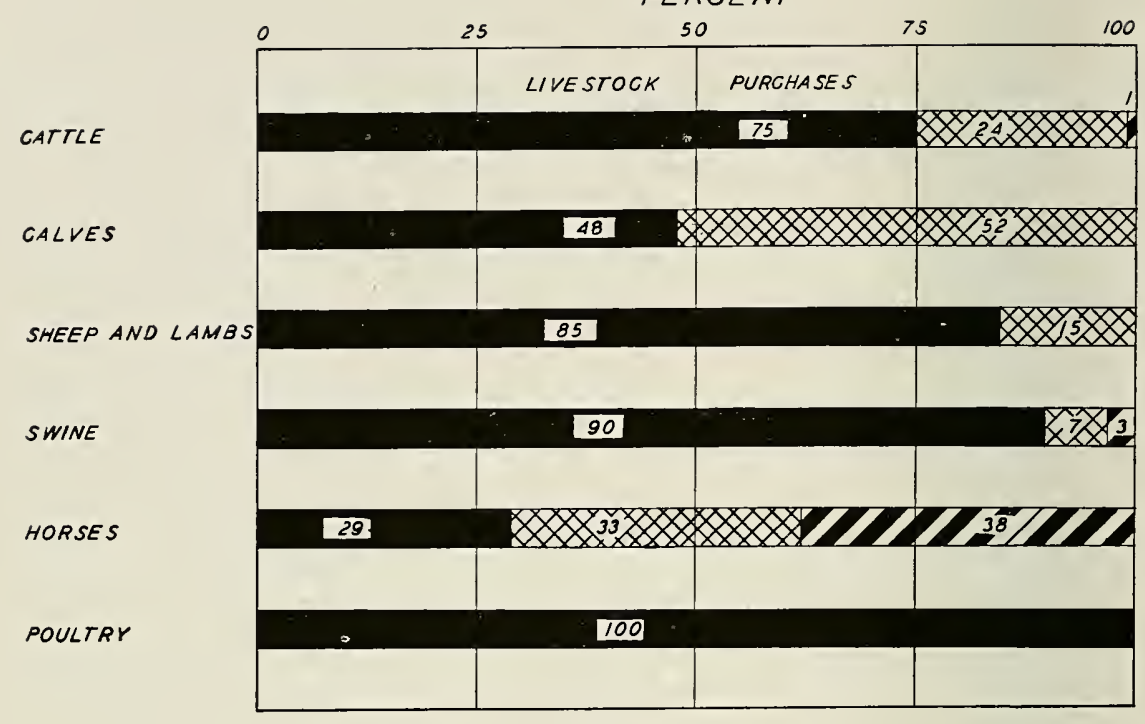

CATTLE

CALVES

SHEEP AND LAMBS

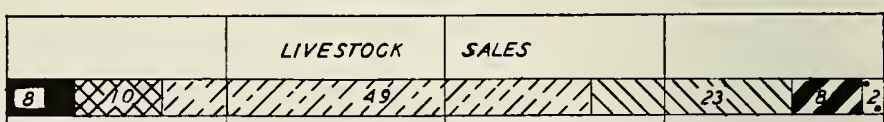

SWINE

HORSES

POULTRY
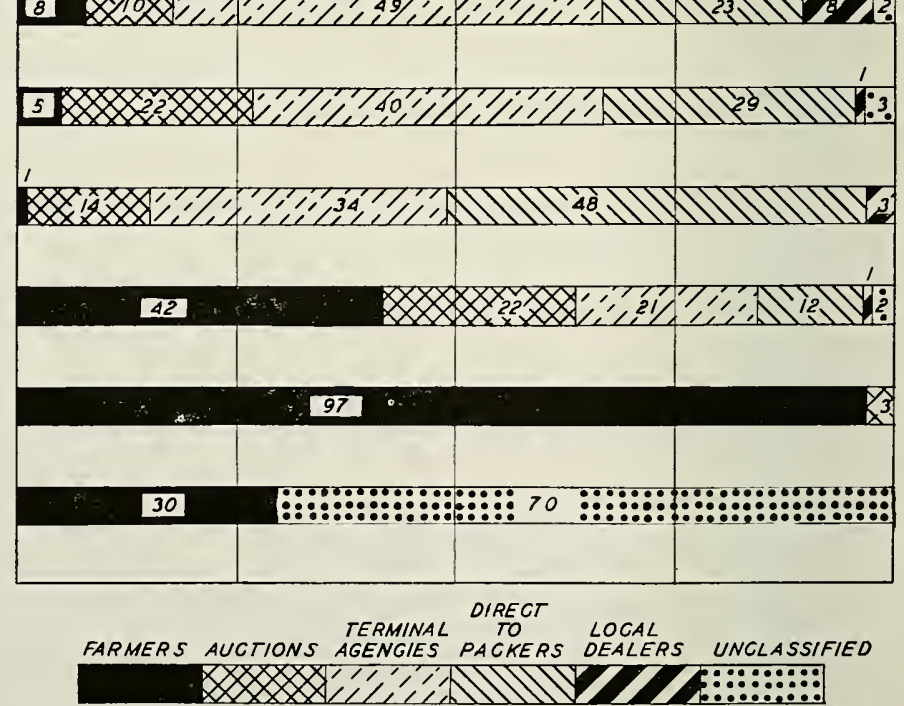

Fig. 12-Market Agencies Used in the Purchase and Sale of Livestock, as Reported by 45 Livestock Dealers in West Virginia, 1939 
Table 10 -Percentage Distribution of Cattle and Sheep and Lamb Sales According to Type of Farming Area and Location of Local

Dealers, as Reported by 46 Dealers in West Virginia, 1939

\begin{tabular}{|c|c|c|c|c|c|c|}
\hline \multirow{2}{*}{$\begin{array}{l}\text { Livestock species } \\
\text { and class and type } \\
\text { of livestock-produc- } \\
\text { ing area }\end{array}$} & \multicolumn{6}{|c|}{ Percentage of total sales to: } \\
\hline & $\begin{array}{l}\text { Terminal } \\
\text { agencies }\end{array}$ & $\begin{array}{l}\text { Direct to } \\
\text { packers }\end{array}$ & $\begin{array}{l}\text { Livestock } \\
\text { auctions }\end{array}$ & Farmers & $\begin{array}{l}\text { Local } \\
\text { dealers }\end{array}$ & $\begin{array}{l}\text { Unclassified } \\
\text { agencies }\end{array}$ \\
\hline & percent & percent & percent & percent & percent & $t \quad$ percent \\
\hline $\begin{array}{l}\text { Cattle } \\
\text { Eastern livestock } \\
\text { Central livestock } \\
\text { Dairy and general }\end{array}$ & $\begin{array}{l}63 \\
43 \\
50\end{array}$ & 40 & $\begin{array}{r}16 \\
3 \\
21\end{array}$ & $\begin{array}{r}13 \\
3 \\
16\end{array}$ & $\begin{array}{r}1 \\
11 \\
6\end{array}$ & $\begin{array}{l}2 \\
7\end{array}$ \\
\hline $\begin{array}{l}\text { Sheep and lambs } \\
\text { Eastern livestock } \\
\text { Central livestock } \\
\text { Dairy and general }\end{array}$ & $\begin{array}{l}29 \\
52 \\
46\end{array}$ & $\begin{array}{l}53 \\
36 \\
\ldots\end{array}$ & $\begin{array}{l}14 \\
12 \\
39\end{array}$ & $\begin{array}{l}\cdots \\
14\end{array}$ & $\begin{array}{l}4 \\
\cdots \\
\cdots\end{array}$ & $\begin{array}{l}\cdots \\
i\end{array}$ \\
\hline
\end{tabular}

tle nor sheep and lambs direct to packers, they moved a significant proportion of such livestock through terminal agencies. Sales by dealers through auctions were highest in the dairy and general livestock producing areas. This was due in part to the small lots handled by these dealers and in part to the fact that only a small proportion of livestock in this region was of the quality demanded at central markets.

Livestock dealers were asked to give estimates of the percentages of various species and classes of livestock bought and sold for slaughter, feeder, and breeding purposes (Table 11). Sales of breeding animals did not constitute an important part of operations. About seven-tenths of the cattle and hogs and about ninetenths of the calves and sheep and lambs were both purchased and sold for slaughter.

An appreciable percentage of the sales to auctions, practically all sales to terminal agencies, and all sales made direct to packers constituted slaughter animals. Hence a close relationship existed between the kinds of livestock handled and the agencies to which such stock was sold. A possible exception was swine. Since only 69 percent of swine were reported as slaughter animals, and since sales to all agencies other than farmers accounted for only 58 percent of the swine sold, 't is evident that a considerable proportion of the swine sold to farmers was slaughtered.

Dealers that bought the greater proportion of their livestock at auctions sold more livestock direct to packers than through any other outlet. In contrast, dealers who bought the greater proportion of livestock at

Table 11-Destination of Livestock Purchases and Sales as Reported by 44 Local Dealers in West Virginia, 1939

\begin{tabular}{|c|c|c|c|}
\hline \multirow{2}{*}{$\begin{array}{c}\text { Type of dealing according } \\
\text { to livestock species and } \\
\text { class }\end{array}$} & \multicolumn{3}{|c|}{ Percentage of livestock classified as: } \\
\hline & Sla'ighter & Feeder & Breeding \\
\hline & percent & percent & percent \\
\hline $\begin{array}{l}\text { Purchases } \\
\text { Cattle }\end{array}$ & 69 & 30 & 1 \\
\hline Calves & 89 & 10 & 1 \\
\hline Sheep and lambs & 91 & 4 & 5 \\
\hline Swine & i1 & 29 & . \\
\hline Sales & & & \\
\hline Cattle & 73 & 26 & 1 \\
\hline $\begin{array}{l}\text { Calves } \\
\text { Sheen }\end{array}$ & 90 & 9 & $\begin{array}{l}1 \\
2\end{array}$ \\
\hline $\begin{array}{l}\text { Sheep and linmbs } \\
\text { Swine }\end{array}$ & $\begin{array}{l}95 \\
69\end{array}$ & 31 & . \\
\hline
\end{tabular}


farms sold over two-thirds of their cattle and one-third of their sheep and lambs through terminal agencies. Sales at auctions were relatively less for dealers purchasing primarily at auctions than for those purchasing at farms (Table 12).

The fact that most dealers that sold to packers operated with orderbuying agreements meant that to get sufficient volume they had to go either to auctions or to large producers of livestoci. Dealers buying from farmers experienced greater variation in the volume of available livestock, and as a rule they found it to their advantage under such conditions to deal with terminal agencies. Dealers purchasing from auctions primarily sold only odd-lot animals through auctions. Some dealers that purchased at farms regularly, used auctions for a part or all of their sales.

\section{METHODS OF LIVESTOCK PURCHASE AND SALE}

Data relating to methods of purchase and sale are presented in $\mathrm{Ta}$ ble 13. Between three-fifths and three-fourths of the cattle, calves, and swine and over nine-tenths of the sheep and lambs were purchased by weight. Local dealer's function, to a large extent, to concentrate livestock from individual producers. Under such conditions many purchased on a per-head basis because no weighing facilities were available or because they desired to buy on a bargaining basis. In contrast, they like to sell by weight because they often sold in lots and because this method of sale enabled them to capitalize on their bargaining ability.

The increase in the proportion of total sales by weight as compared with rotal purchases by weight was particularly important in the case of cattle and calves. This increase also was more marked for small dealers than for large ones (Table 13).

As for differences according to type of livestock-producing area, with the exception of calves in the eastern area, the proportion of purchases on a head basis was appreciably higher in the dairy and general area than in either the eastern or central livestock areas. These considerations lead to the conclusion that if it is good policy for dealers to sell by weight, farmers might plofit by following this example.

\section{RELATIONSHIP OF LIVESTOCK DEALERS TO OTHER MAR- KETING AGENCIES}

Livestock dealers have developed definite relationships with other live-

\section{Table 12-Relationship Between Types of Livestock Dealers, Classified Ac- cording to Concentration of Purchases, and Agencies to Whom Sales Were Made, as Reported by Dealers in West Virginia, 1939}

\begin{tabular}{|c|c|c|c|c|c|}
\hline \multirow{2}{*}{$\begin{array}{c}\text { Type of livestock dealers } \\
\text { according to concentration } \\
\text { of purchases }\end{array}$} & \multirow[b]{2}{*}{$\begin{array}{l}\text { Dealers } \\
\text { reporting }\end{array}$} & \multicolumn{4}{|c|}{ Percentage of total sales to: } \\
\hline & & $\begin{array}{l}\text { Terminal } \\
\text { agencies }\end{array}$ & $\begin{array}{l}\text { Direct to } \\
\text { packers }\end{array}$ & $\begin{array}{l}\text { Auc- } \\
\text { tions }\end{array}$ & $\begin{array}{l}\text { Unclassifled } \\
\text { agencies }\end{array}$ \\
\hline Deglercin cattle wenorting. & number & percent & percent & percent & percent \\
\hline $\begin{array}{l}\text { Dealers in cattle reporting: } \\
\text { Over } 50 \text { percent of purchases } \\
\text { at auctions } \\
\text { Over } 95 \text { pelcent of purchases }\end{array}$ & 11 & 26 & 50 & 5 & 19 \\
\hline at farms & 17 & 69 & 4 & 12 & 15 \\
\hline $\begin{array}{l}\text { Dealers in sheep and lambs } \\
\text { reporting: } \\
\text { Over } 50 \text { percent of purchases } \\
\text { at auctions } \\
\text { Over } 95 \text { percent of purchases }\end{array}$ & 5 & 2 & 61 & 12 & 25 \\
\hline at farms & 20 & 38 & 41 & 20 & 1 \\
\hline
\end{tabular}


stock-marketing agencies. Local deal$\epsilon r s$ operate in a great variety of ways. Some of the earlier trading practices included the selling of livestock to farmers at stipulated prices, with an agreement to repurchase at designated differentials. Some "let livestock out" and agreed to pay so much per head or per pound for gains mads. Others contracted with producers for the delivery of livestock many months in the future, and still others attained control of livestock by financing producers during feeding periods. ${ }^{5}$ These early practices are less important than formerly and primarily apply to dealer-farmer relationships.
Cooperaives: The first marketing agency to encroach upon the operation of local livestock dealers in West Virginia was the cooperative livestock shipping association. Armentrout suggests that dissatisfaction with the dealer system of livestock marketing was one of the important factors contributing to the organization of these associations. It has been indicated that such cooperatives in West Virginia, however, have primarily restricted activities to the handling of lambs. Sales of veal calves and finished cattl $\triangleq$ have never been large. Consequently, most deal-

\section{Table 13-Extent of Livestock Purchases and Sales by Weight and by Head Classified According to Species and Class, Size of Dealers, and Type of Livestock-Producing Area Served, as Reported by 46 Dealers in West Virginia, 1939}

\begin{tabular}{|c|c|c|c|c|c|}
\hline \multirow{2}{*}{ Classification } & \multirow[b]{2}{*}{ Hea d } & \multicolumn{2}{|c|}{ Method of purchase } & \multicolumn{2}{|c|}{ Nethod of sale ${ }^{1}$} \\
\hline & & Weight & Head & Weight & Head \\
\hline & number & percent & percent & percent & percent \\
\hline \multicolumn{6}{|l|}{$\begin{array}{l}\text { Livestock species } \\
\text { and class }\end{array}$} \\
\hline Cattle & 22,227 & 72 & $2 S$ & SS & 12 \\
\hline Calves & 6,932 & 60 & 40 & 98 & $\underline{2}$ \\
\hline Swine & 4,385 & 67 & 33 & 80 & $2 \overrightarrow{0}$ \\
\hline Sheep and lambs & 76,115 & 96 & 4 & 98 & 2 \\
\hline \multicolumn{6}{|l|}{$\begin{array}{l}\text { Size of dealers } \\
\text { Small (Lnder } \$ 50,000 \text { ) }\end{array}$} \\
\hline Cattle & $\tilde{E}, C 02$ & 16 & 54 & 86 & 14 \\
\hline Calves & $2,9=\pi$ & 41 & 59 & 94 & 6 \\
\hline Sheep and lambs & 21,015 & 92 & 8 & 96 & 4 \\
\hline \multicolumn{6}{|l|}{ Large (Over $\$ 50,000$ ) } \\
\hline Cattle & $1 \overline{1}, 225$ & 80 & 20 & 90 & 10 \\
\hline Calves & 3,975 & 81 & 19 & 100 & \\
\hline Sheep and lanibs & 55,100 & 97 & 3 & 98 & 2 \\
\hline \multicolumn{6}{|l|}{$\begin{array}{l}\text { Livestock-producing } \\
\text { area served } \\
\text { Eistern livestock }\end{array}$} \\
\hline Cattle & $\overline{5}, 2 \overline{1}$ & $\$ 1$ & 16 & $\therefore 7$ & 3 \\
\hline Calves & 1,610 & 29 & $\because 1$ & 95 & $\tilde{\jmath}$ \\
\hline Sheep and lambs & 59,680 & 97 & 3 & 97 & 3 \\
\hline \multicolumn{6}{|l|}{ Central lisestock } \\
\hline Cattle & 12,482 & 78 & 22 & $8 S$ & 12 \\
\hline Calves & 2.760 & 77 & 23 & 98 & 2 \\
\hline Sheep and lambs & 13,950 & 93 & 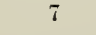 & 100 & $\cdots$ \\
\hline \multicolumn{6}{|l|}{ Daily and general } \\
\hline Cattle & $4, \pm 70$ & 43 & 57 & 82 & 18 \\
\hline Calves & 2,562 & 60 & 40 & $9 \bar{S}$ & 2 \\
\hline Sheep and lambs & 2,185 & 79 & 21 & 89 & $1 \overline{1}$ \\
\hline
\end{tabular}

${ }^{1}$ To the extent that dealers fatten livestock themselves, or keep feeders and breeding animals as a trading proposition, the numbers purchased and sold are not identical. For practica! purposes, however, these numbers may be considered the same.

5For a detailed description of the early marketing practices of local dealers, see w. IT. Armentrout, Efficiency of Cooperative Livestock Shipping Associations in West Virginia, W. Va. Agr. Exp. Sta. Bul. 249, 1931, pp. 10-12. 
ers handling cattle for slaughter have experienced only limited competition from these associations.

Auctions: Since auction markets furnished additional outlets for both farmers and local dealers, it is apparent that auctions are in position tc influence significantly the methods of operation followed by local dealers. Livestock auctions have brought with them considerable decentralization of the marketing functions. They enabled those dealers who were willing to make adjustments in operating methods to correspond with changing market conditions to take "a new lease on life." Some local dealers have developed close working agreements with livestock auctions, sometimes to the extent of becoming part owners of auctions. These dealers report that frequently they have been forced to take up "the slack" at auctions, at times of limited buying competition.

Even more than cooperative livestock marketing associations, auction markets, to an appreciable extent, have superimposed themselves on the dealer system of livestock marketing. Dealers no longer enjoy the monopolistic position in livestock marketing that they did a quarter of a century ago. For some dealers these changes have resulted in the farm being replaced by the auction as the principal source of supply. In other instances auctions have replaced terminal agencies as the immediate destination for livestock handled by local dealers. In effect, then, two important additional types of dealers are developing because of the influence of auction markets. These are: (1) dealers that buy in the country and sell at auctions, and (2) dealers that buy at auctions and sell through terminal market agencies.

There are many evidences that close working relationships have developed between dealers and auction markets. During 1939, dealers reported visiting on an average four different auctions each in their business operations. Local dealers usually visited each auction several times per year. The average number of yearly visits per auction for 45 dealers was reported at 56. Approximately two-thirds of the visits to auction markets resulted in some kind of purchase by local dealers. On the basis of available data, this meant that average purchase per sale by local dealer's amounted to $\$ 136$ each.

About as many dealers sold through a u ctions as purchased through them. Only about one-tenth as many horses, one-half as many cattle and calves, about the same number of sheep and lambs, and three times as many swine were sold through auctions by dealers as were purchased by them. Therefore, the average size of sales per visit was scmewhat less than average purchases.

As to trends in purchases and sales through livestock auctions, dealers indicated that dealings with auction markets were increasing. Out of 35 dealers reporting, 12 reported no significant trend in their auction business during the three years 1936 to 1939, 15 an increase, and 7 a de. crease. Those doing less business through auctions in 1939 than in 1936 reported that such items as decrease in business, increased competition from packers, and questionable business practices at some auctions were the principal reasons for this trend. Those doing more business through auctions reported that they accounted for this trend primarily because of improved business practices at many auctions, better and more uniform prices, an in- 
creased number of auctions, and the convenience of using them as outlets for odd and off-quality lots of livestock.

Local dealers were asked to indicate criticisms, strong points, and possibilities for improvement in auction-market operation. Because of the fact that livestock auctions offer direct competition to many dealer's, it is recognized that some bias may exist in the answers obtained to these questions. Furthermore, the views of dealers vary considerably, depending upon the extent to which auctions are used as a source of supply or as an agency to sell through. The views expressed, however, should be of assistance to auction operators in enabling them to make adjustments that may help them improve their relations with both farmers and dealers.

Criticisnis of trading at livestock auctions as expressed by Iocal dealers included the following:

\section{Types of criticism}

Low and fluctuating prices Limited demand for livestock handled

Spread of disease

Unsatisfactory operating practices

Lack of buying competition

Business ethics

Waste of farmer's time

Excess number of auctions

Unclassified

Further attention will be given to these considerations in the section relating to livestock auctions. Those acquainted with auction methods of operation, however, are aware of the difficulty of balancing an adequate supply of livestock with the necessary number and kind of dealers, and the corresponding influence that such a situation can have on price. The inadequate sanitary precautions taken at some markets, coupled with questionable operating and managerial ethics, are important items influencing the relationship of some dealers to auctions.
Those dealers that are disturbed $\mathrm{by}$ the quality of livestock available at auctions mention as serious market problems such items as the fact that most auctions do not have suit. able buyers for finished cattle and the fact that they encourage farmers to sell their stock too soon and in an unfinished condition. While there is justification for these criticisms, it should be kept in mind that part of the difficulty may be due to the fact that dealer's may not be aware of the gradual trend toward dairying in some parts of the state and to the fact that under such conditions, calves and cull cows are the principal kinds of cattle available. While this trend may be in accordance with good farm-management practices, it does serve to limit the number and quality of livestock available for dealers. In other instances, an appreciable portion of livestock sold at auctions comes from the self-sufficing and general farms of the state, and quality of pasture and management and feeding practices on these farms often are not conducive to the production of highquality finished livestock. With respect to operating practices of livestock auctions, dealers at times expressed dissatisfaction with grading or sorting, weighing, and reported collusion on the part of buyers.

The strong points of trading at livestock auctions as indicated by local dealers were reported as follows:

\section{Strong points}

Readily available market Price advantages

Increased bargaining power Good market for cull stock

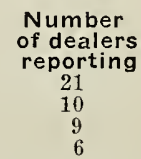

These factors relate largely to advantages for farmers. Many dealers were frank to admit that auctions benefited farmers even though it was difficult to obtain a satisfactory volume of livestock and that auctions were responsible for increasing the 
price they were forced to pay farmers. Of most importance was the fact that auctions furnished a ready market. Farmers in need of money could sell one or two head of livestock at any time. Most farmers, they point out, have ready access to one and, in some instances, three and four auctions a week. Formerly they often were at the mercy of one or two dealers who usually called not over three or four times a year. This applies particularly to smaller farmers who frequently were not acquainted with market values and who marketed only a few head a year. This situation helps explain the tendency for dealer prices to be relatively high with auction competition. Since an appreciable portion of the lower grades of stock are killed locally, it is evident that prices for such stock are relatively higher than at terminal markets, largely because of savings in transportation. One dealer stressed the educational value of auctions, indicating that they enabled patrons to observe at first hand the quality-price relationship.

That suggestions for improvement of trading practices are closely related to weaknesses of livestock auctions may be seen by examination of data relating to the suggestions offered for improvement, reported as follows:

\section{Suggestions for improvement}

Better business ethics Improve operating practices Better sanitation practices Fewer auctions

Handle better livestock

Increase volume of business

Unclassified

Various marketing practices of auction employees have caused considerable dissatisfaction among consignors. For instance, to the extent that some auctions deviate from a strictly brokerage basis and permit employees to trade in livestock, it is impossible to avoid dissatisfaction and to give definite assurance that

every consignor receives equal treatment. This situation suggests the direction in which needed improvements might be made.

Farmers: Because of the close relationship existing between local livestock dealers and farmers, those farmer's furnishing information for this study were asked to express views regarding their experience in trading with local dealers. Of the 626 farmers reporting information concerning marketing agencies, 50 percent reported sales to local dealers, and 7 percent, purchases from local dealers. They were asked to єxpress views regarding criticisms and strong points of this marketing agency.

Criticism of trading with dealers were indicated by 202 producers. In the order of importance they were:

Types of criticism

Poor prices

Poor market connections

Business ethic:;

Unclassified

Suggestions for improvement in market operations of dealers were made by 54 producers. These varied all the way from suggestions for a greater number to fewer dealers and auctions. The relatively small numher of farmers offering suggestions and the conflicting views expressed indicate that the proportion of producers who have seriously attempted to think through the livestock-marketing problems confronting $\mathrm{t} h \mathrm{~h} \mathrm{~m}$ was very small. As reported by 549 farmers, strong points of trading. with local dealers were listed as follows :

\section{Strong points}

Less expense

Saves hauling and trucking

Farmers need not leave farm

Know prices at time of sale

Satisfactory price

No shrinkage

Less risk

Opportunity to bargain

Dealer intezrity

No grading

Unclassified

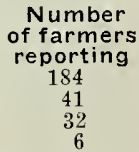
(n)

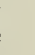

(n)

(n)

(n)

(n)


Most of the strong points listed for trading with local dealers centered about matters of marketing expense and convenience. For example, 164 farmers indicated that less expense was involved in trading with livestock dealers than other market agencies. Farmers should be cautioned, however, to realize that, just because there is no cash or out-ofpocket cost, this should not be interpreted to mean that such costs do not exist when they trade with dealers. Those costs are just as real even though expenses are neither itemized nor directly felt. The farmer seeks the greatest net returns which take into account gross returns as well as marketing expense.

From the standpoint of convenience, two factors are important. First, since most livestock dealers operate trucks of their own they can save farmers the necessity of hauling livestock or of arranging with commercial truckers to perform this service. Secondly, trading with dealers has the advantage of not requiring farmers to leave the farm to deliver livestock. This can result in a considerable saving of time as well as money. Another factor receiving considerable comment by farmers was the fact that the sale price of livestock was known on the day of the sale.

While some of the strong points given by farmers for trading with livestock dealers were not mutually exclusive, they at least serve to indicate the trend of farmer thought and to suggest possible services and methods of operation that should receive the consideration of all marketing agencies, particularly those farmers' cooperative livestock marketing associations that might consider extending service to many of the smaller farmers in the state.

Comparison of strong points and criticisms of trading with local dealers, as advanced by farmers, indicates considerable variation of opinion, particularly with respect to prices. That poor prices was the main criticism of local dealers and that satisfactory prices was one of the principal reasons given for trading with such dealers suggests that wide variations exist in the prices they pay. It is quite likely that this situation also indicates a decided lack of market information or inability to apply and interpret available information on the part of a large proportion of the farmers doing business with local dealers.

Terminal Commission Men: Some of the more recent practices that have been developed by local livestock dealers apply to their relationship to terminal commission men. With the development of good roads and the resulting growth of trucking operations, many dealers have changed their methods of operation considerably. Since livestock no longer "just had to go to terminal markets," commission men in these markets were forced to go after business. By financing local dealers in the purchasing of livestock and by aiding them in the purchase of trucks, many terminal commission agents have developed close operating relations with dealers. By these methods, they have assured themselves of a larger amount of livestock than they could otherwise obtain. Some commission agents have standing agreements to take all the livestock that dealers can deliver. The established relationship of local dealers with terminal commission agencies differs from the relationship with auctions in that terminal agencies serve only as a sales agency while auctions may serve as an agency through which to sell or buy. The terminal commission men who have established 
business relations with local dealers primarily include those at Pittsburgh and Baltimore and to a lesser extent Lancaster, Pennsylvania; Columbus and Cincinnati, Ohio; and Jersey City, New Jersey.

While eight local dealers reported no sales through terminal commission men, the distribution of 21 dealers according to the number of sales in 1939 was reported as follows:

Number of sales

10 or less

$11-20$

$21-30$

31 and over

Three factors are primarily responsible for the favor which commission men enjoy with local dealers. These are: (1) usually better and more stable prices; (2) a larger number of buyers, which furnishes an outlet for a greater number and more grades of livestock than auctions can handle without depressing prices; and (3) a broader market, which enables dealers to sell all grades of livestock.

\section{MARKETING PRACTICES}

Dealers were asked to express opinions concerning various marketing practices. In general, they showed close acquaintanceship with such practices as grading and weighing.

With respect to grading, a few dealers believed that marketing agencies should extend this service to include grading of beef and feeder cattle as well as sheep and lambs. Five dealers volunteered their opinion that grading was closer and more accurate at cooperative associations than at auctions. Most dealers were well acquainted with the grading methods carried on by the various marketing agencies.

While most dealers expressed the view that weights were reasonably satisfactory, a few were impressed by the large number of so-called "mistakes" corrected at auctions. Other dealers objected to the practice of "filling" stock and expressed interest in having auctions work out means whereby livestock would be weighed "out" rather than "in." Some believed that this practice, combined with better facilities for handling loads of livestock, would do much to stabilize shrinkage or drift.

\section{MARKET NEWS}

Local dealers report that they hive utilized such sources of market news as the radio, newspaper, commission-house reports, packer and private market services, and auction, state, and federal market reports. The extent to which each is used depends upon the type of trading activities carried on by dealers and upon established relationships with various marketing agencies. Radio and newspaper reports are received daily, and most auction and commission-house reports are obtained weekly. Auction reports usually relate to prices paid and volume received. Order buyers frequently get telegraphic market information from terminal agencies. The various sources of market news obtained by dealers and the rank, according to importance, given each are shown in Table 14. Those dealers obtaining information from commission-houses, packers, and auctions usually obtain such information from more than one agency.

Market reports of terminal agencies (either commission-houses or packers) and of livestock auctions were used by most dealers in establishing a basis for determining price quotations. As would be expected, market value was largely determined for dealers by the agencies serving as their market outlets. Some dealers indicated that the trend and 
character of auction prices were given first consideration in determining the prices they would pay. A large number of dealers reported that they considered information from commission houses the most important in determining pricas. Such information was obtained from regular reports, or supplemented with telephone calls or wire communications.

\section{TRUCKING}

With the development of improved roads, the growth of livestock auctions, and the decline in rail service, trucking has become an important adjunct of livestock dealers in their methods of operation. Usually, dealers restricted trucking activities to handling the livestock which they purchased or sold. In some instances, however, dealers have engaged in commercial trucking.

Thirty-three of the 46 dealers interviewed reported owning 44 trucks. Further examination showed that the smaller dealers were more likely to own trucks than the larger ones. Of the 27 dealers doing less than $\$ 25,000$ of business annually, 23 owned 29 trucks, while of the 19 doing over $\$ 25,000$ of business annually, 10 owned 15 trucks.

General farming activity as well as commercial trucking may help to give some of the smaller dealers more complete use of trucking facilities. It does seem significant, how- ever, that annual livestock purchases per truck owned were $\$ 7,900$ per truck for the small dealers and $\$ 31,000$ for the large dealers. This suggests higher operating expenses for smaller dealers, less profit, or lower prices for producers selling to them. Of the dealers reporting the use of trucks, 29 indicated that the majority of the livestock they purchased was moved by their own truck. Others hired trucks either to supplement the operation of their own trucks or to do all of their livestock trucking.

No definite information was available concerning commercial trucking rates for livestock. While there is reason to believe that most trucking hired by dealers was arranged for on a bargaining basis, other arrangements sometimes were made on a per-trip, per-head, per-hour, permile, and per-pound basis. Methods of paying for hauling as reported by 29 livestock dealers in 1939 were as follows:

Method of payment

Bargaining basis

Trip

Head

Hour

Mile

Weight

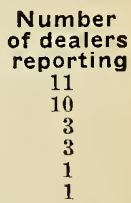

Trucking is one of the principal services that dealers render small farmers. The fact that dealers come to the farm to pick up the stock purchased, thus saving farmers the trouble of either trucking or of making arrangements for trucking,

Table 14-Importance Rank of Various Sources of Market News as Reported by 46 Livestock Dealers in West Virginia, 1939

\begin{tabular}{|c|c|c|c|c|c|}
\hline \multirow{2}{*}{$\begin{array}{c}\text { Source of } \\
\text { market news }\end{array}$} & \multirow{2}{*}{$\begin{array}{l}\text { Dealers } \\
\text { reporting }\end{array}$} & \multicolumn{4}{|c|}{ Rank according to importance } \\
\hline & & First & Second & Third & Fourth \\
\hline & number & number & number & number & number \\
\hline Radio & 37 & 18 & 15 & 4 & \\
\hline Paper & 37 & 7 & 17 & 12 & 1 \\
\hline Commission-house & 28 & 14 & 8 & 5 & 1 \\
\hline Auctions & 14 & 4 & & 6 & 4 \\
\hline State and federal agencies & 3 & & $i$ & 2 & \\
\hline $\begin{array}{l}\text { Packers } \\
\text { Private reporting service }\end{array}$ & $\begin{array}{l}2 \\
2\end{array}$ & $\begin{array}{l}2 \\
1\end{array}$ & $i$ & & : \\
\hline
\end{tabular}


is a decided service to many farmers. It is one of the important factors contributing to the continuation of the dealer system of operation.

\section{REGULATION $^{6}$ AND RECOMMENDATIONS}

There is no state regulation of local livestock dealer operation in West Virginia. While certain regulations governing other market agencies have an indirect bearing on the operation of local dealers, there are no state controls that specifically apply to their operation.

Even though dealers are faced with competition from livestock auctions, packer buyers, and in some instances cooperative associations, the dealer method of operation is well established and may be expected to continue to have a marked influence on the methods of marketing livestock in West Virginia. The influence of such factors as custom, habit, tradition, and convenience is important in determining the manner in which farmers sell and purchase livestock.

In the past, many dealers have rendered valuable service to producers in that they have furnished a market and have aided in financing and transporting livestock. A few, however, have been able to stay in business only because of "sharp practices" in dealing with unsuspecting producers. In the future, it seems that local livestock dealers, if they are to continue in operation, will be forced more and more to give attention to the following factors:

(1) Increased efficiency of operation. This will mean careful consideration of operating costs of various business practices and a reexamination of results obtained from various operating territories covered and agencies dealt with.

(2) Better service to producers. Future success of local livestock dealers will depend more and more upon ability to render service. This may include efforts to acquaint producers with means of producing better livestock, furnishing them with production and market information, furnishing or arranging for needed trucking facilities, and acquainting producers with available sources of production credit in order to enable them to finance livestock production more effectively.

(3) Adjustment of methods of operation to correspond to changes in livestock marketing brought about by the growth and development of other marketing agencies. This involves giving careful consideration to means of improving relations with existing sources of supply and agencies to sell through, and continually being on the alert for additional and better market outlets.

\section{COOPERATIVE LIVESTOCK MARKETING ASSOCIATIONS}

Cooperative marketing of livestock in West Virginia grew out of the informal operation of local lamb pools. Several pools were organized in the state as early as the first World War.
Following these the first formal cooperative livestock marketing association was organized in Wirt County in 1922..$^{\top}$ The Agricultural Extension Division of West Virginia Uni-

\footnotetext{
'The states of Minnesota and Ohio have enacted legislation providing for the licensing of local livestock dealers. Salient features of such legislation include (1) provision for obtaining annual licenses, (2) the keeping of records indicating the nature and extent of business, (3) provisions for testing of all scales used by local dealers, (4) bonding of dealers, and (5) penalties for violations.

Established and reputable dealers, no doubt, would welcome legislation embodying most of these provisions. If properly administered and operated, such controls also would protect farmers against unscrupulous dealers.
} 


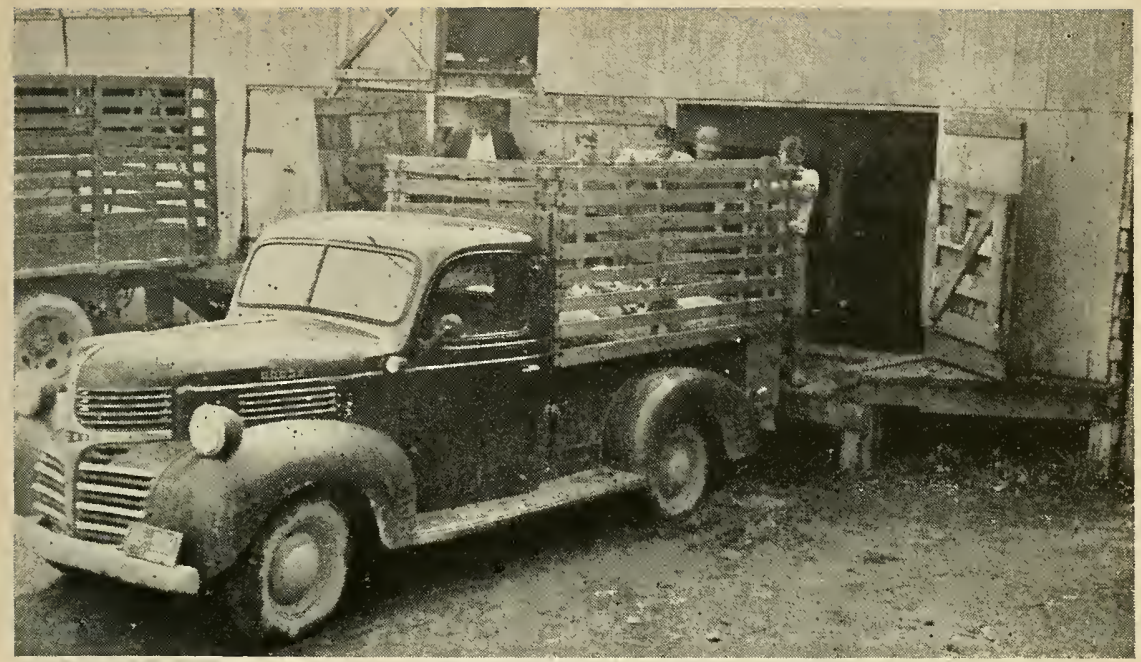

Fig. 13-Receiving Facilities of Cooperative Livestock Marketing Associations in West Virginia

OPERATIONS ARE RELATIVELY SIMPLE. SOME ASSOCIATIONS HAVE THEIR OWN FACILITIES; OTHERS ARRANGE TO USE LIVESTOCK AUCTION FACILITIES

ver'sity and the West Virginia Farm Bureau were largely responsible for the early beginnings of cooperative livestock marketing in the state. ${ }^{8}$

\section{TYPES OF COOPERATIVE LIVE- STOCK MARKETING ASSO- CIATIONS}

The two succeeding decades have witnessed the development of various types of livestock-marketing cooperatives in West Virginia. Changes in methods of organization and operation of established cooperatives also have been numerous. Of particular interest to West Virginia farmers has been the development of local (primarily county), area, ${ }^{9}$ state, and terminal (central-market) cooperatives. This same period has witnessed the modifying influences on livestock marketing of such important developments as improved roads, livestock auctions, direct packer dealing (buying and selling), introduction and growth of lamiband calf-grading at concentration points, and the decline of local or county shipping associations. Attention is here given to general aspects of the growth and development of the various types of cooperative livestock associations that have been organized in the state. (For location

iFor a detailed account of the early history of cooperative livestock marketing in West Virginia, see W. W. Armentloul, Efficiency of Cooperative Livestock Shipping Associations in West Virginia, W. Va. Agr. Exp. Sta. Bul. 249, 1931, pp. 14-20.

${ }^{8}$ Edwin G. Nourse and Joseph G. Knapp, in their book, The Cooperative Marketing of Livestock, indicate that cooperative narketing of livestock in West Virginia developed along lines similar to that in Ohio, where county and state Farm Bureaus in cooperation with the State Extension Division assumed leading roles in livestock marketing (pp. 27-29). They also mention that West Virginia had representation on the Committee of Fifteen, which recommended the olganizaiton of numerous regional producers' associations.

"The term "area" is used in this discussion to describe cooperatives operating in areas of two to eight cunties. In some sections common usage has designated these cooperatives as "regional" associations. 


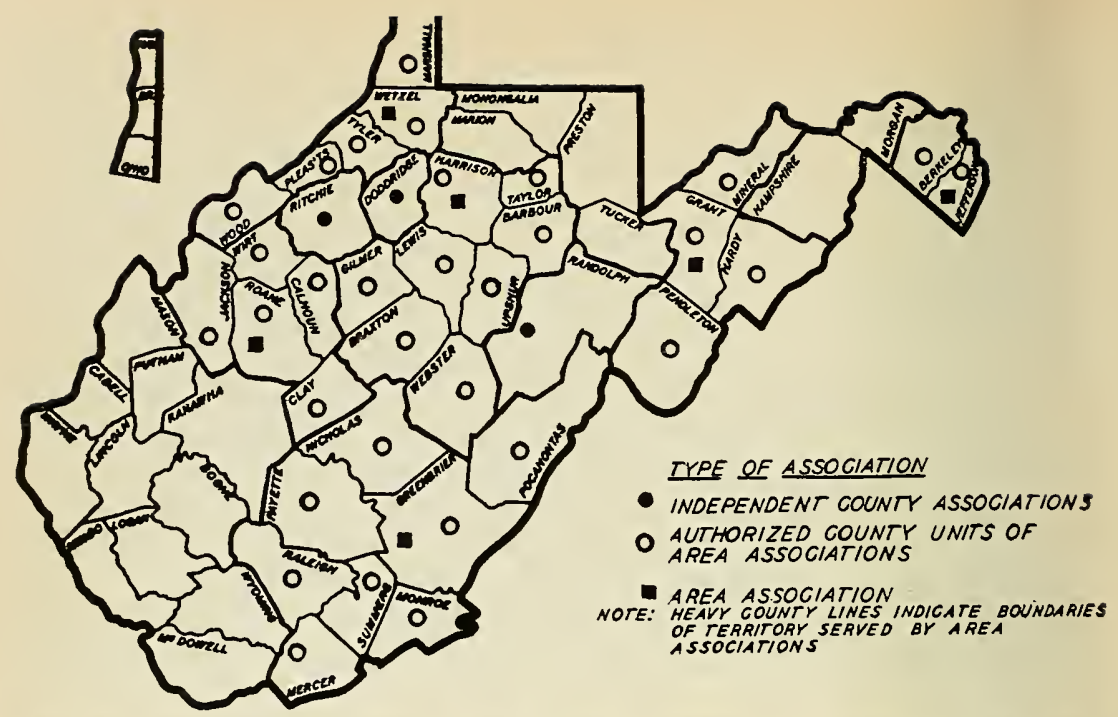

Fig. 14-Location of County and Area Cooperative Livestock Marketing Associations, West Virginia, in 1942

of cooperative associations operating in 1942, see Fig. 14.)

Local Associations: Armentrout found that 21 local marketing associations were organized in West Virginia on a county basis between 1922 and 1929. Of this number, 16 were organized between 1923 and 1925 , inclusive. Seven of the 21 associations organized had become inactive by 1929 . Since then, considerable change has taken place. Two local asscciations operating as county units in 1929 subsequently ceased business operations. However, at least 3 of the associations functioning as county units in 1942 had ceased business operations by 1929 and later were reorganized.

A further development since 1930 has been the organization of 10 local (county) cooperatives on an unincorporated, loosely organized, and informal basis. Few of these associations marketed livestock. They have, however, served as member units of area associations. Beginning in 1930 the function of selling was largely assumed by area associations which were set up in a number of places in the state.

The early associations (established before 1930) did their own selling (either $\mathrm{through}$ cooperative or through private terminal agencies) and took complete responsibility for all problems relating to assembling, method and place of sale, and determination of general operating policies. Primarily because of lack of business, many of the county associations organized after 1930 have laigely functioned as clearing houses for educational efforts in livestock production and marketing. Except for the county members of the Greenbrier Valley Area Association, few of the affiliated county associations maintain shipping points or formal organization.

Area Associations: In 1930, the first of six area cooperative livesiock marketing associations was organized in West Virginia (See Fig. 14). Subsequent dates of organizaticn were, respectively, 1932, 1936, 
and 1938 (three). A number of factors have contributed to the development of area livestock cooperatives. Many of the county associations experienced a noticeable decline in volume of business after 1926 (Table 15). Since 1926, there has been a noticeable increase in the number of lambs handled and a decrease in the number of cattle sold. These facts, combined with improvements in roads, development of trucking, competition from livestock auctions, and direct dealing, all have contributed to the growth of area marketing associations.

Decline in the volume of business conducted by local livestock associations during the period of 1927 1929 was followed by loss of interest in cooperative marketing on the part of many members of county marketing associations. Consequently, business volume frequently did not justify continuation of some of the associations. Establishment of area associations, with concentration of volume at fewer shipping points, enabled farmers in some counties to reduce selling costs and at the same time to avail themselves of the services of a cooperative association -a situation that would not have been possible had they been forced to rely on county associations.

In 1940, livestock sales from seven counties (represented by two independent county associations and two area associations) accounted for approximately 75 percent of all cooperative livestock sales. Concentration of sales in a few counties helps to explain the relatively loose relationship of many of the other county associations to the area cooperatives serving them. The extent to which county cooperatives take an active interest in area association affairs depends upon such factors as the services rendered to producer members, the extent to which county agents work with livestock cooperatives, and the degree to which area associations have taken the lead in acquainting directors and members of county associations with operating practices. In some instances, area associations have wisely undertaken this responsibility themselves. In others they have enlisted

Table 15-Number of Head of Livestock Sold, Gross Sales Value, and Percentage of Gross Sales net to Patrons as Reported by County and Area Cooperative Livestock Marketing Associations in West Virginia, 1924-1942

\begin{tabular}{|c|c|c|c|c|c|c|}
\hline \multirow[b]{2}{*}{ Year } & \multicolumn{4}{|c|}{ Species and class of livestock } & \multicolumn{2}{|c|}{ Gross sales } \\
\hline & Cattle & Calves & $\begin{array}{c}\text { Sheep and } \\
\text { lambs }\end{array}$ & Hogs & Value & $\begin{array}{c}\text { Percentage of total } \\
\text { net to patrons }\end{array}$ \\
\hline & bead & bead & bead & bead & dollars & percent \\
\hline 1924 & 5,201 & 660 & 13,034 & $\ldots$ & 464,972 & 90.4 \\
\hline 1925 & 5,819 & 1,123 & 15,602 & . & 501,588 & 91.8 \\
\hline 1926 & 5,528 & 1,407 & 18,042 & $\cdots$ & 501,501 & 92.0 \\
\hline 1927 & 1,114 & 414 & 16,971 & $\cdots$ & 270,456 & 93.2 \\
\hline 1928 & 1,918 & 614 & 12,293 & . & 288,795 & 92.8 \\
\hline 1929 & 1,433 & 894 & 12,943 & $\cdots$ & 244,227 & 91.9 \\
\hline 1930 & 3,229 & 2,253 & 27,945 & $\cdots$ & 336,609 & 87.4 \\
\hline 1931 & 2,288 & 1,112 & 36,101 & & 307,210 & 86.1 \\
\hline 1932 & 2,827 & 790 & 44,679 & 370 & 316,594 & 85.5 \\
\hline 1933 & 3,748 & 1,004 & 40,956 & 842 & 317,587 & 85.0 \\
\hline 1934 & 3,564 & $\begin{array}{l}1,007 \\
1,246\end{array}$ & 34,251 & 286 & 295,478 & 85.3 \\
\hline 1925 & 1,956 & 878 & 48,963 & 748 & 403,925 & 91.8 \\
\hline 1936 & 2,215 & 2,074 & 56,629 & 1,233 & 517,093 & 93.1 \\
\hline 1937 & 2,162 & 1,639 & 76,614 & 674 & 713,853 & 95.8 \\
\hline 1938 & 1,797 & 2,072 & 62,427 & 621 & 490,778 & 94.3 \\
\hline 1939 & 1,241 & 1,692 & 43,651 & 388 & 333,015 & 94.1 \\
\hline 1940 & 1,300 & 2,344 & 51,671 & 68 & 405,445 & 94.8 \\
\hline 1941 & 1,138 & 2,496 & 48,763 & 35 & 458,488 & 95.8 \\
\hline 1942 & 1,572 & 2,963 & 52,071 & 34 & 703,246 & 96.6 \\
\hline
\end{tabular}


the services of the closely affiliated state and central-market associations for the job. In still others, responsibility for this job has been placed on county agents.

Not unlike county associations, area associations operate on a nonstock basis and carry the provision for equal voting power. Membership was restricted to county units by one area association. All others limited membership to "any person, firm, or corporation engaged in the production of livestock." However, directorship was limited to one or more directors from specified counties. Those directors were either elected at large by all farmer members, or, in the case of one cooperative, it was provided that directors of county units elect the directors for the area association. One of the larger area associations provided for one vote per member county with additional provision for one extra vote per county if sales during the previous year exceeded $\$ 20,000$.

Facilities owned by local associations usually consisted of yards and scales. In some instances, however, arrangements were made with auction companies for the utilization of needed facilities.

The chief function of area associations relates to the determination of general operating policies, including the hiring of managers and the fixing of their commissions. The managers are given the right to employ assistant managers, usually on a county basis for member associations. The bylaws also provide that county associations may market wool for members as a unit of the West Virginia Wool Marketing Association.

Area and independent county associations are required to take out membership in the West Virginia Livestock Marketing Association (a state association). The life membership fee in the state association is five dollars. The area cooperatives also agree to pay the state association a fee of one cent per 100 pounds of live. weight for all livestock they handle. The area and independent county associations are $r=$ presented on the board of directors of the state association either by a member of the board of directors (usually the president) or by the manager. Further consideration will be given to both local and area cooperative associations in the section dealing with market operations.

State Association: The first livestock cooperative to operate on a state basis was the West Virginia Cooperative Livestock Shipping Association, Inc. This association was organized in 1924 and reorganized in 1930 as the West Virginia Livestock Marketing Association. While this association does no livestock business itself, it does assume the responsibility for determining general policies and for directing business procedures of member associations (county and area). It requires that the constitution and the bylaws of member associations meet established provisions. The association reports that it carries on its educational work through field work and through the awarding of various scholarships. Scholarships include trips to packing plants and to livestock shows. The state association also has taken part in financing the purchase of scales ard other necessary equipment for county and area associations that market livestock direct. Other activities include financing of dinners and banquets for county and area livestock- and wool-marketing associations as well as payment of lamb graders of the State Department of Agriculture who were employed by some member associations.

Terminal-m a $\mathbf{r}$ e $\mathbf{t}$ Associations: Terminal-market associations have come to play an increasingly im- 
portant part in the marketing of West Virginia livestock. The Producers Cooperative Commission Association (Pittsburgh branch) serves cooperative livestock associations in West Virginia. Headquarters are at Columbus with branches at Pittsburgh and other points. The association was organized in August, 1923, and the Pittsburgh branch in October, 1923. This association did not handle livestock on an extensive scale at Pittsburgh until 1928. Supplementing the activities of the Producers Cooperative Commission Association, the Eastern Order Buying Company was organized as a subsidiary in 1935 to handle direct marketing activities.

Membership in the Producers Cooperative is limited to producers of livestock. It operates without stock or membership fee, and membership carries no personal financial responsibility. In 1942 the association reported 55,320 patrons, 13,555 of whom were patrons of the Pittsburgh branch, of which 3,569 , in turn, were member patrons from West Virginia.

The association reports that its territory of operation is districted for the selection of directors. One or more directors, selected in proportion to the business transacted, represented 11 marketing territories in 1942. In addition the Ohio Farm Bureau, the Indiana Farm Bureau, and the Ohio State Grange nominate one director each. West Virginia has two representatives on the asscciation's board of directors.

The existing relationships between local and central-market associations are much closer than they were during the first years that local cooperative livestock associations were in operation. Then, many county associations sold considerable livestock to old-line or private commission men at central markets. In fact, during the period 1924-1927, livestock cooperatives in West Virginia handled nearly twice as many animal units of livestock as did the Pittsburgh branch. During the period 1927-1940, however, cooperative marketing associations in West Virginia handled only one-sixth as many animal units as did the Pittsburgh branch, and practically all the livestock they marketed were sold through central-market associations -either as terminal or direct sales.

Business operations have been directed along the following lines: (1) selling (terminal market and direct), (2) owning and operating stockyard facilities, (3) furnishing feeder stock, (4) financing and purchasing of feeder cattle, (5) financing livestock truckers, (6) furnishing market information, and (7) furnishing field workers and funds for educational and promotional work.

\section{MARKETING OPERATIONS}

This section deals with the market operations of cooperative livestock associations in West $\mathrm{Virginia}$ (county, area, and state) and with the terminal-market agencies outside of the state that have served cooperatives and livestock farmers.

County and Area Cooperative Livesiock Marketing Associations: Market operations as they relate to local and area associations give attention to such items as: (1) nature and extent of cooperative livestock marketing; (2) relationship of the Eastern Order Buying Company to West Virginia associations; (3) operating comparisons giving consideration to commission charges, grading activities, and business records and audits; (4) market territory; and (5) educational and field work.

Nature and Extent of Cooperative Livestock Marketing: Data presented in Table 15 indicate that veal calf sales, except for the years of 1930 
and 1931, were not particularly significant until 1936. Since then, calf sales have increased considerably and in 1942 reached an all-time high of 2,963 head. In contrast, the number of cattle marketed has shown a marked decrease. From a yearly average of approximately 5,500 head for the period 1924-1926, numbers handled decreased to a yearly average of about 1,300 head for the period 1939-1941, and even in 1942 only 1,572 head were handled.

No marked increase was noticed in the number of sheep and lambs marketed until 1930. At that time, business more than doubled over the previous year, and thereafter it showed a more or less regular increase until 1937, when an all-time high of 76,614 head were handled. Since then, the general trend has been downward and in 1942, 52,071 head were marketed. The volume of hogs handled never was significant - reaching a high of 1,233 head in 1936 and a low of 34 head in 1942 .

Yearly sales varied from a low of $\$ 244,000$ in 1929 to a high of $\$ 714$,000 in 1937. Variations in sales are explained, in part, by changes in livestock prices and, in part, by changes in the physical volume of livestock handled. Changes in the percentage of total gross returns going to patrons were largely accounted for in a shift to direct marketing, which has eliminated much of the yardage and feed costs formerly connected with livestock marketing.

The relative proportion of cattle to all livestock handled, when expressed in animal units, has shown a more or less continual decline-from 82 percent in 1924 to 26 percent in 1942 (Fig. 15). ${ }^{10}$ In contrast, sheep and lambs accounted for but 14 percent of all animal units marketed in

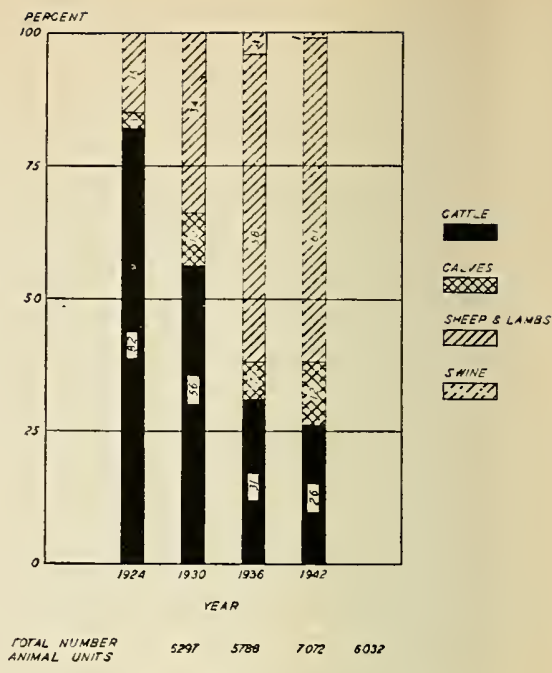

Fig. 15-Trends in Percentage Distribution of Total Animal Units of Various Species of Livestock Handled by County and Area Cooperative Livestock Marketing Associations in West Virginia for Selected Years in the Period 1924-1942

1924, while in 1942 they accounted fcr 62 percent. Hence the relative importance of cattle as compared with sheep and lambs has been more or less reversed during 19 years of operation as the major item in the business of West Virginia cooperatives. Calves, although showing a somewhat irregular trend, accounted for 12 percent of all animal units marketed in 1942.

Considerable difference in the nature and extent of the business conducted by various local and area associations may be noted from 1942 sales data. Of the 14. associations (county and area) maintaining separate accounts in 1942,8 reported handling cattle. Only 3, however, handled over 100 head during 
the year. The number handled per asscciation ranged from 20 to 609 head. Only 3 associations marketed hogs and in no instance was the number sold important. Fourteen associations marketed veal calves -the number ranging from 2 to 635 per association. Six associations handled less than 100 calves, 2 between 100 and 250 , and 6 over 250 head. All associations $\mathrm{h}$ a $\mathrm{n} \mathrm{d} \mathrm{l} \mathrm{e} \mathrm{d}$ lambs-the number ranging from 159 to 9,737 per association. Three associations handled less than 1,000 , 7 between 1,000 and 5,000 , and 4 over 5,000 head each.

In 1942 , yearly sales per association varied from $\$ 5,399$ to $\$ 166,568$. Five associations reported sales of less than $\$ 25,000$; four, sales ranging from $\$ 25,000$ to $\$ 50,000$; three, sales of $\$ 50,000$ to $\$ 100,000$; and two, sales of over $\$ 100,000$.

There seems to be little relationship between size of association and percentage of gross receipts returned to producers. All associations operate on the commission basis. Those that market a significant number of cattle through terminal yards reported a somewhat higher than average marketing cost because of yardage and feeding expenses.

About 15 percent of all lambs sold in the state in 1940 moved through cooperative channels. For the 26 counties served by county and area associations it is estimated, by the state association, that the proportion of total lambs marketed that were handled by county and area cooperatives varied from less than 2 percent in Nicholas County to a high of 41 percent in Roane County. Less than 10 percent of all lambs produced were marketed cooperatively in 9 counties, 10 to 20 percent in 11 counties, and over 20 percent in 6 counties. This suggests that if county and area cooperatives are to improve their position and to qualify as "pacesetters" among marketing agencies in the livestock business, it will be necessary for most of them to increase the amount and kinds of livestock marketed.

Relationship to the Eastern Order Buying Company: The operations of this concern are particularly important as they relate to the marketing of lambs in West Virginia. ${ }^{11}$ In 1939, for example, West Virginia lambs and calves, respectively, accounted for nearly two-thirds and one-third of the total business of that company, and about 95 percent of all sheep and lambs marketed cooperatively in West Virginia were handled through this agency. Approximately two-thirds to three-fourths of the veal calves marketed cooperatively also moved direct. All livestock sold through the Eastern Order Buying Company was shipped from points in West Virginia to points designated by the packer-buyer. The bulk of these shipments were made to New York, New Jersey, and Massachusetts.

Operating Comparisons: It is not possible to make the usual operating comparisons of financial statements for county and area cooperative livestock marketing associations. This is accounted for by such factors as restrictions imposed by officers of the state association on the use of cer. tain financial records, difficulty in reconciling yearly financial statements, and inclusion of items other than those pertaining specifically to livestock marketing in the financial records. Consequently this study does not attempt any consideration of operating efficiency of livestock cooperatives as compared with other marketing agencies. Attention, however, is given to some items that

11During recent years the Producers Cooperative Commission Association, Inc., through the Eastern Order Buying Company inaugurated the practice of buying cattle direct in the country. 
have considerable bearing on operating performance - particularly comnission charges, grading activities, and business records and audits.

(Commission Charges) In general practice the following commissions were charged patrons of local associations. Commissions for s a les through the Pittsburgh branch and for managers of local associations were 14 cents each per 100 pounds of livestock. Supplementary charges varying from 2 to 12 cents per 100 pounds were made in addition to these items. These charges were designed to furnish funds for general operating expenses and to meet obligations for the payments on yard and scale facilities.

Managers of area associations usually employ assistant managers (in the various counties served by the association). Commissions to assistant managers generally ranged from 6 to 10 cents per 100 pounds of livestock. These were paid by managers out of their 14-cent commission. The manager also was expected to pay all necessary labor costs out of his commission. State association dues were 1 cent per 100 pounds.

Each association maintained its own insurance fund. This was accumulated by deductions which averaged around 5 cents per 100 pounds of livestock. In actual practice, however, claims were negligible, and the funds collected were used largely for general operating expenses, educational and field work, and the payment of obligations on facilities.

The distribution of managers, according to the yearly commissions received, was as follows for the years 1938, 1940, and 1942:

\begin{tabular}{cccc} 
Manager's yearly & \multicolumn{3}{c}{ Years } \\
commission & 1938 & 1940 & 1942 \\
dollars & number & number & $n u m b e r$ \\
300 and under & 6 & 6 & 6 \\
$301-600$ & 4 & 5 & 3 \\
$601-900$ & 2 & 3 & 3 \\
901 and over & 2 & $-\frac{2}{14}$ & $\frac{1}{14}$
\end{tabular}

The relatively low income of managers of livestock associations-especially when consideration is given to payments to assistant managers ard helpers-suggests one of the more important problems facing livestock cooperatives in the state. The smali proportion of livestock handled (either because of the limited livestock in the community or because only a small proportion moves through cooperative channels) means that the compensation of managers is so low that in many instances capable persons cannot be attracted to these important positions.

Total commissions taking the form of various charges were reported at between 35 and 40 cents per 100 pounds for each association. In actual practice, however, somewhat greater variations existed. Expressed in costs per lamb, these charges averaged about 25 cants per head. These costs, however, do not represent the total expenses of marketing lambs, although they do account for total cash outlays of the associations. Non-cash expenses of cooperative livestock marketing relate to such items as: (1) during recent years, the authorized services of a county agent for the purpose of preparing yearly audits, and (2) especially during the earlier years of operation, the practice of some county agents of rendering such services as marking and weighing livestock and, through their offices, soliciting livestock and assisting with clerical work. It is encouraging that a few associations are gradually reaching the point where they assume responsibility for the performance of some of these tasks. ${ }^{12}$

(Grading Activities) All lambs are graded upon arrival at local assembly points. The Pittsburgh branch of the Producers Cooperative Commission Association furnishes graders for all county and area associations 
except those operating in the Greenbrier and South Branch Valleys. Grading for these associations is done by the State Department of Agriculture. The West Virginia Livestock Marketing Association paid the State Department of Agriculture for the performance of this service for these associations. A charge of 2 cents per lamb and 10 cents per calf was made for grading. The practice of selling lambs according to grade was inaugurated by livestock-marketing associations in 1935.

In cooperation with the Pittsburgh Producers, six grades of lambs were established in accordance with tentative federal standards. These grades were copyrighted and include: choice (blue); good (red); medium (yellow down the back); plain (yellow across shoulder); cull (yellow across hip); and skip (yellow dot on hip). These various color markings have been devised by graders in order to identify lambs according to established grades. No set or established price differential was maintained throughout the season. However, the usual differential has been as follows: choice over good, 75 cents to $\$ 1.25$ per cwt.; good over meduim, about $\$ 1.50$; medium over plain, around $\$ 2.00$; and plain over culls, $\$ 1.50$ to $\$ 2.50$. Somewhat smaller differentials existed for calves. As reported for 1940 , calf differentials per 100 pounds were as follows: choice over good, $\$ 1.00$; good over medium $\$ 1.00$; medium over plain, $\$ 1.00$; plain over culls, $\$ 1.50$ to $\$ 2.00$.

Data shown in Table 16 indicate that the proportion of choice lambs marketed by cooperative associations has varied from a high of 29 percent of all lambs in 1938 to a low of 16 percent in 1940. Furthermore, the proportion of good lambs, except for 1941 and 1942 , was approximately 30 percent of the total. During the same

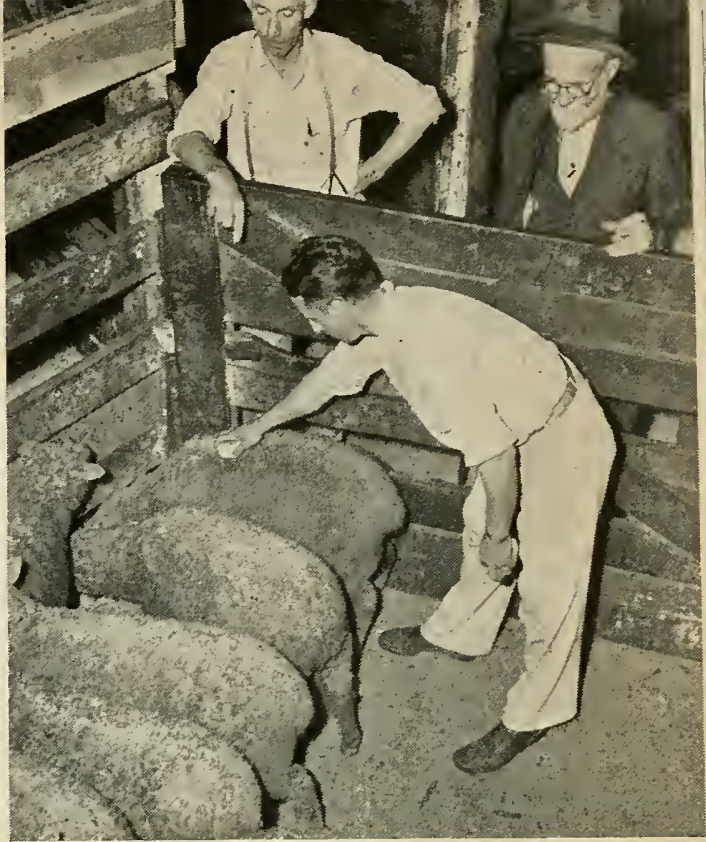

Fig. 16-Grading Lambs at Cooperative Livestock Marketing Yards

\section{COOPERATIVE ASSOCIATIONS HAVE TAKEN THE LEAD IN ENCOURAGING GRADING IN WEST VIRGINIA}

period the proportion of medium lam s accounted for between one-fifth and one-third of all lambs marketed. Lambs graded as plain, cull, or skip have accounted for between onefourth and one-seventh of total sales. (For further details see Fig. 17.)

A combination of factors appears to be responsible for the variation in lamb grades. These include: (1) a tightening up on grades since the inauguration of the grading service, (2) unfavorable seasons for lamb production, and (3) shifts in the proportion of lambs handled from various producing areas. It is impossible to determine the relative significance of each factor as it has influenced lamb grades.

(Business Records and Audits) It has been indicated that little information is available that will serve 
as a basis for making financial comparisons of the county and area cooperative livestock marketing associations. In common with most livestock cooperatives, associations in the state have operated with a minimum amount of capital. Investments in such facilities as yards and scales are relatively small. Associations have not felt the need to accumulate any considerable amount of funds for reserve capital. At least no aggressive steps have been taken in this direction.

Such data as are available, however, indicate the need for critical examination of accounting and auditing policies. ${ }^{13}$ Area associations have wisely provided for the bonding of all officers handling funds and for the auditing of accounts. Failure to insist that auditing be done by certified public accountants, however, has prevented associations from obtaining adequate data for the determination of business policies. Some of the associations report various financial items that relate to the marketing of wool and to other items. To increase the usability of business records, it would be helpful if the annual accounts were set up so that separate records were kept for each activity as well as for different species of livestock. If this were done, associ- ations would be better able to evaluate performance and to establish a sound basis for determining future policy.

Further suggestions for improvement of business records include: (1) adoption of uniform financial policies with respect to collection of membership fees and purchasing of needed supplies, (2) use of established credit agencies to finance associations, and (3) establishment of uniform depreciation charges and handling of such charges as a current operating expense. The state association is in position to encourage county and area associations in establishing sound accounting practices.

Market Territory: The number and kind of livestock marketed through the Pittsburgh Producers from various counties in West Virginia are shown in Table 17 . With the exception of sheep and lambs, and to a limited extent calves, practically all livestock sold through the Pittsburgh branch came from counties in the northwestern part of the state. Not all livestock marketed from these counties is sold through the county and area associations operating in the state. Comparison of data presented in Tables 17 and 15 indicates that the proportions of livestock sold through the Pittsburgh branch that

\section{Table 16-Percentage Distribution of Lambs According to Grades Marketed, As Reported by County and Area Cooperative Livestock Associations in West Virginia, 1938-1942}

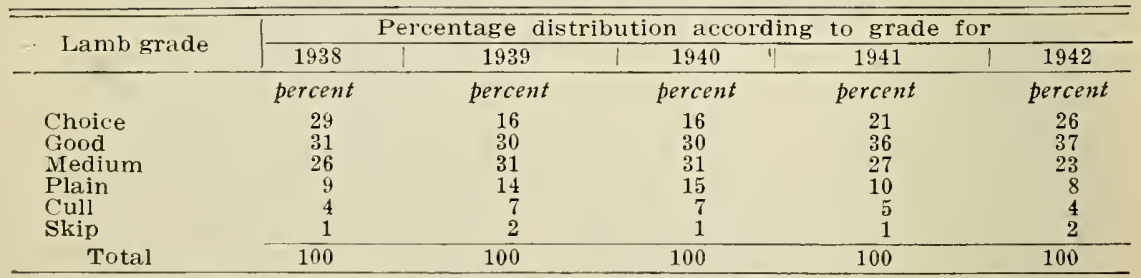

${ }^{13}$ Ir. commenting on the need for auditing, the Farn Credit Administration reports"There is a tendency at times to try to economize on auditing expenses by having a limited audit made or by employing someone who is willing to nake the audit for a small fee. Usually such audits are worthless because little more is done than to copy the bookkeeper's records. It calnot be too strongly urged that audits should be thorough and made by competent persons." (p. 11, Circular E-20). 


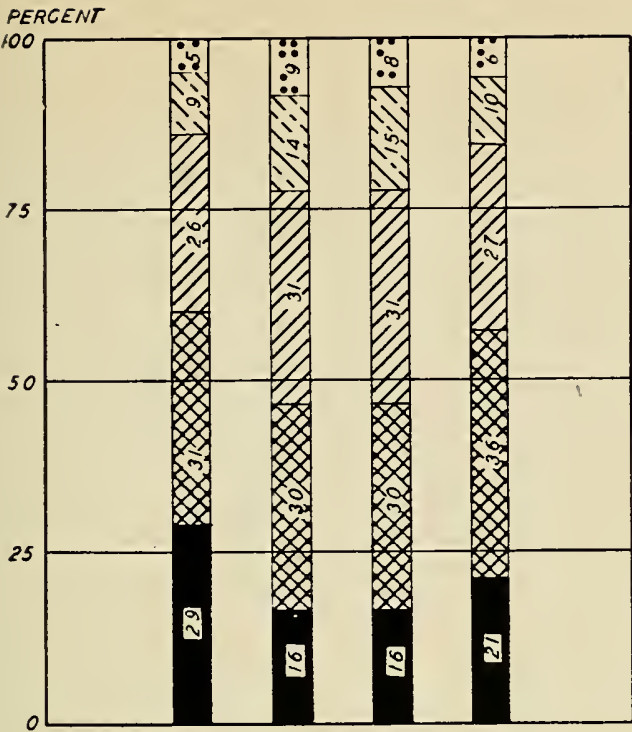

SALES THAOUGH AUCTIONS

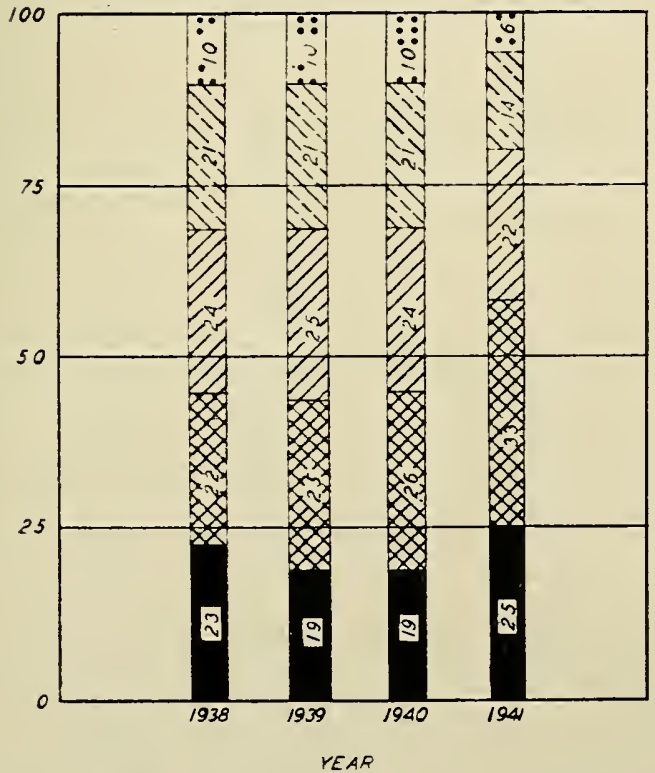

\section{CHOICE}

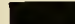

GOOD

$\infty \times \infty$

MEOIUM

PIDI

PLAIN

III]

CULL S SKIP

:i:?:?

Fig. 17-Percentage Distribution of Lambs According to Grade, as Reported by Cooperative Livestock Marketing Associations and Auction Markets in West Virginia, 
were marketed by county and area associations in 1942 were 80, 93, 94, and 8 percent, respectively, for cattie, calves, sheep and lambs, and hogs. The remainder was received at Pittsburgh direct from individual producers.

A considerable proportion of the livestock other than sheep, and lambs that is marketed cooperatively enters Pittsburgh by truck. It is reported that two-thirds of the cattle, threefourths of the calves, and almost all of the hogs move to the primary market by truck. In recent years the more aggressive cooperative managers have arranged transportation for patrons without trucks.

Educational and Field Work: With the assistance of the Pittsburgh branch of the Producers Cooperative and the West Virginia Livestock Marketing Association, a limited amount of educational and field work has been conducted for county and area livestock marketing cooperatives and for their member patrons. The general practice is for the Pittsburgh branch to furnish funds to the state association. These funds are supplemented with unexpended insurance funds of county and area associations. No clear-cut program of field and educational work, however, has been undertaken by local associations. The grading of lambs, market-news broadcasts, and the rendering of special service for patrons constitute the direction of these efforts. Such matters as organization set-up, membership relations, and the development of membership responsibility, are considerations that seem to be in need of further attention.

Information obtained in 1939 from 626 livestock producers definitely indicates the need for giving attention to these items. For example, 85 farmers, or 14 percent of the 626 from whom information was obtained

\section{Table 17-Livestock Sold Through the Pittsburgh Branch of the Producers Cooperative Commission Association From Counties in West Virginia, 1942}

\begin{tabular}{|c|c|c|c|c|c|}
\hline County & Total & Cattle & Calves & $\begin{array}{l}\text { Sheep and } \\
\text { lambs }^{1}\end{array}$ & Hogs \\
\hline & bead & bead & bead & bead & bead \\
\hline Barbour & 1,217 & 181 & 655 & 309 & 72 \\
\hline Braxton & 3,032 & 33 & 38 & 2,950 & 11 \\
\hline Brooke & 18 & & & & 10 \\
\hline Doddridge & 4,158 & 578 & 223 & 3,357 & . \\
\hline Fayette & 390 & & 2 & 388 & . \\
\hline Grant & 3,309 & & 32 & 3,277 & . \\
\hline Greenbrier & 9,669 & 136 & 325 & $9,20 \mathrm{~s}$ & 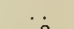 \\
\hline Harrison & 2,422 & 324 & 123 & 1,967 & 8 \\
\hline Jackson & & & & & . \\
\hline Jefferson & 529 & & 2 & 527 & . \\
\hline Lew is & 12,004 & 568 & 380 & 11,056 & $\cdots$ \\
\hline Marion & 98 & 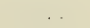 & & 98 & . \\
\hline Mercer & 3,343 & & 67 & 3,276 & \\
\hline $\begin{array}{l}\text { Monongalia } \\
\text { Ohio }\end{array}$ & $\begin{array}{l}124 \\
107\end{array}$ & 19 & 3 & 22 & $\begin{array}{r}80 \\
107\end{array}$ \\
\hline $\begin{array}{l}\text { Ohio } \\
\text { Pocahontas }\end{array}$ & $\begin{array}{r}10 \overline{7} \\
5,156\end{array}$ & & 155 & 5,001 & \\
\hline Preston & 184 & 34 & & 63 & 87 \\
\hline Randolph & 717 & & 4 & 713 & $\ldots$ \\
\hline Ritchie & 1,733 & 7 & 82 & 1,644 & . \\
\hline Roane & 7,668 & & 632 & 7,036 & $\cdots$ \\
\hline Summers & 2,052 & & 97 & 1,955 & \\
\hline Tyler & 82 & 30 & 2 & 42 & 8 \\
\hline Upshur & 26 & 22 & $\begin{array}{r}4 \\
80\end{array}$ & & 6 \\
\hline $\begin{array}{l}\text { Wetzel } \\
\text { Wood }\end{array}$ & 2,673 & & 338 & 2,329 & b \\
\hline Others & 45 & 10 & 14 & & 21 \\
\hline Total & 60,771 & 1,965 & 3,178 & 55,218 & 410 \\
\hline
\end{tabular}

${ }^{1}$ Includes business of the Eastern Order Buying Company. 
about marketing methods, reported that they sold through county and area cooperatives in 1939. Of this number, 72 considered themselves members. However, only 61 of the 626 farmers considered themselves regular patrons, although an additional 53 reported that they patronized livestock cooperatives from time to time. One hundred six farmers reported that they had used cooperative livestock associations for lambs, 21 for calves, and 6 for beef cattle. This substantiates the view that livestock cooperatives were primarily lamb associations, and that, if a noticeable increase in volume of business is to result, they will also need to give attention to other species of livestock.

Relatively few farmers were acquainted with the organization setup and operations of county and area livestock associations. Many considered livestock cooperatives as just another place to sell livestock or as an establishment run by the county agent or the Farm Bureau. To illustrate, of the 85 farmers who patronized cooperatives in 1939 , only 57 reported that they were acquainted with requirements for membership in county and area associations. Neither was the personnel of cooperatives well known. Managers of county associations were known to 117 out of the 626 farmers reporting, local directors to only 28, and the manager of the Pittsburgh branch to only 2. Likewise, only 34 farmers were acquainted with the frequency of holding county and area cooperative livestock meetings, and but 55 reported acquaintanceship with the nature of these meetings. These facts suggest that improvements in membership relations will be necessary before associations can expect an increase in patronage support. The establishment of news organs by state, and in some instances area associations, would be very helpful in acquainting patrons with the operations of livestock associations.

Consideration of the criticisms, strong points, and suggested improvements for cooperative livestock marketing associations, as offered by the farmers interviewed on marketing practices, should be helpful in suggesting directions in which educational and field work would be most effective. In all, 197 criticisms were offered by 133 farmers. These were reported as follows:

Type of criticism

Grading methcds

Management policies

High operating expenses

Poor and limited market outlets

Too limited service

Excess shrinkage

Unclassified

Number
of farmers
reporting
67
35
33
31
13
8
10

Without going into detailed consideration of these criticisms, certain items appear significant. The prevalence of criticisms relating to grading was largely due to the fact that the existing relationships of the grader to local associations, the Pittsburgh branch, and the national packer-buyer were confusing to many producers. Typical of the criticisms of high operating expenses was the statement, "it does not seem necessary to employ six to eight people to sell one deck of lambs." Criticisms of market outlets relate to the feasibility of the established non-competitive sales outlet through a national packer, disinclination to establish auction markets, and limited outlets for large numbers of feeder cattle and breeding stock.

One hundred ninety-nine farmers expressed one or more opinions as to strong points of cooperative associations. These included:

\section{Strong points}

Better returns

Grading

Improvement in livestock

Aids all cooperative effort

Better service

Unclassified

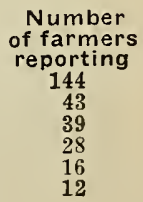


The emphasis on better returns as the most important contribution of cooperative livestock marketing associations suggests that cooperative success is closely related to business performance. That 43 farmers were impressed with grading indicates that progress is being made in this direction. Similarly, the number of farmers impressed with improvements in livestock and with aids to all cooperative efforts by farmers suggests that the educational activities of livestock associations, the animal husbandry work of the Agricultural Extension Division, and the activities of the State Department of Agriculture and other agencies, have all made contributions in establishing better livestock in the state.

Suggestions for improvement relate to operating practices, management, and grading methods. Suggested changes in operating practices included such items as: operation of livestock auctions, handling of all grades and classes of livestock, increasing the volume of business (particularly feeder cattle and calves), discontinuation of the policy of sellilig on a non-competitive basis, and the furnishing of suitable financial records. Suggestions for better management included the need for better selection of personnel to operate and direct cooperative associations, elimination of such practices as management buying and selling of livestock, substituting farmer participation for the county agent in cooperative livestock marketing, and establishing a carefully planned educational program designed to acquaint members and prospective members with accomplishments and operating methods of livestock associations serving West Virginia farmers. While much of the criticism of grading methods is not well founded, its prevalence suggests that livestock-marketing associations will need to give further attention to informing patrons of the merits of a sales policy based on premiums according to grade. To help acquaint patrons and prospective members with association performance and to act on the suggestion that more infcrmation concerning cooperative performance is needed, there is reason to believe that the state association would benefit by giving attention to establishing a news organ designed to go to all patrons of local associations. Furthermore, it is likely that the state organization, in cooperation with central-market cooperatives, will find it advantageous to take the lead in working out arrangements for increasing the volume of business, obtaining adequate trucking arrangements, and establishing approved accounting practices.

\section{THE WEST VIRGINIA LIVESTOCK MARKETING ASSOCIATION}

The West Virginia Livestock Marketing Association specifically has been financing local associations in acquiring needed facilities (scales, yards, and trucks); assisting some nımber associations in lamb-grading activities; promoting grading of lambs and calves; and conducting various kinds of field service and educational work.

Collection of fees or dues from member cooperatives has accounted for one-fifth to one-fourth of total receipts. For the past few years, refunds from the Pittsburgh Froducers for field work have equaled a like amount. This refund is accounted for by commissions paid the Pittsburgh Producers by the national packer-buyer for acting as its agent in the purchase of livestock.

The financial statements of the state association indicate that it has been financed more or less on a shoestring. Its limited receipts and assets, while permitting the association to assist in shaping cooperative live- 
stock marketing policies within the state, have not permitted the association to be as helpful in carrying on educational work and other services as seems desirable. To summarize, services that might be performed include: (1) supplying certified public accountants to perform auditing services for member associations, (2) undertaking of management training for local associations, (3) publication of a house organ designed to reach patrons of county and area associations, and (4) assisting county and area associations in critically reexamining organization and operating policies.

\section{TERMINAL-MARKET ASSOCIATIONS ${ }^{14}$}

It has been indicated that a close working relationship exists between the cooperative livestock marketing associations in West Virginia and the Producers Cooperative Commission Association (Pittsburgh branch). Since only limited information is available to producers and leaders in livestock marketing as it relates to the nature and extent of operation of these associations in West Virginia, it is believed that a brief description of central-market operations will be helpful.

While terminal-market associations first served local cooperatives by functioning only as terminal commission-sales agencies, activities have been expanded to include direct sales for numerous associations. This service was first undertaken in 1935 . While organized to assist in the direct sale of lambs, direct selling in some instances has been extended to cover the sale of veal calves, cattle, and hogs.

\section{THE PITTSBURGH BRANCH OF THE PRODUCERS COOPERA- TIVE COMMISSION ASSOCIATION ${ }^{15}$}

The Pittsburgh Market: ${ }^{16}$ Indication of trends in the number of various species of livestock received at the Pittsburgh market may be obtained by examination of Table 18 . From 1928 to 1941 there was a gradual decline in the number of head sold on the market $(1,054,713$ as compared with 331,808$)$. Contrary to this general trend, cattle numbers showed a slight increase. Calf numbers, however, declined one-third, sheep and lambs dropped somewhat over one-half, and hogs, four-fifths.

It is reported that the proportion of livestock received by truck increased from under 20 percent for cattle and calves in 1928 to about 85 percent by 1941 . Hogs, similarly, increased from less than one percent to about 75 percent during the same period. Much the same trends prevailed for sheep and lambs. In other words, there was a complete reversal in the position of rail and truck receipts between 1928 and 1941 . Marked improvement in the roads leading to Pittsburgh with a relative increase in the proportion of livestock received from nearby areas helps explain this trend.

Operating Policies of the Pittsburgh Branch: During early years of operation, about 80 percent of the business of the Pittsburgh branch was obtained from local shipping associations. They accounted for about

14Although no longer active, the Eastern Livestock Cooperative Marketing Association, Inc., which operated from 1932 through 1938, served a considerable number .)f West Virginia famers. Headquarters were located in Baltimore, and business activities covered eastern states-principally Virginia, Pennsylvania, West Virginia, Maryland, and North Carolina. During its seven years of operation the associatior did business in excess of $\$ 14,000,000$. The livestock handled included 113,000 cattle, 21,000 calves, 543,000 sheep and lambs, and 170,000 hogs.

It is reported that factors contributing to the discontinuance of the assor.iati $n$ included: (1) weali financial structure, (2) failure to obtain adequate membership 
Table 18-Number of Head of Livestock Sold at the Pittsburgh Market, 1928-1941

\begin{tabular}{|c|c|c|c|c|c|}
\hline \multirow[b]{2}{*}{ Year } & \multirow[b]{2}{*}{$\begin{array}{c}\text { Total ail species } \\
\text { and classes }\end{array}$} & \multicolumn{4}{|c|}{ Livestock species and class } \\
\hline & & Cattle & Calves & $\begin{array}{l}\text { Sheep and } \\
\text { lambs }\end{array}$ & Hogs \\
\hline & bead & bead & bead & bead & bead \\
\hline 1928 & $1,054,713$ & 56,054 & 74,672 & 252,182 & 671,805 \\
\hline 1929 & 989,250 & 44,942 & 66,195 & 276,219 & 601,894 \\
\hline 1930 & $1,133,226$ & 58,529 & 103,855 & 406,998 & 563,844 \\
\hline 1931 & 997,556 & 59,405 & 99,395 & 433,806 & 404,950 \\
\hline 1932 & 985,811 & 49,433 & 59,403 & 416,321 & 466,654 \\
\hline 1933 & 983,705 & 38,729 & 61,635 & 339,951 & 543,390 \\
\hline 1934 & 771,087 & 52,234 & 62,358 & 274,003 & 382,492 \\
\hline 1935 & 466,328 & 62,435 & 56,395 & 229,475 & 118,023 \\
\hline 1936 & 462,052 & 62,291 & 58,450 & 180,609 & 160,702 \\
\hline 1937 & 459,184 & 62,530 & 58,959 & 150,882 & 186,813 \\
\hline 1938 & 381,792 & 61,445 & 52,149 & 132,236 & 135,962 \\
\hline 1939 & 337,369 & 53,986 & 50,186 & 111,765 & 121,432 \\
\hline 1940 & 343,087 & 53,096 & 54,401 & 100,840 & 134,750 \\
\hline 1941 & 331,808 & 54,283 & 49,192 & 110,613 & 117,720 \\
\hline
\end{tabular}

73 percent of the association's business coming to the market. Because of changes brought about by such factors as trucking and livestock auctions, the shipping associations are out of business, and most of the livestock handled in 1942 came by truck as individual consignments or was sold direct to packers without passing through the Pittsburgh yards.

Certain aspects of the operating: policies adopted by the Pittsburgh branch are important. Market grades are not stable but fluctuate according to demand. To counterbalance this undesirable situation, a definite policy of producer and buyer service has been inaugurated whereby the
Producers attempts to assist its patrons. Furthermore, the association has devised special means of handling small consignments. These activities, combined with efforts to sell livestock on the basis of quality and grade, have enabled the association to set the pace on the Pittsburgh market. Randell reports that the prices obtained by the Pittsburgh branch for consignors compare favorably with general market quotations and in many instances are above such quotations. The practice was recently adopted of exchanging market information with the Cleveland, Indianapolis, and Buffalo agencies of the Producers Association.

support, and (3) management difficulties inherent in the rather loosely organized method of state representation. In addition, many of the buyers patronizing the association became insolvent and this, combined with the fact that the unsatisiactory policy had developed of selling to such buyers on a credit basis, contributed to the downfall of the association. During its period of existence, however, the association made significant contributions in the service of its member patrons. Additional markets were established, other's were stabilized, and trading ethics at established markets were improved. The various operating difficulties encountered by the association are illustrative of problems inherent in livestock marketing. They suggest that careful attention needs to be given to the solution of such problems before strong central-narket associations are possible.

${ }^{15}$ Data and information on the Pittsburgh market and the Pitsburgh branch of the Producers Cooperative Commission Association are based largely on a Preliminary Report on Survey of the Pittsburgh Livestock Market and the Producers Cooperative Commission Association, Pittsburgh, Pennsylvania, prepared by Mr. C. G. Randell of the Cooperative Research and Service Division, Farm Credit Administration, Washington, D. C. Appreciation also is due Mr. N. L. Claiborne, manager of the Pittsburgh branch, for offering helpful suggestions.

Producers interested in supplementary information concerning the operations of this association will find its annual report for 1942 very helpful.

${ }^{16}$ Agencies on the market included: The Pittsburgh Branch of the Producers Cooperative Commission Association; Shannon \& Farrell; Brinkman, Wood, and Beck; L. Dyer and Company; C. M. Stevens Commission Company; Union Livestock Company; W. W. Weaver and Company; W. A. Merritt; S. B. Hedges: Muhrbach, Donald, and Company; J. Need. Company; and I. Zigler \& Son. 
Importance of the Pittsburgh Branch in the Market: The volume burgh malket ${ }^{\text {hy }}$ y that branch of the Producers Cooperative Commission Association is presented in Table 19. Trends in the number of various species handled followed rather closely the trend in the total volume of business received at the yards. Also, the percentage of total sales (at the yards) made by the Producers in 1941 was approximately one-sixth of the cattle and calves, three-fifths of the sheep and lambs, and one-fifth of the hogs. There has been no appreciable change since 1934 in the proportion that cattle handled by the Pittsburgh branch were of the total cattle received there, although a new high of 18 percent of total volume was reached in 1940 The proportion of sheep and lambs handled has shown a more or less steady increase and in 1941 reached an all-time high of 60 percent. Some decline in the proportion of calves and hogs was ncticeable, particularly since the middle 1930's. An appreciable proportion of the cattle and hogs handled by the Pittsburgh Producer's moved direct since 1935 and consequently did not enter the terminal yards at Pittsburgh. This suggests that there is every reason to believe that the percentage of livestock handled cooperatively has continued to be a favorable proportion of the total livestock business in the region served.

Sales Methods: Not unlike other commission agencies, the Pittsburgh branch follows the general practice of selling cattle on an individual basis. In contrast with other commission agencies, how e ver, this branch was the only establishment handling any significant volume of livestock on a direct-to-packer basis. The general sales policy was to act strictly in a brokerage capacity for producers. In other words, livestock was not purchased on account. Some old-line commission firms operating on the market, in contrast, have developed the practice of purchasing livestock outright from time to time. Furthermore, in many instances these firms have established operating relations with truckers. Such re-

\section{Table 19-Volume of Livestock Handled by the Pittsburgh Branch of the Producers Cooperative Commission Association and the Per- centage That This Volume is of Total Market Receipts, 1928-1941}

\begin{tabular}{|c|c|c|c|c|c|c|c|c|}
\hline \multirow[b]{3}{*}{ Year } & \multicolumn{8}{|c|}{ Livestock species and class $^{1}$} \\
\hline & \multicolumn{2}{|r|}{ Cattle } & \multicolumn{2}{|c|}{ Calves } & \multicolumn{2}{|c|}{ Sheep and lambs } & \multicolumn{2}{|r|}{ Hogs } \\
\hline & $\underset{\text { ber }}{\text { Num - }}$ & $\begin{array}{l}\text { Percent- } \\
\text { age of mar- } \\
\text { ket receipts }\end{array}$ & $\begin{array}{c}\text { Num - } \\
\text { ber }\end{array}$ & $\mid \begin{array}{c}\text { Percent- } \\
\text { age of mar- } \\
\text { ket receipts }\end{array}$ & $\underset{\text { ber }}{\text { Num- }}$ & $\begin{array}{l}\text { Percent- } \\
\text { age of mar- } \\
\text { ket receipts }\end{array}$ & Num- & $\begin{array}{l}\text { Percent- } \\
\text { age of mar- } \\
\text { ket receipts }\end{array}$ \\
\hline & bead & percent & bead & percent & bead & percent & bead & percent \\
\hline $\begin{array}{l}1928 \\
1929\end{array}$ & $\begin{array}{l}5,966 \\
6,437\end{array}$ & $\begin{array}{l}11 \\
14\end{array}$ & 19,694 & $\begin{array}{l}26 \\
31\end{array}$ & 79,715 & 32 & 206,55 & 31 \\
\hline 1930 & 8,117 & $\begin{array}{l}14 \\
14\end{array}$ & $\begin{array}{l}20,402 \\
23,008\end{array}$ & $\begin{array}{l}31 \\
22\end{array}$ & $\begin{array}{l}100,756 \\
140,857\end{array}$ & $\begin{array}{l}37 \\
35\end{array}$ & 210,760 & 35 \\
\hline 1931 & 5,959 & 10 & 20,897 & 21 & 130,011 & $\begin{array}{l}35 \\
30\end{array}$ & $\begin{array}{l}164,586 \\
140,849\end{array}$ & $\begin{array}{l}29 \\
35\end{array}$ \\
\hline 1932 & 4,766 & 11 & 15,813 & 27 & 142,356 & 34 & 143,606 & 31 \\
\hline 1933 & 4,135 & 11 & $13,55 \mathrm{~S}$ & 22 & 113,351 & $\begin{array}{l}04 \\
33\end{array}$ & 168,482 & $\begin{array}{l}31 \\
31\end{array}$ \\
\hline 1934 & 8,311 & 16 & 13,702 & 22 & 110,408 & 40 & 115,664 & 30 \\
\hline 1935 & 8,836 & 14 & 9,859 & 18 & 106,593 & 42 & 45,055 & 38 \\
\hline 1936 & 8,686 & 14 & 7,783 & 13 & 107,783 & 50 & $\begin{array}{l}45,000 \\
35,664\end{array}$ & $\begin{array}{l}00 \\
22\end{array}$ \\
\hline 1937 & 9,768 & $\begin{array}{l}16 \\
16\end{array}$ & 8,322 & 14 & 86,730 & 44 & 39,696 & 21 \\
\hline 1938 & 10,145 & 17 & 6,993 & 13 & 87,458 & 52 & 28,522 & 21 \\
\hline 1939 & 8,972 & 17 & 7,498 & 15 & 79,069 & 52 & 25,720 & 21 \\
\hline 1940 & 9,589 & 18 & 8,480 & 16 & 83,364 & 55 & 23,667 & 18 \\
\hline 1941 & 9,277 & 17 & 8,406 & 17 & 94,997 & 60 & 22,290 & $\begin{array}{l}10 \\
19\end{array}$ \\
\hline
\end{tabular}

1Does not include livestock sold direct to packers, except in the case of sheep and lambs, in which case total market receipts were calculated by adding the lambs tive Commission Association. 
lations often include the financing of trucks and the furnishing of working capital by commission agencies to buy livestock in the country. In return they usually receive all livestock that such truckers buy. One firm was reported to be financing as many as 20 truckers.

Educational Work: In, all, the Pittsburgh Producers devoted 166 days to educational and field work. Of this amount, $31 \frac{1 / 2}{2}$ days were spent in West Virginia. This compares with 64 days in Ohio, 59 days in Pennsylvania, $10 \frac{1}{2}$ days in Indiana, and 1 day in Michigan. The number of counties in West Virginia according to days of educational and field work was reported as follows:

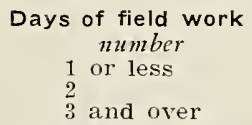

Counties
number
7
4
4

Randall reports that field service has been established primarily along seven lines. These are:

1. Developing working arrangements with truckers and dealer's in the market territory. In 1939 the association had a record of 139 truckers in 95 towns, including 31 truckers in 20 West Virginia towns.

2. Appraising weights and value of livestock. The association reported that this type of service represented 25 percent of the calls coming to it from producers.

3. Setting up meetings with the assistance of general farm organizations, marketing associations, and colleges of agriculture. Meetings are arranged which, in addition to entertainment, consist of general discussion of the marketing services of the association, outlook information for various species of livestock, and consideration of possibilities of developing: trucking routes or other current problems.

4. Taking orders for stocker and feeder cattle.

5. Participation in cattle- and lamb-feeding tours and grad- ing demonstrations.

6. Initiating market tours.

7. Inspecting livestock-production loans.

Items 1, 2, 4, and 7 are definitely a part of the association's business operations. It primarily is through items 3, 5, and 6 that patrons have the opportunity of obtaining information that will give them a better appreciation of the scope of operations of the association.

In addition, the Pittsburgh branch uses such means of publicity as newspapers, radio, and personal contact. News material was sent out to weekly papers and farm magazines in the trade territory. The radio was used primarily for market broadcasts. Market cards were sent out weekly to about 700 shippers and truckers. Likewise, the Producers News, the house organ of the Producers Cooperative Commission Association, showing the results of branch operations, has wide distribution.

Direct Marketing: In order to combat the inroads of livestock auctions on its volume of business, the Producer's gave attention to direct marketing as early as 1935. At that time the Eastern Order Buying Company, with headquarters at Columbus, Ohio, and operating branches at Pittsburgh and other points, was established for the purpose of handling direct sales to packers. Some indication of the volume of business conducted by the Pittsburgh branch of the Eastern Order Buying Company for the period 1935-1942 is indicated by the following data:

\section{Livestock species and class}

\begin{tabular}{|c|c|c|c|c|}
\hline Year & $\begin{array}{c}\text { Cattle } \\
\text { bead }\end{array}$ & $\begin{array}{c}\text { Calves } \\
\text { bead }\end{array}$ & $\begin{array}{c}\text { Sheep and } \\
\text { lambs } \\
\text { bead }\end{array}$ & $\begin{array}{l}\text { Hogs } \\
\text { bead }\end{array}$ \\
\hline 1935 & 3,266 & 4,209 & 126,150 & 31,487 \\
\hline 193 & 2.954 & 3,227 & 118,535 & 25,487 \\
\hline 1937 & 3,221 & 3,573 & 81,180 & 25,086 \\
\hline 1938 & 1,848 & 2,921 & 61,885 & 23,820 \\
\hline 1939 & 1,598 & 2,909 & 66,522 & 70,324 \\
\hline 1940 & 2,391 & 4,076 & 70.881 & 133,666 \\
\hline 1941 & 2,168 & 4,040 & 78,982 & 111,183 \\
\hline 1942 & 6,788 & 3,526 & 91,159 & 152,024 \\
\hline
\end{tabular}


These data show that, except for hogs and cattle in 1942, the volume of order-buying business of the Pittsburgh branch has declined slightly since it began in $1935 .^{17} \mathrm{Di}-$ rect sales in 1942 were $64,53,113$, and 898 percent, respectively, of central-market sales of cattle, calves, sheep and lambs, and hogs by the Pittsburgh branch on the Pittsburgh market, for the same year. There was some change in the proportion of direct to total sales on this market for calves and sheep and lambs. Direct sales of cattle were twice as high in 1942 as in 1935, while direct sales of hogs were five times as high in 1942 as in 1935. It also may be noticed that sheep and lambs and hogs constitute the more important livestock sold direct.

No hogs in West Virginia were sold direct to the Eastern Order Buying Company, but approximately twothirds of the lambs handled by this company, together with a few calves, came from this state.

The distribution of order-buying receipts in 1939, by species and class according to state of origin, was as follows :

\begin{tabular}{|c|c|c|c|c|}
\hline \multirow{3}{*}{$\begin{array}{l}\text { Pennsylvania } \\
\text { West Virginia }\end{array}$} & \multicolumn{4}{|c|}{$\begin{array}{c}\text { Livestock species and class } \\
\text { Cattle Calves Sheep Hogs } \\
\text { and lambs }\end{array}$} \\
\hline & $\begin{array}{l}\text { bead } \\
711\end{array}$ & $\begin{array}{r}\text { bead } \\
1,898\end{array}$ & bead & $\begin{array}{r}\text { bead } \\
17,244\end{array}$ \\
\hline & 119 & 946 & 41,847 & \\
\hline & & 43 & $\begin{array}{r}644 \\
3,144\end{array}$ & \\
\hline $\begin{array}{l}\text { ana } \\
\text { er }\end{array}$ & $\begin{array}{r}27 \\
689\end{array}$ & .. & 202 & \\
\hline
\end{tabular}

The Pittsburgh branch has a definite tie-up with the West Virginia Livestock Marketing Association in its direct-marketing arrangements. The present sales policies are based on year-to-year arrangements with Swift \& Company and other large packers for the sale of lambs and calves. When first inaugurated, weights were shrunk 4 percent at loading-points. Due to dissatisfac- ticn, this practice was changed, and since 1938, no shrinkage allowance has been granted, but shrinkage has been taken into account in establishing prices.

Stocker and Feeder Cattle: In 1939 , the Pittsburgh branch inaugurated the practice of buying stocker and feeder cattle for its patrons. During that year, 1,145 head were handled. The majority of these came from Texas and other western states, although a limited number were purchased at the Pittsburgh yards. The association reports that all but 105 head were sold to Pennsylvania farmers. In addition, feeder lambs also have been handled. These policies are in accordance with the sound principle that one of the best ways to obtain livestock is to influence favorably the production of livestock in the market area.

Credit Association: In connection with its stocker and fzeder activities, the Producer's Cooperative Commission Association alsc has established a Producers Livestock Credit Association, a suisidiary, for the purpose of financing livestock farmers on terms best suited to their needs. The association reported that up to December 31,1942 , producers' loans totaling over $\$ 5,000,000$ had been granted. Interest rates were $4 \frac{1}{2}$ percent, payable only for the time the money was used. Loans have been made for a period of one year or longer. Members have no capital-stock investment, and they have no financial responsibility beyond the extent of their loan.

$M$ e $m b$ er-relationship Problems: Important problems of operation for the Pittsburgh branch of the Producers Association relate to the activities of county and area livestock marketing cooperatives such as operate in West Virginia. Some of

${ }_{17} \mathrm{No}$ definite information is available as to the extent of direct sales of other commission firms on the Pittsburgh market. Reports, however, indicate that this volume is negligible. 
the more important problems relate to development of more permanent county units, establishment of trucking service, relationships with general farm organizations and colleges of agriculture, and the working out of means to tighten up local inspection and sanitary regulations.

Judged by standards of performance in many other sections of the country, the local associations from which the Pittsburgh Producers must recruit its support in West Virginia frequently are handicapped by such considerations as the limited amount of-farmer leadership available and the lack of business volume. This suggests that the association may want to assist many local coop- eratives in bringing about improvements in operating practices. To accomplish this, further steps may need to be taken to acquaint member associations and member producers with the activities of the Producers Association. Other possibilities include consideration of establishing trucking routes from certain producing areas, examination of operating practices to the end of increasing business, assisting with accounting problems, and rendering of auditing services. The Producers Commission Association also may want to consider the advisability of encouraging the tightening up on local inspection and sanitary regulations.

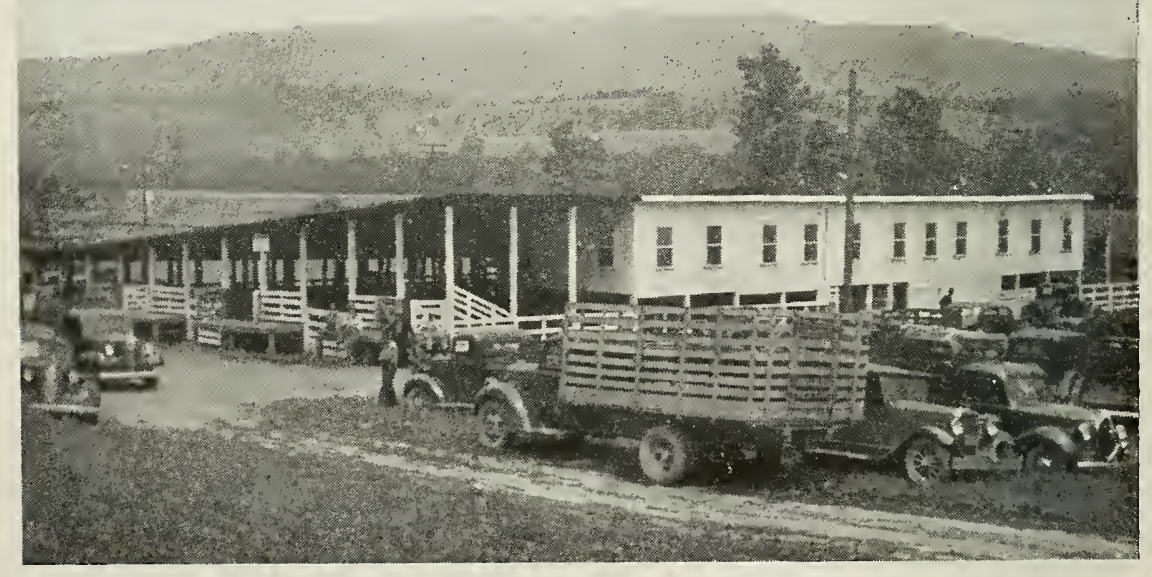

Fig. 18-A Representative Auction Barn in West Virginia

\section{LIVESTOCK AUCTIONS IN WEST VIRGINIA}

\section{DEVELCPMENT}

While it is impossible to measure definitely the influence of each of many factors that have contributed to the development of livestock auctions, it is certain that improvements in roads, with consequent growth in trucking, has been important. Coupled with these developments have been such factors as inadequate and declining rail service, inefficient operation of some terminal markets, and failure or inability of other terminal agencies to render the services desired. In any event, auctions con- 
Table 20-Time of Organization and Status in 1940 as Reported for 25 Livestock Auctions in West Virginia

\begin{tabular}{|c|c|c|c|}
\hline \multirow{2}{*}{$\begin{array}{c}\text { Year } \\
\text { chartered }\end{array}$} & \multirow{2}{*}{$\begin{array}{l}\text { Auctions } \\
\text { organized }\end{array}$} & \multicolumn{2}{|c|}{ Status in 1940} \\
\hline & & Active ${ }^{1}$ & I Inactive \\
\hline & number & $n u m b e r$ & number \\
\hline 1932 & 4 & 4 & \\
\hline $\begin{array}{l}1933 \\
1934\end{array}$ & 5 & 4 & 1 \\
\hline $\begin{array}{l}1904 \\
1935\end{array}$ & 2 & $\begin{array}{l} \pm \\
2\end{array}$ & \\
\hline 1936 & 5 & 5 & \\
\hline 1937 & 5 & 4 & 1 \\
\hline 1938 & 2 & 1 & 1 \\
\hline 1939 & 1 & & 1 \\
\hline 1940 & 1 & 1 & . \\
\hline Total & 25 & 21 & 4 \\
\hline
\end{tabular}

${ }^{1}$ Five of the auctions that were active in 1940 at one time or another have dissolved, remained inactive for a time, and eventually have reorganized since the granting of the original charter.

stitute the newest and most important development in livestock marketing in the state.

The first auction to be organized was the Spencer Livestock Exchange Company, chartered February 11, 1932. Since that time 25 auctions have been organized (Table 20). Of this number, 21 were still in operation in 1940, even though 5 of those operating had been reorganized -some as often as two or three times. Data for the nine-year period 1932-1940 show that 9 auctions were organized during the first three years, 12 during the next three years, and 4 during the next three years. Seemingly the period of rapid expansion in auction numbers is over.

As reported in 1940 , five auctions were located in the eastern livestock area of West Virginia, seven in the central livestock area, and nine in the dairy and general-farm and selfsufficing area (Figs. 1 and 2).

\section{THE NATURE AND EXTENT OF BUSINESS}

Non-livestock Business: The business activity of livestock auctions is very largely restricted to the handling of livestock. Limited amounts of other products were sold, however, by all but 2 auctions. In 1939, this amounted to about $\$ 90,000$ or slightly over one percent of the total business of the 19 auctions reporting.

While a few auctions follow the practice of selling "anything the farmer has to offer," and some have even gone outside of the strictly agricultural field, the general practice has been not to encourage this type of business. Most auction operators are of the opinion that auctions should take steps to make their patrons "livestock conscious" rather than divert attention through various sideline activities.

Operators permitting or encouraging non-livestock business reported that such items as implements and equipment, harnesses, household goods, and farm produce (in season) constituted the principal products handled. Some auctions at times sold such items as poultry, eggs, chicks, fenceposts, and clothing. A few auctions permitted the sale of patent medicine. Many farmers have raised justifiable objection, however, to spending 20 to 30 minutes in the sales pavilion while some vendor puts on his show. Still others object to what they consider the dissocial aspects of such a performance.

While there is no reason why commodities other than livestock cannot be sold at auction, there is reason to believe that as a rule it is not desirable to mix the sale of livestock with other items. If non-livestock items are to be sold, it would be advisable to establish separate and suitable facilities and to hold such auctions on other days.

Livestock Business: The number of head of various species and classes of livestock handled by auction markets in 1939 and their estimated value are given in Table 21. It may be noted that total sales value for 
the 428,690 head handled approximated seven and one-half million dollars.

Eight auctions, representing approximately 60 percent of the annual livestock auction business, furnished information as to the monthly distribution of sales (Table 22). The three high months (August, September, and October) accounted for approximately one-half of sales, while the three low months (January, February, and March or December) accounted for only one-tenth of total sales. This explains why auction personnel and facilities were not used at anything approaching capacity much of the year.

Scope of business activities varied widely. Some auctions merely stated that they were organized to "buy, sell, and trade in livestock." Others, in contrast, reported their stated purpose to include:

"To buy, sell, exchange, market, handle, import, export, store, deliver, and generally trade in as principal agent, factor, or commission man or ctherwise, at wholesale, retail, public auction or private sale, cows, calves, cattle, sheep, hogs, horses, chickens, turkeys, ducks, and other livestock and fowl of every kind and description, wool, grain, feed, fertilizer, lime, farm implements, machinery, apparatus, tools, agricultural products, and other items of personal property of every kind, character, and description ...."
Other specific provisions in the charters of some auctions included: (1) dealing "exclusively in livestock"; (2) "processing meat and meat products"; (3) "raising, breeding, fattening, and marketing livestock"; and (4) "acting as agent for livestock and other property belonging to itself and others." The latter provision is significant in that it presents definite evidence that some auctions have deliberately set out to obtain permission to operate as both commission men and dealers. More will be said about this relationship.

\section{ORGANIZATION}

Capitalizaticn: Of the 21 livestock auctions operating in the state in 1940,20 were operated as private corporations and one was individually owned and operated. No auctions were operated on a cooperative basis in West Virginia. ${ }^{18}$

The general practice among livestock auctions has been to sell stock with shares at a par value of $\$ 50$ or $\$ 100$ each. Two of the auctions reported both common and preferred stock. The amount of capital stock as reported for 19 livestock auctions totaled $\$ 139,375$. In 1940 this represented an average of $\$ 7,335$ per auction, ranging from $\$ 1,000$ to $\$ 18,075$. The amount of capital stock outstanding is approximately three times the amount originally

\section{Table 21 -Estimated Number of Head, Value, and Percentage Distribution of Value for Livestock Sold Through Auctions, as Reported for 20 Markets in West Virginia, 1939}

\begin{tabular}{c|ccc}
\hline $\begin{array}{c}\text { Livestock species } \\
\text { and class }\end{array}$ & Number & Value & $\begin{array}{c}\text { Percentage } \\
\text { of total }\end{array}$ \\
\cline { 3 - 3 } & & Total & percent \\
Cattle & bead & $4,342,956$ & 58.0 \\
Calves & 95,012 & $1,240,546$ & 16.6 \\
Sheep and lambs & 87,832 & 507,667 & 12.1 \\
Swine & 161,953 & 660,499 & 8.8 \\
Holses & 78,392 & 330,218 & 4.5 \\
Total & 5,501 & $7,481,856$ & 100.0
\end{tabular}

'Sales for the auction not reporting did not account for more than an additional 5 percent of total sales. 
subscribed and about three-fifths the total authorized. Nine of the auctions were capitalized to the extent authorized. The amount of capital stock outstanding for 19 auctions was distributed as follows: $\$ 5,000$ or less, 10 auctions; $\$ 5,001-\$ 10,000,3$ auctions; $\$ 10,001-\$ 15,000,5$ auctions; and $\$ 15,001$ and over, 1 auction.

Stockholders: Those auctions organized as corporations as a rule have followed the practice of operating as semi-closed establishments, limiting the ownership of stock to promoters and to certain influential cattle producers and dealers. A few auctions, however, have followed the practice of attempting to obtain as many producer-owners as possible. This was done with the idea of attempting to assure a supply of livestock and to enhance local interest in the auction operation. The distribu. tion of the number of stockholders per auction was reported for 19 auctions as follows: 5 or less, six auctions; $6-10$, six auctions; $11-50$, six auctions; and 51 and over, one auction.

Operators of livestock auctions reported that, to an appreciable degree, stockholders were interested in more than one auction. In fact 15 out of 20 auctions reported that 33 stockholders have such interest. Eight auctions reported that at least 17 stockholders were out-of-state individuals.

While it is difficult to evaluate accurately the consequences of these ownership relations, there is some reason to believe that at times they are detrimental both to the best longtime interests of livestock auctions and to the farmers who patronize them. In some instances auctions have developed the scheme of using some prominent individuals connected with other auctions or in other kinds of business primarily for windowdressing purposes. As such the individuals take little or no active part in business operations. In some instances the same individual has a

Table 22-Seasonal Distribution of Annual Livestock Sales as Reported for Eight Auction Markets in West Virginia, 1939

\begin{tabular}{|c|c|c|c|c|c|c|}
\hline \multirow[b]{2}{*}{ Months } & \multicolumn{5}{|c|}{ Species and class of livestock } & \multirow{2}{*}{$\begin{array}{c}\text { Total } \\
\text { sales } \\
\text { (dollars) }\end{array}$} \\
\hline & Cattle & Calves & $\begin{array}{c}\text { Sheep and } \\
\text { lambs }\end{array}$ & Swine & Horses & \\
\hline & percent & percent & percent & percent & percent & percent \\
\hline January & 3.2 & 4.1 & 0.8 & 9.6 & 4.7 & 3.8 \\
\hline February & 2.8 & 3.5 & 0.5 & 9.9 & 9.5 & 3.5 \\
\hline March & 3.4 & 4.3 & 0.6 & 10.5 & 16.3 & 4.1 \\
\hline April & 4.2 & 6.4 & 1.0 & 6.8 & 17.9 & 4.6 \\
\hline May & 5.1 & 11.1 & 2.6 & 8.1 & 14.2 & 5.2 \\
\hline June & 5.9 & 14.2 & 6.4 & 6.4 & 7.8 & 6.3 \\
\hline July & 7.7 & 12.5 & 13.0 & 5.5 & 6.2 & 9.2 \\
\hline August & 11.3 & 11.2 & 28.6 & 5.5 & 5.3 & 11.8 \\
\hline September & 21.7 & 12.8 & 26.4 & 7.7 & 2.6 & 19.7 \\
\hline October & 19.9 & 9.0 & 13.1 & 10.1 & 6.1 & 18.7 \\
\hline November & 10.1 & 6.7 & 5.8 & 11.5 & 5.5 & 9.0 \\
\hline December & 4.7 & 4.2 & 1.2 & 8.4 & 3.9 & 4.1 \\
\hline Total & 100.0 & 100.0 & 100.0 & 100.0 & 100.0 & 100.0 \\
\hline
\end{tabular}

18In the summer of 1941 the West Central Producers Cooperative Assuciation, representing farmers in the northwestern part of the state, attempted tu operate a livestock auction on a cooperative basis at Ellenboro, W. Va., the location of an established auction. They were not granted a permit to operate and they were enjoined from operation by the State Department of Agriculture. In appealing this action, the State Supreme Court of Appeals held (two judges dissenting) that the ruling of the Commissioner of Agriculture should not be disturbed in the matter of adninistrative findings. The court went further and held that the Cooperative Association Statute of West Virginia was not intended to authorize the operation of public markets. Without considering the merits or demerits of the ruling in the particular case at point, it is unfortunate that the court went further and held that cooperative law did not intend the operation of public markets. Such opinion concerning the functions of cooperative associations prevents them from making adjustments necessary to keep abreast of the times. Even though the auction method of operation is universally 
considerable financial interest in two or more auctions, and these auctions reported some little inter-auction business. It is often difficult to convince consignors that such interauction transactions are on the "up and up." To the extent that market costs are increased because livestock is moved from auction to auction, the farmer usually pays these costs because it results in lower prices for his livestock.

At a few auctions there was definite evidence that some in-state and some out-of-state stockholders represented dealer and slaughter interests. It is difficult to see how such interests can serve farmers with singleness of purpose as long as there is a possibility that they represent individuals or interests seeking to obtain livestock at the lowest prices possible. They cannot always be expected to exert all means to see that farmers get market prices, when to do so would have the effect of increasing the cost of livestock they need for their business operations.

Promoter's from Ohio and Kentucky were instrumental in organizing the first auctions in West Virginia in territory adjacent to the Ohio River. Similarly, Virginia and Southern West Virginia interests were instrumental in establishing auctions in the eastern part of the state. Once an auction was established, these promoters usually followed the practice of either selling out and moving on or taking in local dealers. Consequently, ownership in livestock auctions has become appreciably more local and more stabilized than during the early years of operation.

There also was evidence that a $f \in w$ auctions have developed a distinct separation between ownership and management. It is not at all uncommon for some of the auctions to lease facilities to a group of adventurous individuals who are willing to take a "fling" at the auction business. This has meant frequent changes in operation personnel and has not, as a rule, resulted in the establishment of permanent and desirable relations between consignors and management.

Size of Trading Territory: The trading territory of livestock auctions in West Virginia is limited. The average of maximum distances from which livestock was received was 46 miles for all auctions. Three auctions reported all consignments from a distance of 25 miles or less, 12 reported all consignments within a distance of 50 miles, and 5 reported some consignments over 50 miles. Three of this number reported that they received some livestock from a radius of over 100 miles.

The percentage of total value of consignments according to distance from auctions, as estimated by officers of 19 auctions, was reported as follows: 25 miles or less, 62 percent; $26-50$ miles, 25 percent; and 51 miles and over, 13 percent. Five auctions in the dairy and general farming regions reported 51 percent of all consignments from within a 25 -mile radius and 30 and 19 percent, respectively, in the $26-50$ and the 51-miles-and-over distances. This variation was due in part to the fact that they were located in territories having a higher than average proportion of cull cattle and veal calves. Since auctions have proved to be particularly good markets for such livestock, there was a tendency to bring it in from greater distances than was the case in other farming regions.

Further consideration of the size

recognized as coming within the province of cooperative law, in West Virginia it seems impossible for farmers, as a consequence of this ruling, to organize a cooperative livestock auction or, for that matter, any cooperative auction. 
of trading territory of auction markets suggests that considerable duplication of services exists. Thirteen auctions were located within 20 miles of other auctions when the location of those in nearby states is taken into consideration. Only three auctions were 50 or more miles distant from other auctions.

There is reason to believe that if some auctions now operating were consolidated with others, considerable improvement in the auction system of selling would be possible. For example, eight auctions, so situated that they offer direct competition to other auctions, together did less than $\$ 1,000,000$ of business in 1939. Such restricted volume means limited buying competition for farmers' livestock because of inability to interest many of the larger buyers. Furthermore, if the limited business of the smaller auctions were proportioned among other auctions, bargaining power would be increased as the remaining ones would attract a greater number of buyers. The State Department of Agriculture, through the provision requiring it to pass on applications for permits to operate auctions, is in position to exert considerable influence in restricting the number of auctions operating. By prohibiting the organization of new auctions and the reorganization of small and competing auctions, competition could be restricted and consolidations effected. In this connection it should be noted that some of the larger packer-buyers seem interested in maintaining competition between auctions, and for that mat$t \in \mathrm{r}$ between auctions and other market agencies, in order to divide farmer bargaining power.

Operating Facilities: Twenty-one auctions reported information as to operating facilities. All but three were conducted in buildings owned by the management. Those operat- ing with rented facilities reported rental fees at between $\$ 50$ and $\$ 60$ per month. Little difference existed in the investment per auction when classified according to size of business operation. The smaller auctions have slightly larger investments in buildings than the larger ones. For example, investments in buildings averaged $\$ 4,395$ per auction for seven of those reporting an annual business of over $\$ 250,000$, and $\$ 4$,929 per auction for nine of those with an annual business of less than $\$ 250,000$. This means considerably more overhead and expense per dollar of sales for the small auctions -and adds to the cost of marketing. The average investment in buildings as reported for all auctions was $\$ 4,694$. The distribution of the number of auctions according to the present value of investment in buildings was reported at $\$ 3,000$ or less for three auctions, $\$ 3,001-\$ 6,000$ for nine auctions, and $\$ 6,001$ and over for four auctions.

Nine auctions reported the leasing of land, usually from railroads, and nine reported ownership of land. The value of the auction land and equipment ranged from $\$ 500$ to $\$ 9,000$ (including switches) and averaged $\$ 2,956$ per establishment. Rent paid for land ranged from $\$ 25$ to $\$ 200$ per year and averaged $\$ 88$ per auction.

In addition to the regular sales pavilions, a few auctions had additional sheds or pens for large runs of liv€stock, especially lambs and veal calves. Two auctions reported using special buildings in which to hold horse sales. In addition, practically all auctions had arrangements for the operation of a restaurant. While a few auctions actively operated restaurants, the usual practice was to lease the restaurant on an annual basis to individuals or to some women's organization. One auction 
has Established an attractive restaurant located separately from the sales building.

Careful consideration of plant arrangement would do much to facilitate the handling of livestock. ${ }^{19}$ Particular consideration should be given to such matters as: (1) large and adequate parking facilities for both consignors and buyers, (2) sufficient facilities for efficient handling of livestock (both unloading and loading), (3) handy arrangements for weighing, and (4) a convenient sales pavilion with suitable arrangements for bringing livestock both into and out of the sales ring.

Experience has demonstrated that more effective operation is obtained when pavilion arrangements are such that all potential buyers can be seen from the auctioneer's booth. This restricts buyers to the side opposite the auctioneer and to the ends of the pavilion. Many auctions would improve their arrangements if special efforts were made to clear the sales ring of loafers and all individuals other than auction employees. To allow such individuals in the ring not only obstructs the view of buyers but at times is a hazard. Adequately fenced and arranged sales pavilions in addition to a determined policy on the part of management can do much to remedy these abuses.

Some auctions have no boarded division setting the pavilion apart from livestock pens. Confusion and noise acid to the difficulty of conducting a satisfactory sale under such conditions. These difficulties are likely to be more common when auctions are held in establishments not spe- cifically designed for auction purposes.

\section{OPERATING PRACTICES}

\section{Methods of Receiving and Dispens-} ing Livestock: ${ }^{20}$ Auctions usually open at between $6: 00$ and $8: 30$ a.m. on sales days to receive livestock. A few auctions follow the practice of receiving livestock on the day before the sale. When received, livestock is sorted or graded, and placed in the desired pens.

Eight auctions report that they begin sales at $1: 00$ p.m., 10 at $1: 30$, and 3 at $2: 00$. In actual practice most sales begin somewhat later than scheduled because of delays in getting all the livestock in and because of the difficulty of getting buyers together before they have had an opportunity to look over the availatle livestock.

As a rule, auctions have so staggered their sales days that they permit those dealers that so desire to travel a "circuit" of four to five auctions a week. Occasionally, however, nearby auctions engage in direct competition, holding their sales on the same day.

For practical purposes all livestock received at auctions came by truck. Only four auctions reported rail receipts and eight any significant number of livestock driven in. In no instance did truck receipts account for less than 80 percent of the total and the average was 97 percent. Livestock driven in and arriving by rail was estimated to account for only 2 and 1 percent, respectively, of total receipts.

As would be expected, somewhat more livestock left auctions by rail than was received by rail. All but three auctions reported that some

\footnotetext{
${ }^{19} \mathrm{~A}$ detailed discussion of plant arrangement is presented in Livestock Auction Sales in the United States, Cooperative Research and Service Division, Farm Credit Administration, C. G. Randell and L. B. Mann, Bulletin No. 35, 1939, pp. 29-35.

${ }^{20}$ For an illustration of sone of the operating forms used by auction markets see Randell and Mann, op. cit., pp. 111-113.
} 
stock laft by rail. The average percentage of stock (as measured by dollar sales) so leaving was 24 percent as compared with 76 percent by truck. Eight auctions reported that 25 percent or more of the total value left by rail and 3 reported this proportion at 50 percent and over. The proportion of truck-andrail shipments varied some with size of auction, as may be seen by estimates for 19 auctions for 1939 , which were as follows:

\begin{tabular}{|c|c|c|c|}
\hline $\begin{array}{l}\text { Size of } \\
\text { auction }\end{array}$ & $\begin{array}{l}\text { Auc- } \\
\text { tions }\end{array}$ & \multicolumn{2}{|c|}{$\begin{array}{c}\text { Percentage } \\
\text { of total } \\
\text { value moved } \\
\text { from auctions by: }\end{array}$} \\
\hline dollars & number & truck & rail \\
\hline 5,000 or less & 2 & 97 & 3 \\
\hline $5,001-250,000$ & $\&$ & 87 & 13 \\
\hline $50,001-500,000$ & 4 & 58 & 42 \\
\hline $00,001-750,000$ & 2 & 85 & 15 \\
\hline 50,001 ard over & 3 & 53 & $4 \vec{\imath}$ \\
\hline
\end{tabular}

Weighing Practices of Auction Markets: Eighteen auction markets reported that livestock was "weighed in" (at time of arrival), one that livestock was "weighed out" (after time of sale), and one, depending on species and class, reported weighing livestock both in and out. The practice of weighing livestock in has been subjected to considerable abuse at some auction markets. It has been mentioned that unethical dealers bring livestock to within a short distance of the market, give them excessive amounts of feed and water, and then rush them over the scales.

The West Virginia auction law requires that weighmasters be licensed and that only licensed weighers can weigh livestock at auction markets. Some of the larger auctions employed as many as four weighers, while smaller establishments had only one or two such employees.

It was previously indicated that the three largest auctions in the state were subject to the weighing provisions of the Packer and Stockyards Act. In addition, these as well as other auctions are subject to weigh-

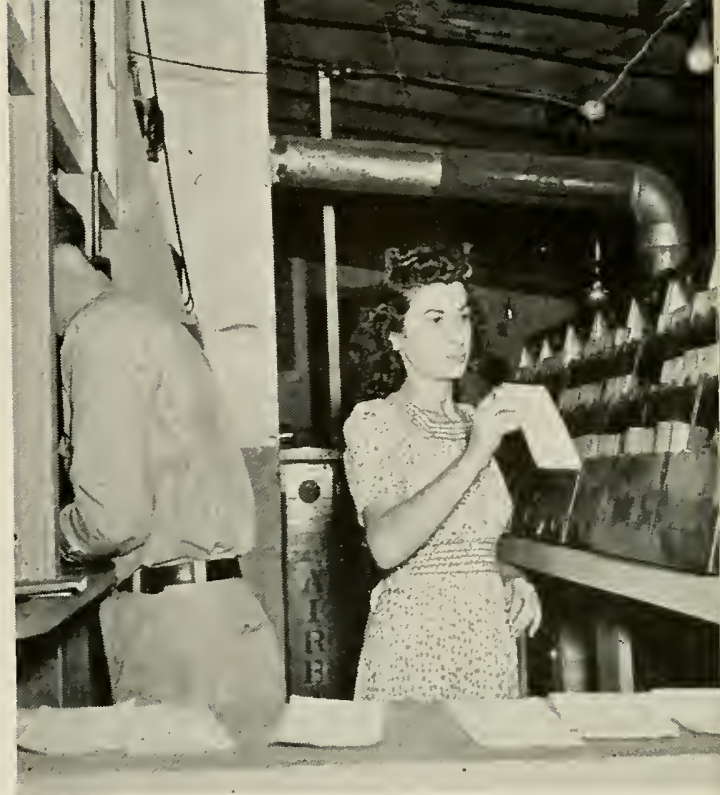

Fig 19-A Typical Operation in Receiving Livestock at Auction Markets

LIVESTOCK IS SORTED, TAGGED FOR IDENTIFI CATION AND WEIGHED. RECORDS AS TO CONSIGNORS, WEIGHT, CLASS, AND GRADE ARE FILED FOR SALES PUREOSES

ing regulations established by the state. They report that scales are checked from one to three times a year. Indications are, however, that the state is lacking in both the personnel and facilities necessary to test scales accurately at livestock auctions.

Four of the larger auctions in the state had two scales; all others had one. Most managers reported that the use of small scales for weighing single animals or small consignments in addition to a larger scale for large-lot consignments would do much to facilitate the handling of livestock.

Fifteen operators reported that their scales break on five pounds; three, on two pounds. Although the state law requires that recording scales with automatic ticket-punching be used, only 15 out of 19 auctions 
used such scales. One of the auctions having recording attachments did not use it unless consignors so requested. Auction operators would stand to benefit if they made a special point of: (1) checking the accuracy of scales, (2) using scales with registering beam and recording-ticket attachments, and (3) taking such other additional steps in weighing livestock as are necessary to improve consignor confidence.

Grading: Considerable variation exists as to the nature and extent of grading activities carried on at livestock auctions. In 1941,12 auction representatives reported utilizing the services of state lamb graders, and 10 used state graders for calves. Farmers have the privilege, however, of selling their lambs and calves individually or in such sized lots as they see fit. The number of farmers following this practice is decreasing. Six auctions reported that they followed the practice of "sorting" livestock (particularly lambs, calves, and hogs) according to size and weight. These auctions employed their own men to grade in this manner. It was done as closely as possible in accordance with the desires of various groups of buyers.

Auctions utilizing the services of state graders reporied that an average of 87 percent of the lambs and 78 percent of the calves were graded by this agency. In all instances those auctions grading lambs reported that 75 percent or more of the lambs and 60 percent or more of the calves were graded. The fact that all lambs and calves were not graded was accounted for primarily by such factors as the limited number of animals brought in at non-seasonal times, and the desire on the part of some consignors to have their livestock sold separately or on a basis differing from that of established state grades.

Auction operators expressed the opinion that buyers showed more interest in the grading of livestock than did producers. In fact, many of the larger packer-buyers insist on grading if they are to enter the market, since thereby they have assurance that they will be able to buy livestock on a quality basis. While farmers have been slower to accept grading, there are indications that they are looking with more favor on this practice. Less grading is done at small auctions than at large ones. This is primarily due to the fact that the available market outlets do not justify grading. A larger proportion of livestock sold through small auctions was bought by local killers and packers, and these buyers were in position to take only a limited number of each grade. Consequently, they desired to "pick" individual animals or small lots as they came into the ring. Auction operators also reported that some consignors objected to grading and selling livestock by lots on the ground that this did not permit individual consignors to protect their own livestock by bidding on it when prices were not satisfactory.

There has been no particular trend in the proportion of various grades of lambs sold at auction markets (Fig 17). ${ }^{21}$ Variations, however, do occur. For example, the proportion of choice and good lambs in 1941 was at least $12 \frac{1}{2}$ percent higher than for any previous year. Further consideration of the data presented in Fig. 17 indicates that similar though less significant trends existed for cooperative livestock marketing associations.

As reported for 12 auction markets in 1941, the distribution of veal

21Reported by the auctions grading lambs and veal calves. The number of auctions grading has varied from 8 to 12 during 1938-1941. 
calves according to grade was as follows:

\begin{tabular}{lc} 
Grade & $\begin{array}{c}\text { Percentage of total } \\
\text { percent }\end{array}$ \\
Prime & 8.7 \\
Choice & 25.1 \\
Gcod & 38.7 \\
Medium & 17.3 \\
Common & 4.0 \\
Culls & 0.5 \\
Unclassified & 5.7 \\
\multicolumn{1}{c}{ Total } & - \\
& 100.0
\end{tabular}

Variation in established grades of veal calves makes it impossible to obtain comparable data relating to trends in the proportion of various grades sold. Some improvement in the quality of calves graded at auctions, however, is evident. For instance, only 55 percent of all calves graded good or better in 1939 as compared with 73 percent in 1941 .

Yearly prices received for various grades of lambs and veal calves are shown in Table 23. It is evident that, along with cooperative associations, auction markets are definitely bringing about a situation in the state whereby many farmers are paid in accordance with the quality of livestock they produce. The fact that choice lambs and choice veal calves bring around twice that received for cull grades is indicative of the tendency to pay according to quality and to break away definitely from the practice of buying livestock on the basis of "averages."

It has been indicated that data were not available for a detailed comparison of prices obtained by cooperative associations and auction markets. This was especially true when average prices for all grades were considered, because all costs involved in the operation of cooperatives were not known. Furthermore, cooperative associations reported a slightly higher proportion of choice and good lambs. A comparison of prices for various lamb grades as obtained by cooperative associations and auction markets, however, furnishes significant information. Averages of a $n \mathrm{nu}$ a 1 lamb prices for the period 1938-1941 were reported as follows:

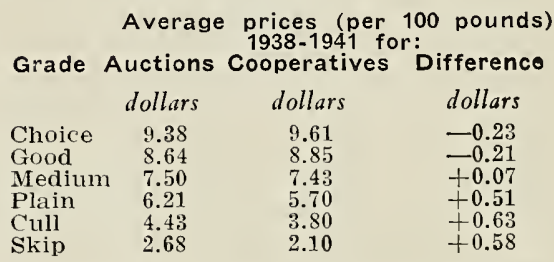

Based on the assumption that lambs marketed through auctions and cooperative associations are identical, grade for grade, data indicate that, as a general rule, cooperative associations have obtained higher prices than auctions for the higher grades of lambs (choice and good), and auctions have obtained higher prices for the lower grades of lambs (medium, plain, cull, and skip).

That this fact seemed to be recognized by farmers was evidenced by the relatively greater proportion of all lambs grading plain or lower that were sold through auction markets as compared with cooperative asscciations. For the period 1938. 1941 this comparison was as follows:

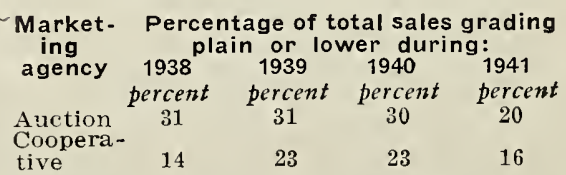

That prices for lower grades of lambs were relatively higher at auctions than at cooperatives also was indicated by a comparison of price differentials according to grade. Since prices at auctions were higher than cooperative prices for the lower grades, price differentials for auctions naturally would be less. These differentials were as follows: 
Price differentials (per 100 pounds) average 1938-1941 for:

$\begin{array}{lccc}\begin{array}{c}\text { Grade } \\ \text { comparison }\end{array} & \begin{array}{c}\text { Auc- } \\ \text { tion } \\ \text { dollars }\end{array} & \begin{array}{c}\text { Coopera- } \\ \text { tive } \\ \text { dollars }\end{array} & \begin{array}{c}\text { Differ- } \\ \text { ence } \\ \text { dollars }\end{array} \\ \begin{array}{cccc}\text { Choice over } \\ \text { good }\end{array} & +0.74 & +0.76 & -0.02 \\ \begin{array}{c}\text { Good over } \\ \text { medium }\end{array} & +1.14 & +1.42 & -0.28 \\ \begin{array}{c}\text { Medium over } \\ \text { plain }\end{array} & +1.29 & +1.73 & -0.44\end{array}$

This suggests that farmers, when they have lambs of different grades to sell, may do well to utilize different market agencies. It also indicates that cooperative associations might increase their service to farmers if they utilized those market outlets that paid highest prices for lowgrade lambs. Such service by cooperative associations would save farmers the trouble of taking lambs to various market agencies. By handling larger quantities of lambs, cooperatives also could take advantage of the usual discounts for quantity consignments.

It seems impossible to determine to what extent the price advantages and disadvantages for each marketing agency may be due to possible differences in grade, prices on the day sold, m a rket outlets, predetermined differentials be tw e e $n$ grades (in the case of cooperatives), and method of selling (whether at auction or direct to a national packer). It is suggested that both auctions and cooperative managers may find it possible to improve price relationships and to secure further advantage for their patrons.

Order of Sale: The order of sale followed by livestock auctions varied appreciably. The more important considerations that either determined or influenced sales order were: (1) desire to rotate sales in order to equalize opportunities for producers and buyers of various species and classes of livestock, (2) convenience of buyers, (3) train connections, and (4) seasonal distribution of livestock.

As a general rule, non-livestock items were sold first. They were followed by poultry, horses, and other odd classes of livestock. Several auctions followed with sales of hogs, sheep, calves, and, lastly dairy and beef cattle. Some auctions have

Table 23-Prices Received Per 100 Pounds for Lambs and Veal Calves, According to Grade, as Reported for Sales Through Livestock Auctions in West Virginia, 1938-1941 ${ }^{1}$

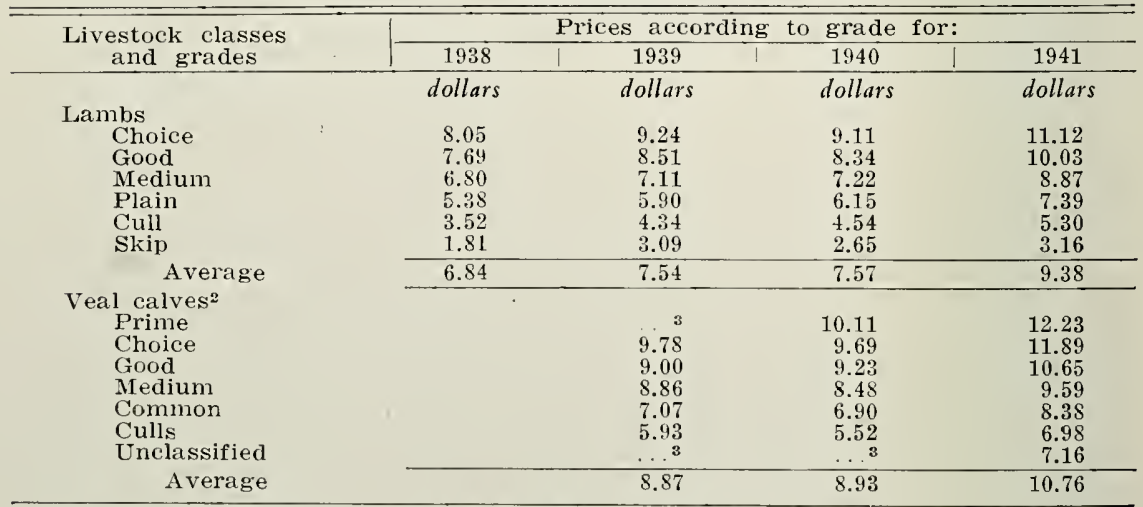

1 Reported by the auctions grading lambs and veal calves. The number of auctions grading has varied from 8 to 12 for different years.

${ }^{2}$ Auctions did not start grading veal calves until 1939.

"Grades not used during 1939 and 1940. 
developed the practice of selling rather early, livestock likely to go back to the farm, as an accommodation to the farmers. Other auctions have found it advisable to arrange the order of sales for the convenience of buyers of slaughter animals.

Selling Charges: The maximum commissions charged for various classes of livestock are given in $\mathrm{Ta}$ ble 24. The common practice among auction operators is to charge onehalf the usual commission when consignors bid in their own livestock. In an effort to discourage pinhookers, some auctions have started the practice of charging them the usual commission whenever they are able to do so.

Auctions charged much the same commission for various classes of beef and dairy cattle and, except for cow-and-calf combinations, the usual commission was $\$ 1$ per head. Most auctions offered special rates for carload lots, usually $\$ 18$ to $\$ 20$ per car. In addition the usual practice for auctions charging $\$ 1$ per head was to $\mathrm{r}$ ed uce commisssions to around 75 cents per head when consignments were in lots of three, four, five, or more head.

Considerable variation, depending upon sales price, existed in the commissions charged for horses. While the usual practice was to charge a maximum rate of $\$ 2$ per head, some rates were on a graduated basis. One auction has worked up a schedule of charges ranging from $\$ 2$ for a value of less than $\$ 50$ to $\$ 5$ for values of more than $\$ 200$.

The usual commission for calves (veal or feeder) was 50 cents per head, with a few auctions maintaining a fee of 25 cents per head. The common practice was to consider animals as calves up to a weight of 400 pounds and as feeder stock or slaughter animals when over this

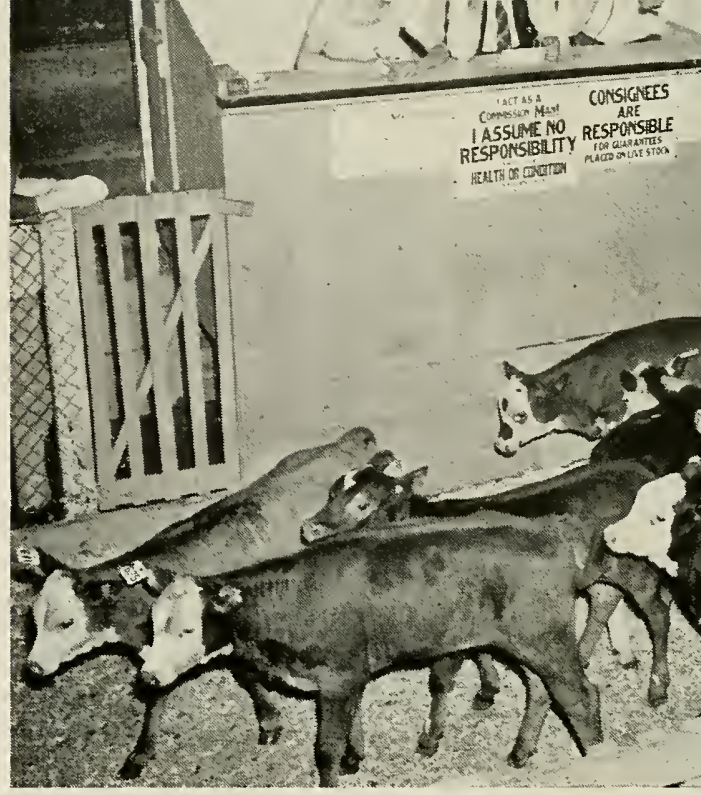

\section{Fig. 20-Sales Ring Activities at Auction Markets}

DEPENDING UPON THE CLASS OF LIVESTOCK, AUCTION PRACTICES, AND THE WISH OF CONSIGNORS, LIVESTOCK IS SOLD SEPARATELY, IN LOTS OF ACCORDING TO ESTABLISHED STATE AND FEDERAL GRADES

weight limit.

Sheep and lamb commissions were 25 cents per head or less at all auctions but one. A common practice was to charge 5 cents less per head for lambs than for mature sheep. The fact that lambs frequently were sold in large lots helps account for this variation in price. A few auctions report carlot rates for lambs in addition to the practice of "shaving" commission charges a nickel for lots ( 5 to 50 head or more).

Except for the tendency of a few auctions to charge 50 cents commis sion per head for butcher hogs, little difference existed in the sales charges made for sheep and hog's. One auction, however, sold slaughter hog's on a weight basis $(20$ cents per 100 pounds for lots of 5 or less and 15 cents per 100 pounds for lots of over 5). Special rates also were frequently used for sow and pig com- 
binations, the rate varying from $\$ 1$ to $\$ 1.50$, according to the auction ard the value of sales.

In addition to commissions, all auctions in the state have adopted the practice of making an "insurance" or "service" deduction of onehalf of one percent of sales value. While this deduction was theoretically supposed to cover losses of livestock, these losses have been negligible. In effect this item has amounted to an additional source of income for auction markets.

Price-maintenance Policies: A wide variety of practices was used by livestock auction markets to maintain prices. Approximately one-half of the auctions reported that managers bid on livestock. Such bidding was done either in his own name or in the name of the auction. It was the definite practice of a few auctions to support prices in order to prevent some buyers from "stealing the stuff." Other yards had agreements with helpers and dealers to bid on livestock if necessity demanded. Still other auctions attempted to remedy the situation by aggressively hunting buyers. In some instances they have paid buyers' expenses to attend sales and have made special efforts to see that the kind of livestock that buyers desired was available. Quite properly, some auction operators point out that, if desirable relations are to be maintained with buyers, it is not advisable to "try for the last dime." In other words, it is not good policy to take advantage of a temporary market situation if by so doing there is no incentive for buyers to return. Another problem that deserves careful consideration, especially among the small auctions, is that of collusion among buyers. To break up such practices is essential if the auction is to maintain satisfaction among consignors. This necessitates steps that will aid buying competition. These often take the form of bringing in new buyers or engaging in the less satisfactory practice of actual price support by auction markets.

For the auction to enter the mar-

Table 24-Maximum Commission Charges Per Individual Animal as Reported by 21 Auctions in West Virginia, 1939

\begin{tabular}{|c|c|c|c|c|c|c|c|c|c|}
\hline \multirow[b]{2}{*}{$\begin{array}{l}\text { Species and class } \\
\text { of livestock }\end{array}$} & \multirow{2}{*}{\multicolumn{2}{|c|}{$\begin{array}{l}\text { Auctions } \\
\text { reporting }\end{array}$}} & \multicolumn{7}{|c|}{ Prices charged per animal } \\
\hline & & & $\begin{array}{c}50 \\
\text { cents }\end{array}$ & $\begin{array}{c}75 \\
\text { cents }\end{array}$ & $\begin{array}{c}80 \\
\text { cents }\end{array}$ & $\$ 1.00$ & $\$ 1.25$ & $\$ 1.50$ & $\$ 2.00$ \\
\hline \multirow{2}{*}{\multicolumn{10}{|c|}{ number of auctions }} \\
\hline & & & & & & & & & \\
\hline \multicolumn{2}{|l|}{$\begin{array}{l}\text { Steers } \\
\text { Fat cows and heifers }\end{array}$} & 21 & 1 & 1 & 2 & 16 & $\cdots$ & 1 & $\because$ \\
\hline \multicolumn{2}{|l|}{$\begin{array}{l}\text { Cull } \\
\text { Dairy a cattle }\end{array}$} & 21 & 1 & 1 & 2 & 16 & $\because$ & 1 & $\because$ \\
\hline \multicolumn{10}{|l|}{ Dairy cattle } \\
\hline \multicolumn{2}{|l|}{$\begin{array}{l}\text { Milk and breeding } \\
\text { Cull }\end{array}$} & $\begin{array}{l}17 \\
19\end{array}$ & 1 & 1 & $\frac{2}{2}$ & 12 & $\cdots$ & 1 & $\cdots$ \\
\hline \multirow{4}{*}{$\begin{array}{l}\text { Cow and calf (beef or d } \\
\text { Horses }\end{array}$} & lairy) & 13 & & & & $\begin{array}{r}14 \\
2\end{array}$ & $\ddot{5}$ & 6 & $\cdots$ \\
\hline & & 15 & & & & .. & 3 & 2 & 10 \\
\hline & & & \multicolumn{7}{|c|}{ Prices charged per animal } \\
\hline & & & $\begin{array}{c}15 \\
\text { cents }\end{array}$ & $\begin{array}{l}20 \\
\text { cents }\end{array}$ & $\begin{array}{c}25 \\
\text { cents }\end{array}$ & $\begin{array}{c}30 \\
\text { cents }\end{array}$ & $\begin{array}{c}35 \\
\text { cents }\end{array}$ & $\begin{array}{c}40 \\
\text { cents }\end{array}$ & $\begin{array}{c}50 \\
\text { cents }\end{array}$ \\
\hline & \multicolumn{6}{|c|}{ number of auctions } & \\
\hline $\begin{array}{l}\text { Calves } \\
\text { Veal }\end{array}$ & & 18 & & & 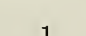 & & & & \\
\hline Feeder & & 21 & . & & $\frac{1}{4}$ & : & $\because$ & $i$ & $\begin{array}{l}17 \\
16\end{array}$ \\
\hline \multicolumn{2}{|l|}{$\begin{array}{l}\text { Sheep and lambs } \\
\text { Lambs }\end{array}$} & & & & & & & & \\
\hline \multicolumn{2}{|l|}{$\begin{array}{l}\text { Lambs } \\
\text { Breeding sheep }\end{array}$} & $\begin{array}{l}21 \\
16\end{array}$ & 5 & 11 & 4 & . & 1 & . & . \\
\hline Rams (when specia) & & $\begin{array}{r}10 \\
3\end{array}$ & 1 & $\begin{array}{l}0 \\
.\end{array}$ & 10 & $\because$ & $\because$ & $\because$ & $\ddot{z}$ \\
\hline Hogs & & & & & & & & & \\
\hline \multicolumn{2}{|l|}{$\begin{array}{l}\text { Butcher } \\
\text { Feeder }\end{array}$} & 18 & 4 & 5 & $\begin{array}{r}12 \\
8\end{array}$ & $i$ & 2 & . & 5 \\
\hline
\end{tabular}


ket directly or through its employees renders it subject to criticism both by buyers and sellers. Buyers are inclined to feel that such activity mierely pushes prices up for them and means that they are forced to pay more than ctherwise would be the case. On the other hand, consignors are inclined to believe that this practice gives auctions or auction operators an additional "cut" when they purchase an appreciable share of the livestock going through the ring. When these operators happen to own or have an interest in local slaughter piants, or regularly ship carload lots, there seents to be considerable basis for objection to such practices.

Auctions should take every precaution to prevent employees from dealing on their own account. If they desire to handle "order bids," it may be to the advantage of auction markets to set up an independently operated brokerage department or ccncern to handle such sales and purchases. If this is done, definite steps should be taken to have all such sales and purchases handled by such an agency. Furthermore, if this practice should be adopted, auctions would find it advisable to acquaint both buyers and sellers with the manner in which such brokerage activities are carried out.

In order to facilitate the handling of livestock, some auctions have arranged to have the auctioneer or manager start the bidding. This may save time, and if those engaging in the practice are good judges of livestock values, they will start bids in such a manner that market prices are in no way influenced.

Three practices were followed to enable consignors to obtain price protection. They were permitted to bid on their own stock or to have auction employees bid on it (one auction reported that it did not permit this practice); or they set a minimum price on the consignment slip, "no sale" being announced by auctioneers if this price was not reached. In actual practice, certain abuses may occur when the latter practice is followed. Dealers or pinhookers may take advantage of every opportunity to "punch their own stuff up" to the limit whenever market conditions so warrant. Some farmers on the other hand complained that the minimum price tended to become the maximum price and that at some auctions this condition resulted because livestock was sold to "insiders" when the minimum price set by farmers was below market value.

Auctions in West Virginia did not follow the practice of guaranteeing the condition of the livestock sold. Consignors' statements concerning condition and quality frequently were read by the auctioneer, and often it was arranged to hold checks until buyers had had sufficient time tc try out the livestock purchased. It should be emphasized that under such conditions, validity of the statement was no better than the individual giving it. This was well put by one auction manager who stated that "there never was a dairy cow sold on a livestock auction that did not give three gallons of milk a day."

Emplcyees: Managers of livestock auctions are, in most instances, graduates from the local livestock dealer profession. Five auctions reported that their managers combined seneral farming with their auction activities, and three operators were listed as local businessmen. In practically every instance, however, they also had many years of experience in the livestock business.

While a few managers limited their activity to the day of the sale, the usual practice was to devote one to three additional days per sale to this job. In one instance the man- 
ager is a full-time employee. The nature of the work consisted of helping with or supervising accounting and record work on the day following sale, soliciting and in some instances "pricing" livestock, contacting and soliciting buyers, and occasionally attending other sales.

The general feeling among auction managers was that it would be to their advantage to spend more time in field work, although one reported that the practice of pricing cattle had degenerated into a racket and was used by potential consignors to play one auction or sales agency against another.

Information was obtained relative to the trading activities of auction managers. Previous mention has been made of the undesirable consequences of permitting auction managers to trade in livestock for themselves and at the same time manage sales for others. However, this continued to be a common practice as may be seen from the following data:

$\begin{array}{lcc}\begin{array}{c}\text { Kind of } \\ \text { trading } \\ \text { practice }\end{array} & \begin{array}{c}\text { Number of auctions report- } \\ \text { ing on manager trad- } \\ \text { ing practices } \\ \text { engaged in not engaged in }\end{array} \\ \begin{array}{c}\text { Buying in } \\ \text { the country }\end{array} & 16 & 3 \\ \begin{array}{c}\text { Buying at } \\ \text { auctions }\end{array} & 14 & 5 \\ \begin{array}{c}\text { Selling at } \\ \text { auctions }\end{array} & 13 & 5\end{array}$

Livestock auctioneers in West Virginia appear to have grown up in the auctioneering business. Most auctioneers were hired on the basis of a certain fee per sale. Some of the larger auctions employed two auctioneers, especially during the peak season. The usual pay varied from $\$ 10$ to $\$ 25$ per sales day.

Fifteen auctions reported that auctioneers announced the buyer. Some of the auctions, however, indicated that this practice was not strictly adhered to. In addition, four auctions reported that it was their policy not to announce buyers. Both buyers and consignors would tend to have more confidence in the validity of auction transactions if special efforts were made to announce buyers.

Although the state law prohibits auctioneers from having a financial interest in livestock auctions and from trading in livestock at the auction where they work, it was reported that this regulation was not rigidly complied with. It would appear, however, that auctioneers are not in position to get the consignor the highest possible price if they are influenced by a desire to obtain stock for themselves or colleagues, at prices that would result in profit, or if they are inclined at other times to put more effort into the sale of their own stock than the stock of other consignors.

\section{PUBLICITY}

Of the 21 auctions reporting on publicity, 18 indicated that they made definite efforts to obtain publicity of sales activities. Local papers in the territories served by auctions (varying in number from 3 to 20 ) carried information relating to such items as number of head according to species and class, prices, and general market conditions. In addition some auctions have built up mailing lists that cover much the same gen$€$ ral information that is carried by newspapers. Cards to buyers stress the amount and quality of livestock available. Two auctions reported the use of radio broadcasting in their publicity work. The common practice was to announce numbers of head of livestock received, prices paid, and general market conditions. Those auctions not using any methods of publicity reported that the results were known within 100 miles on the day of the sale because of dealer and trucking activities.

Farmers have expressed dissatisfaction with the publicity methods. 
It was common opinion that some auctions followed the practice of taking out a few top animals in each class to sell separately. If these animals did not bring the price desired through normal channels of trade, it was reported that the price was bid up to establish a top price for quotation purposes. While this practice is less common than previously, its use has not been entirely discontinued. Progressive auction operator's are beginning to realize, however, that satisfaction depends upon performance. The final test of auction performance is greater net income from all sales for all classes of animals than can be obtained through any other marketing agency.

\section{REGULATION AND SUPERVISION}

\section{Bonding and Financial Responsi-} bility of Traders: In compliance with state law, all auctions in West Virginia are bonded. Provisions of the law require that all auctions be bonded to the extent of average weekly sales for the preceding years. These provisions have proved satisfactory; to date there have been no reported losses experienced by consignors because of lack of financial responsibility on the part of livestock auctions. Eleven auctions were bonded for $\$ 5,000$ or less, five for $\$ 5,001$ to $\$ 10,000$, and three for $\$ 10,001$ or more.

Auction operators reported some difficulty in checking on the responsibility of traders. The common practice was to call banks or business establishments that were acquainted with the trader. Another practice was to have new traders furnish references or obtain identification from acquaintances at the auction. Auction operators, however, reported that their chief difficulty was with dealers who had established credit ratings. Some of them lacked stability and any unforeseen circum- stances might force them to discontinue business operations or go into bankruptcy. The danger of this situation could be lessened by the enactment of a state law providing for the bonding of all dealers purchasing livestock in specified amounts.

Sanitation: The West Virginia auction law provides that, for all livestock going back to farms, cattle must be blood-tested for abortion and vaccinated for blackleg, sheep dipped for scab, and hogs vaccinated for cholera. A licensed veterinarian, approved by the state, is assigned to each auction. The state furnishes the necessary vaccine at cost. In 1939 standard charges were 50 cents per animal for blood tests. Three auctions reported sheep dipping charges of 10 cents per head, seven of 15 cents, two of 20 cents, and one charged $12 \frac{1}{2}$ cents per head for lots of less than 10 , and 10 cents for lots of over 10. Hog cholera vaccination charges were in accordance with the amount used, varying from around 35 cents for a 100 pound hog to 60 cents for 200 pound animals.

The provisions of the West Virginia idw are generally satisfactory. Where difficulty occurred it usually could be traced to certain violations by misinformed or unscrupulous opcrators. For example, dealers occasionally were permitted by auction operators to use scales for weighing livestock and then to take such livestock directly to farms. Furthermore, four auctions reported that they had no facilities for dipping sheep, yet sheep at times left their yards to go back to farms.

Auction operators reported that at times they have had difficulty in convincing farmers of the merits of the sanitary precautions taken and of the justification of the charges they were forced to make to cover them. To many, however, the won- 


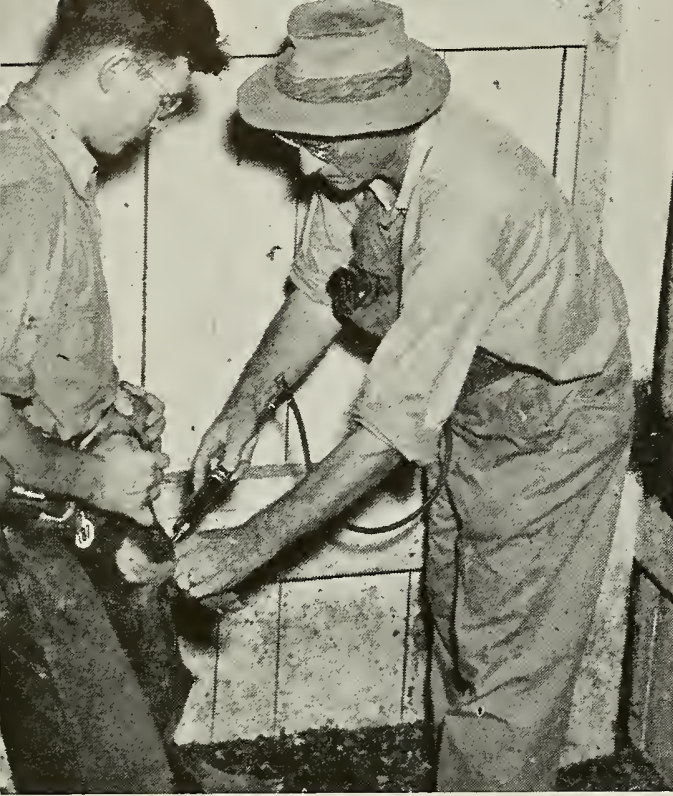

Fig. 21-Sanitary Precautions Taken at West Virginia Auctions

der was that farmers buying at sales did not insist that precautions be taken to insure the health of animals taken back to their farms. It must be recognized that whenever large numbers of livestock are mingled, the possibility of spreading disease increases.

Farmers reported that in other instances, such ailments as pinkeye and shipping fever have been prevalent in auction stock. Some managers reported that "other" auctions have experienced considerable difficulty at times. General precautions taken usually included cleaning pens and sprinkling lime. Improvements in the location and drainage of pens and installation of concrete floors offer the best possibilities for better sanitary conditions. The sanitation problems of auctions were summarized by one operator with the statement, "Don't kid yourself, discase is a serious problem." It is not fair, however, to charge auctions with the responsibility for all disease in animals moving through their yards. In some instances they were infected during transit.

\section{CONSIGNORS AND BUYERS}

The proportion of livestock consigned and purchased by various types of market dealers is of interest to operators, farmers, and agencies utilizing the auction system of marketing. Accordingly, auction operators were asked to furnish estimates of the proportion of various species of livestock consigned and purchased by different types of market dealers.

Consignors: In West Virginia, farmers and local dealers consigned all livestock sold through auctions. Some livestock was consigned by auction operators. When engaged in such business, however, they functioned primarily as local dealers. In a few instances the proportion of such consignments was of some importance, but for all auctions it probably did not account for more than 5 percent of sales.

There was no significant differ $€$ nce in the proportion of feeder, breeding, and slaughter livestock consigned by farmers and dealers. For all classes and species of stock, except horses, the proportion consigned by farmers ranged from 72 to 80 percent of the total. The percentage distribution of numbers of various species of livestock consigned by farmers and dealers is indicated in Figure 22.

Buyers: Considerable variation existed in the proportion of livestock purchased by various market dealers. Principal buyers were packers, local dealers, and farmers. There were two classes of packers, large and small. The large packers in- 
cluded national packers and large independent packing concerns. "Small packers" primarily refers to small independent packing establishments in Orio and Pennsylvania and to local packing plants in West Virginia. A limited number of livestock buyers could not readily be classified. Local butcher shops, however, accounted for a large proportion of the business of such agencies. These establishments were particularly important as outlets for cull cattle and slaughter hogs.

While the data presented in Fig. 22 apply to all livestock bought, considerable difference exists as to the agencies buying feeder and breeding stock. As would be expected, such livestock was purchased primarily by farmers and to a lesser extent by local dealers. The percentage distribution of feeder and breeding stock according to livestock species was reported for types of buyers as follows :

\begin{tabular}{cccc}
$\begin{array}{c}\text { Livestock species } \\
\text { and class } \\
\text { (Feeder and } \\
\text { breeding) }\end{array}$ & $\begin{array}{c}\text { Percentage of total } \\
\text { purchased by: } \\
\text { Farm- } \\
\text { ers ocal Unclass- } \\
\text { deal- } \\
\text { ified } \\
\text { agencies }\end{array}$ \\
Cattle & \multicolumn{3}{c}{$\begin{array}{c}\text { percent } \\
\text { percent percent }\end{array}$} \\
Calves & 76 & 23 & 1 \\
Swine & 78 & 20 & 2 \\
Sheep and lambs & 72 & 22 & 6 \\
& 65 & 30 & 5
\end{tabular}

\section{ANALYSIS OF OPERATING STATEMENTS}

Consolidated operating statements for livestock auctions are presented in Table 25. The term "net to consignors" and "operating income" are net items after all needed adjustments are made for refunds on commissions and similar items. Included in operating income are insurance or service charges which account for between 0.50 and 0.54 of a cent per dollar of sales. This represents an amount equivalent to between onefifth and one-sixth of the operating income of livestock auctions and is an item only slightly less than the net income reported for all auctions. (Items included in operating exjenses are shown in Table 26.) "Other income" includes receipts from the operation of restaurants, commissions from the sale of a limited number of animals (usually horses) that do not go through the ring, and other miscellaneous receipts. "Other expenses" include interest paid and such other items as are not directly connected with auction operation.

For all auctions, consignors received slightly over 97 percent of the gross sales reported. Operating income was just slightly less than 3 cents per dollar of sales, and operating expense in turn was just under $2 \frac{1}{2}$ cents. Net income averaged 0.63 cent per dollar of sales.

Comparison of average operating statements for auctions classified according to size and type of farming area indicates that the larger auctions returned about one-half cent more per dollar of sales to consignors and operated at a cost of about one-half cent less per dollar of sales. Net income was 0.71 cents per dollar of total sales for the larger auctions as compared with 0.46 cents for the smaller ones. Livestock auctions in the central livestock area returned about one-half cent less per dollar of total sales to consignors than did auctions in the eastern livestock region. The average operating income in terms of dollar sales for auctions in the dairy and general farming area was approximately midway between the other two classifications. Expenses for auctions in the central livestock area were about one-half cent less per dollar of total sales than for auctions in the dairy and general farming regions with auctions in the eastern area about midway between these classifications.

It may be observed that auctions in the two livestock areas (eastern 
CATRE

CALVES

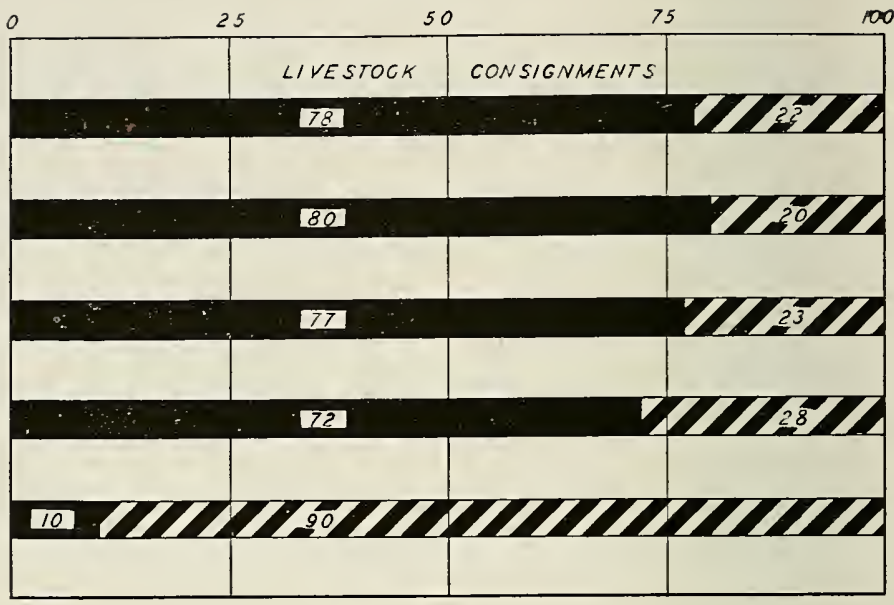

GATILE

CALVES

SHEEP AND LAMBS

SWINE

HORSES
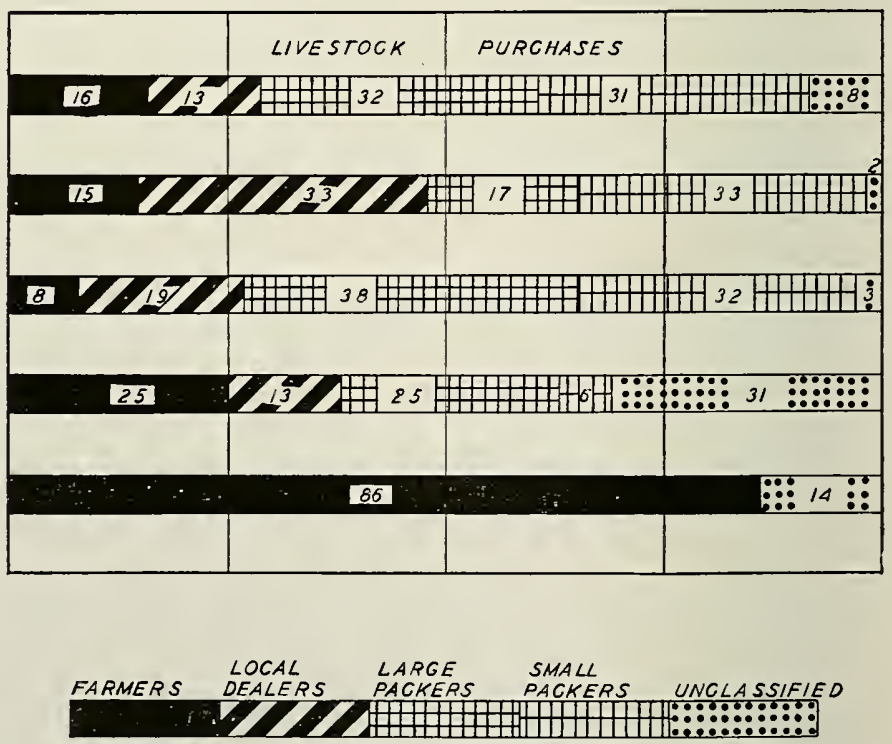

Fig. 22-Sales and Purchases According to Types of Consignors and Buyers, as Reported by Livestock Auction Operators in West Virginia, 1939 
and central) operated with a yearly ret income of about three-fourths of a. cent per dollar of total sales and those in the dairy and general farming area reported a net income of only one-third of a cent per dollar of total sales. Expressed another way, net income amounted to 26.74, 23.16 , and 11.01 percent, respectively, of operating income for auctions in the central livestock, eastern livestock, and dairy and general farming areas.

The distribution of expense items for all auctions and for auctions classified as to size and type of farm- ing region is presented in Table 26 . It may be noted, that wages, bonuses, and salaries accounted for approxiviately one-half of total expenses. Officers' and directors' salaries acccunted for another one-tenth of total expenses, making a combined total of about 60 percent of the total expenses for all salaries and wages. Except for taxes, the next most im. portant item was operating and trading loss. This item included losses on stock because of death or crippling, mix-ups in consignment and sales slips, and losses resulting from efforts to support market prices or

\section{Table 25-Average Operating Statements Expressed in Dollars, Percentage of Total Sales, and Percentage of Operating Income, Classi- fied According to Size of Business and to Type of Farming Area Served, as Reported by 10 Live- stock Auctions in West Virginia, 1939}

\begin{tabular}{|c|c|c|c|c|c|c|c|c|c|}
\hline \multirow{4}{*}{ Item } & \multirow{2}{*}{\multicolumn{3}{|c|}{$\begin{array}{l}\text { Average all } \\
\text { auctions }\end{array}$}} & \multirow{2}{*}{\multicolumn{6}{|c|}{$\begin{array}{c}\text { Average acccrding to annual sales } \\
\begin{array}{c|c}\text { Over } \$ 500,000 & \$ 500,000 \text { or less } \\
\text { (4 auctions }) & (6 \text { auctions })\end{array}\end{array}$}} \\
\hline & & & & & & & & & \\
\hline & \multirow[b]{2}{*}{ Amount } & \multicolumn{2}{|c|}{$\begin{array}{c}\text { Peicentage } \\
\text { of: } \\
\end{array}$} & \multirow[b]{2}{*}{ Amount } & \multirow{2}{*}{\multicolumn{2}{|c|}{$\mid$\begin{tabular}{c|}
$\begin{array}{c}\text { Peicentage } \\
\text { of: }\end{array}$ \\
$\begin{array}{c}\text { Total } \\
\text { sales }\end{array}$ \\
$\begin{array}{c}\text { Oper- } \\
\text { ating } \\
\text { in- } \\
\text { come }\end{array}$
\end{tabular}}} & \multirow[b]{2}{*}{ Amount. } & \multicolumn{2}{|c|}{$\begin{array}{l}\text { Pticentage } \\
\text { of: }\end{array}$} \\
\hline & & $\begin{array}{l}\text { Total } \\
\text { sales }\end{array}$ & $\begin{array}{l}\text { Oper- } \\
\text { ating } \\
\text { in- } \\
\text { come }\end{array}$ & & & & & $\begin{array}{l}\text { Tota] } \\
\text { sales }\end{array}$ & $\begin{array}{l}\text { Oper- } \\
\text { ating } \\
\text { in- } \\
\text { come }\end{array}$ \\
\hline \multirow{2}{*}{$\begin{array}{l}\text { Gross sales } \\
\text { Net to } \\
\text { consignors }\end{array}$} & $\begin{array}{l}\text { dollars } \\
495,422\end{array}$ & $\begin{array}{l}\text { percent } \\
100.00\end{array}$ & percent & \multicolumn{6}{|c|}{ 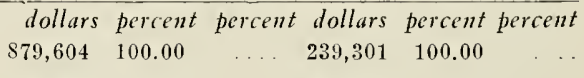 } \\
\hline & 481,213 & 97.13 & & 855,550 & 97.27 & & 231,656 & 96.81 & \multirow[b]{2}{*}{100.00} \\
\hline \multirow{2}{*}{$\begin{array}{l}\text { Operating } \\
\text { income } \\
\text { Operating } \\
\text { expenses }\end{array}$} & 14,209 & 2.87 & 100.00 & 24,054 & 2.73 & 100.00 & 7,645 & 3.19 & \\
\hline & 11,937 & 2.41 & 84.01 & 19,662 & 2.23 & 81.74 & 6,788 & \multirow{3}{*}{$\begin{array}{l}2.84 \\
0.11\end{array}$} & \multirow{3}{*}{$\begin{array}{r}88.79 \\
3.35 \\
0.18\end{array}$} \\
\hline \multirow{3}{*}{$\begin{array}{l}\text { Other income } \\
\text { Othe' expenses } \\
\text { Net income }\end{array}$} & 912 & 0.18 & 6.42 & 1,897 & 0.22 & 7.89 & 256 & & \\
\hline & 40 & 0.01 & 0.28 & 77 & 0.01 & 0.32 & 14 & & \\
\hline & 3,144 & 0.63 & 22.13 & 6,212 & 0.71 & 25.83 & 1,099 & 0.46 & $14 . \overline{38}$ \\
\hline \multirow{4}{*}{ Item } & \multicolumn{9}{|c|}{ Average according to type of farming area } \\
\hline & \multicolumn{3}{|c|}{$\begin{array}{l}\text { Eastern livestock } \\
\quad(3 \text { auctions })\end{array}$} & \multicolumn{3}{|c|}{$\begin{array}{c}\text { Central livestock } \\
\text { (5 auctions) }\end{array}$} & \multicolumn{3}{|c|}{$\begin{array}{l}\text { Dairy and general } \\
\text { farming } \\
\text { (2 auctions) }\end{array}$} \\
\hline & \multicolumn{3}{|c|}{$\begin{array}{c}\text { Pércentage } \\
\text { of: }\end{array}$} & \multicolumn{3}{|c|}{$\begin{array}{c}\text { Pcicentage } \\
\text { of: }\end{array}$} & \multirow[b]{2}{*}{ Amount } & \multicolumn{2}{|c|}{$\begin{array}{c}\text { Pt'icentage } \\
\text { of: }\end{array}$} \\
\hline & Amount & $\begin{array}{l}\text { Tota] } \\
\text { sales }\end{array}$ & $\left|\begin{array}{c}\text { Oper- } \\
\text { ating } \\
\text { in- } \\
\text { come }\end{array}\right|$ & Amount & $\begin{array}{l}\text { Total } \\
\text { sales }\end{array}$ & $\begin{array}{l}\text { Oper- } \\
\text { ating } \\
\text { in- } \\
\text { cone }\end{array}$ & & \multicolumn{2}{|c|}{ 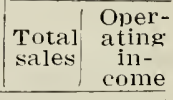 } \\
\hline \multirow{2}{*}{$\begin{array}{l}\text { Gross sales } \\
\text { Net to } \\
\text { consignors }\end{array}$} & \multicolumn{3}{|c|}{$\begin{array}{l}\text { dollars percent percent } \\
242,970 \quad 100.00\end{array}$} & $\begin{array}{cc}\text { dollars } \\
602,847\end{array}$ & $\begin{array}{l}\text { percent } \\
100.00\end{array}$ & percent & $\begin{array}{l}\text { dollars } \\
605,538\end{array}$ & $\begin{array}{l}\text { percent } \\
100.00\end{array}$ & percent \\
\hline & 235,157 & 96.78 & & 586,376 & 97.27 & & 587,391 & 97.00 & \\
\hline $\begin{array}{l}\text { Operating } \\
\text { income } \\
\text { Operating }\end{array}$ & 7,813 & 3.22 & 100.00 & 16,471 & 2.73 & 100.00 & 18,147 & 3.00 & 100.00 \\
\hline expenses & 6,131 & 2.52 & 78.47 & 13,602 & 2.26 & 82.58 & 16,485 & 2.72 & 90.84 \\
\hline $\begin{array}{l}\text { Other income } \\
\text { Other expense }\end{array}$ & $\begin{array}{r}156 \\
29\end{array}$ & 0.06 & 2.00 & 1,559 & 0.26 & 9.47 & 431 & 9.07 & 2.37 \\
\hline $\begin{array}{l}\text { Other expense } \\
\text { Net income }\end{array}$ & 29 & 0.01 & 0.37 & 24 & & & 95 & 0.02 & 0.52 \\
\hline Net income & 1,809 & 0.75 & 23.16 & 4.404 & 0.73 & 26.74 & 1,998 & 0.33 & 11.01 \\
\hline
\end{tabular}


from attempts to make money for the auction by buying livestock. It is significant that in practically every irstance, auctions lost money on their trading operations. This does not mean, however, that persons connected with auctions lost money when operating as individuals. Other important expense items were depreciation, office supplies, and utilities.

The relatively high proportion of gross sales returned to consignors in- dicates that livestock auctions do a reasonably efficient job of bringing buyers and sellers together. In very few instances do the charges mäde cover any of the costs of transporting livestock to the auction and the time involved in "seeing the stock through the ring." Furthermore, it should be pointed out that the auction system of livestock marketing niay break into the livestock chan.

\section{Table 26-Average Operating-Expense Statements, Expressed in Dollars and in Percentage of Total Expenses, Classified According to Size of Business and to Type of Farming Area Served, as Reported by 10 Livestock Auctions in West Virginia, 1939}

\begin{tabular}{|c|c|c|c|c|c|c|}
\hline \multirow{3}{*}{ Item } & \multirow{2}{*}{\multicolumn{2}{|c|}{$\begin{array}{l}\text { Arerage all } \\
\text { auctions }\end{array}$}} & \multicolumn{4}{|c|}{ Average according to annual sales } \\
\hline & & & \multicolumn{2}{|c|}{$\begin{array}{l}\text { Over } \$ 500,000 \\
(4 \text { auctions })\end{array}$} & \multicolumn{2}{|c|}{$\begin{array}{c}\$ 500,000 \text { or less } \\
(6 \text { auctions })\end{array}$} \\
\hline & \multicolumn{2}{|c|}{\begin{tabular}{c|c} 
Percentage \\
Amount
\end{tabular}} & \multicolumn{2}{|c|}{$\begin{array}{c}\text { Percentage } \\
\text { nount of total }\end{array}$} & \multicolumn{2}{|c|}{$\begin{array}{cc}\text { Percentage } \\
\text { Amount }\end{array}$} \\
\hline & dollars & percent & dollars & percent & dollars. & percent \\
\hline $\begin{array}{l}\text { Advertising } \\
\text { Office supplies } \\
\text { Utilities } \\
\text { Rent and insurance }\end{array}$ & $\begin{array}{l}185 \\
415 \\
389 \\
320\end{array}$ & $\begin{array}{l}1.6 \\
3.5 \\
3.3 \\
2.7\end{array}$ & $\begin{array}{l}304 \\
598 \\
570 \\
573\end{array}$ & $\begin{array}{l}1.6 \\
3.0 \\
2.9 \\
2.9\end{array}$ & $\begin{array}{l}105 \\
293 \\
268 \\
152\end{array}$ & $\begin{array}{l}1.5 \\
4.3 \\
4.0 \\
2.2\end{array}$ \\
\hline $\begin{array}{l}\text { Grading and veter- } \\
\text { inary service } \\
\text { Wages, bonuses, }\end{array}$ & 349 & 2.9 & 451 & 2.3 & 281 & 4.1 \\
\hline and operating & 5,856 & 49.1 & 9,764 & 49.7 & 3,250 & 47.9 \\
\hline $\begin{array}{l}\text { Officers' and direc- } \\
\text { tors' salaries }\end{array}$ & 1,245 & $10 . \frac{4}{6}$ & 2.324 & 11.8 & 526 & 7.8 \\
\hline Taxes & 739 & 6.2 & 1,248 & 6.3 & 400 & 5.9 \\
\hline Pepairs & 387 & 3.2 & 608 & 3.1 & 239 & 3.5 \\
\hline Depreciation & 478 & 4.0 & 414 & 2.1 & 521 & 7.7 \\
\hline Operating and & & & & & & \\
\hline $\begin{array}{l}\text { trading loss } \\
\text { Miscellaneous }\end{array}$ & $\begin{array}{l}626 \\
948\end{array}$ & $\frac{5.2}{7.9}$ & $\begin{array}{l}1,231 \\
1,577\end{array}$ & $\begin{array}{l}6.3 \\
8.0\end{array}$ & $\begin{array}{l}223 \\
530\end{array}$ & $\begin{array}{l}3.3 \\
7.8\end{array}$ \\
\hline Total & 11,937 & 100.0 & 19,662 & 100.0 & 6,788 & 100.0 \\
\hline \multirow{3}{*}{ Item } & \multicolumn{6}{|c|}{ Average according to type of farming area } \\
\hline & \multicolumn{2}{|c|}{$\begin{array}{c}\text { Eastern livestock } \\
\text { (3 auctions })\end{array}$} & \multicolumn{2}{|c|}{$\begin{array}{c}\text { Central livestock } \\
\text { (5 auctions) }\end{array}$} & \multicolumn{2}{|c|}{$\begin{array}{c}\text { Dairy and general } \\
\text { farming } \\
(2 \text { auctions })\end{array}$} \\
\hline & Amount & $\begin{array}{l}\text { Percentage } \\
\text { of total }\end{array}$ & Amount & $\begin{array}{l}\text { Percentage } \\
\text { of total }\end{array}$ & Amount & $\begin{array}{l}\text { Percentage } \\
\text { of total }\end{array}$ \\
\hline & dollars & percent & dollars & percent & dollars & percent \\
\hline Advertising & 75 & 1.2 & 181 & 1.3 & 359 & 2.2 \\
\hline Office supplies & 273 & 4.5 & 409 & 3.0 & 642 & 3.9 \\
\hline Utilities & 205 & 3.4 & 362 & 2.7 & 730 & 4.4 \\
\hline Rent and insurance & 68 & 1.1 & 409 & 2.9 & 498 & 3.1 \\
\hline $\begin{array}{l}\text { Grading and veter- } \\
\text { inary service } \\
\text { Wages, bonuses. }\end{array}$ & 315 & 5.1 & 385 & 2.8 & 310 & 1.9 \\
\hline $\begin{array}{l}\text { and operating } \\
\text { salaries } \\
\text { officers' }\end{array}$ & 2,658 & 43.3 & 6,717 & 49.4 & 8,498 & 51.5 \\
\hline $\begin{array}{l}\text { Tors's salaries } \\
\text { tors's }\end{array}$ & 806 & 13.1 & $\mathbf{1 , 5 1 8}$ & 11.2 & 1,220 & 7.4 \\
\hline Taxes & 350 & 5.7 & 881 & 6.5 & 968 & 5.9 \\
\hline Repairs & 293 & 4.8 & 480 & 3.5 & 295 & 1.8 \\
\hline Depreciation & 348 & 5.7 & 541 & 4.0 & 518 & 3.1 \\
\hline $\begin{array}{l}\text { Operating and } \\
\text { trading loss }\end{array}$ & 322 & 5.3 & 794 & $5 *$ & 663 & 4.0 \\
\hline Miscellaneous & 415 & $\begin{array}{l}0.0 \\
6.8 \\
\end{array}$ & 934 & 6.9 & 1,784 & 10.8 \\
\hline Total & 6,131 & 100.0 & 13,602 & 100.0 & 16.485 & 100.0 \\
\hline
\end{tabular}


nels of trade at different points along the way to slaughter, depending upon whether buyers are local dealers or representatives of packing companies. Other systems of marketing may bring the consignor nearer the ultimate processor. When this is the case, producers will want to consider the increased income that may result from such sales policies, even though marketing costs are higher. For example, if the farmer gets 50 cents more per 100 pounds when dealing with an agency that takes his stock all the way to the ultimate processor, he is ahead if the additional marketing costs of obtaining such an increase in gross returns are any amount less than 50 cents per 100 pounds - the increase in gross returns. It has been mentioned previcusly that the final test of an effective marketing system for the farmer, all other factors considered, is whether it gives him the greatest net income, and not whether is renders the cheapest selling service. Unfortunately, no acceptable data are available as to grades, market costs, and prices for most classes of West Virginia livestock which vill give a satisfactory answer to this problem.

\section{MARKET RELATIONSHIPS}

Farmers reporting on livestock marketing practices were asked to indicate criticisms, strong points, and suggestions for improvement of livestock auctions. These expressions should be helpful to operators in enabling them to give attention to needed adjustments and in helping them to improve their relationships with farmers and with other marketing agencies.

Criticisms of auction markets were summarized by 399 farmers as follows:

\section{Types of criticism}

Unstable and low prices

Unethical trading practices

Collusion among buyers

Not enough buyers

Poor and close grading

Spreads disease

Too expensive

Too many pinhookers

Requires trucking

Not suitable for selling finished cattle

Not suited for small farms

Unclassified

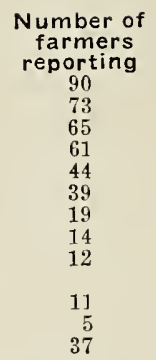

Many farmers were impressed by the rath $\subseteq r^{\circ}$ unstable price situation existing at local auctions. This was particularly true where auctions became quite dependent upon a limited number of buyers. Furthermore, this criticism was closely related to another criticism, that of collusion among buyers. Some of the more important additional criticisms stressed by farmers included un ethical trading practices (faulty weighing, collusion among employees, improper grading methods, and the prevalence of pinhookers). While these problems all are important, they indicate need for attention by management, rather than inherent shortcomings of auction operation.

The strong points of auction operation as indicated by 507 farmers were summarized as follows:

\section{Strong points}

A good market for all

kinds of livestock

An available market at all times

A good market for special kinds of livestock

More competition

Better prices

Furnish market information

Improved marlieting services

Unclassified

$\begin{gathered}\text { Number of } \\ \text { farmers } \\ \text { reporting }\end{gathered}$
167
143
139
98
81
72
30
38

It may be noted that some of the principal advantages given for auction operation center around improved market outlets. Farmers were of the opinion that, in general, auctions furnished a good market for all types of livestock. Those in need of money were in position to sell one or two head at any time rather than 
being dependent upon local dealers. Practically all farmers have access to as many as three or four auctions. Furthermore, while some local buyers were interested in only one grade or class of livestock, auctions furnished outlets for most grades and classes. Other advantages stressed by farmers related to such items as more competition, better prices, the furnishing of market information, and improved marketing services. Some farmers were of the opinion that the experience of observing at first hand the relationship of prices to quality was of definite educational value.

Suggestions offered for improvement of auctions centered around such items as elimination of pinhookers, better management, more buy$\epsilon r s$, closer supervision of weighing, improvements in grading, and better sanitation practices.

In general, increased competition among livestock buyers resulting from auction operation has enabled many farmers to get relatively more for their livestock than they had been able to realize through sales to local dealers. It should be men- tioned, however, that the increased competition claimed for auctions was often more imaginative than real. At times there was collusion between buyers. At other times very few buyers were present at auction sales. Even though 15 to 20 active buyers attend an auction sale, the competition may not be nearly as great as supposed. In many instances they desire only special grades and classes of livestock. In other instances the amount of livestock that such dealers purchased was limited to a truckload or a carload. Under such conditions, competition was furnished cinly during that part of the sale when these buyers were actively bidding. There were of course a varying number of potential bidders who were usually ready to step in if auction prices got appreciably out of line.

The farmer must also use care in buiying at auction markets. He must not permit the chant of the auctioneer or the influence of the crowd to cause him to bid higher than normal market prices for the feeder or breeder stock he desires.

\section{CONCLUSIONS AND RECOMMENDATIONS}

The many changes that have taken place in livestock marketing in West Virginia during the past two decades call for reappraisal of the operation of marketing agencies serving farmers. In order better to evaluate their operation, it is important to recognize the influence of such factors as: (1) the nature of livestock markets; (2) characteristics of marketing agencies; and (3) the influence of such factors as the increased use of truck transportation, marked growth of livestock auctions, and the treerd toward decentralization of livestock markets.

Livestock marketing agencies in
West Virginia have undergone significant modifications in organization and operating methods because of changing conditions. It is recognized that each agency possesses certain advantages and disadvantages from the standpoint of the farmer. The farmers is interested in understanding the nature of the market services performed by various agencies. He is concerned with their efficiency of operation. Furthermore, he is interested in acquainting himself with pussibilities for improvement in the operation of these agencies. Finally, it should be kept in mind that any evaluation of the performance of 
livestock-marketing agencies in West Virginia should be undertaken with the realization that on a large numker of farms the livestock enterprise is relatively small, that quality varies considerably from farm to farm and from area to area, and that better feeding and breeding methods would enaule many producers to avail themselves of market outlets that are not open to them.

\section{LOCAL SLAUGHTERHOUSES}

The trend toward established standards for the production of meat and meat byproducts indicates the likelihood of growing consumer interest in the operation of local slaughterhouses. This may result in demands for the inspection of all animals killed at local slaughterhouses and for the operation of these plants in accordance with reasonable sanitary standards. Such development depends upon the establishment and enforcement of effective control measures.

Control and regulation of local slaughterhouse operation has usually been directed toward such items as buildings, yards, equipment, facilities, water supply, sewerage disposal, delivery equipment, reports on the nature and extent of business operation, examination of livestock, and the meeting of established health standards by working personnel. State agencies have the double responsibility of establishing such controls for the improvement of the local slaughtering industry, an industry upon which a considerable number of farmers depend, directly or indirectly, for a livestock market, as well as for safeguarding the health of its citizens.

\section{LOCAL LIVESTOCK DEALERS}

In general, the development of cooperative associations and auction markets restricted the field of ac- tivity of many local dealers. These agencies have, more or less, superimposed themselves on the localdealer system of operation. There is evidence to indicate that local dealers, to the extent that they render the services desired by farmers, will continue to be an important agency in the marketing of West Virginia livestock. Some, however, will need to reexamine their methods of operation if they are to continue to be successful. Their position might be strengthened by giving attention to such factors as: (1) increasing the efficiency of operation, (2) improving the performance of services rendered farmers, and (3) adjusting operating methods to correspond with changes in the organization and o peration of livestock-marketing agencies.

Those charged with the responsibility of safeguarding the interests of livestock producers might well give attention to possibilities of establishing reasonable controls on localdealer operation. Significant features of such legislation, as developed in some states, include: licensing provisions, (2) keeping of records and accounts, (3) testing of scales used by local dealers, (4) bonding, and (5) penalties for violations of established regulations.

\section{COOPERATIVE LIVESTOCK MARKETING ASSOCIATIONS}

The organization structure and the cperating practices of cooperative livestock marketing associations in West Virginia indicate that definite problems exist. Solution of these problems would do much to improve the status of livestock-marketing cooperatives. As a basis for strengthening organization structure and for improving operating methods, the following recommendations are offered:

(1) All cooperative livestock 
marketing associations, through members and directors, should be encouraged to assume full responsibility for weighing lambs, keeping records, and arranging for audits. Experience in cther states and performance in West Virginia have shown that failure to establish such responsibility has a stifling effect on cooperative endeavor. Farmers do not look upon cooperatives as their own agencies until they actively assume responsibility for their operations.

(2) Accounting and auditing procedure will have to be revised if effective checks on performance are to be obtained. Annual statements for local associations should show separate accounts for livestock and wool-marketing activities. Separate accounts also should be available for each of the various species of livestock handled. Certified public accountants ought to be employed as auditors.

(3) Since livestock-marketing associations have direct contact with members only a few times a year, it is important that means be developed to bring about improvement in membership relations and to furnish patrons with general livestock marketing information. To develop effective membership relations, farmers (members and non-members) should become acquainted with the organization set-up and the operating methods of the cooperative associations that are in position to serve them. The development of regular cooperative publications, supplemented with regular newsletters, and the furnishing of simple yet adequate financial statements would help to accomplish this end.

(4) State and area associations would be taking a step forward if they arranged for an annual school for training managers and directors of local livestock cooperatives. This school should be conducted by per- sons well trained in marketing. As. sistance would likely be available from the Producers Cooperative Commission Association and from the Livestock and Wool Section of the Cooperative Research and Service Division of the Farm Credit Administration. Training might include such items as the presentation of such general economic information as applies to livestock marketing, the organization and operating problems of cooperative livestock marketing associations, and the keeping and use of financial records.

(5) Further attention needs to be given to problems of livestock trucking. Especially in the case of cattle and calves, competition from trucker-dealers has been considerable. If cooperative livestock marketing associations are to serve small producers, it will be necessary to furnish trucking service for such farmers.

(6) Consideration needs to be given to expanding the scope of business operations. There are services that can be rendered many farmers in the marketing of cattle and calves and in the obtaining of larger numbers of feeder and breeding livestock. Not only would such a policy enable associations to give more complete marketing services to farmers; it also would contribute to more efficient market operation.

(7) Cooperative livestock a n d wool marketing associations might benefit from the joint employment of a state manager. To assist these associations in coordinating ownership, management, and control in member patrons, such a manager should be thoroughly trained in the principles of marketing and should be paid entirely by and be responsible only to the marketing associations concerned. 


\section{LIVESTOCK AUCTIONS}

Study of the many problems of auction operations in West Virginia suggests numerous possibilities for improvement. On the basis of information obtained, the following recommendations are offered:

(1) Improvement in trading ethics. While not applying to all auctions, there is definite evidence that, in some instances, auction owner's and operators deal in livestock at auction markets. Such practices should be discontinued, especially when there is no explanation concerning the nature of such deals. It is impossible to maintain the good will of other consignors when it is known that their livestock is sold in competition with that of auction owners or operators. Similarly, when owners or operators bid in competition with dealers, the possibility of dissatisfaction among dealers is increased.

(2) Auction operators should discontinue the practice of permitting patent-medicine vendors to use auction facilities for the sale of their products. This practice not only wastes the time of a considerable number of farmers, but it is a practice that has dissocial implications.

(3) "By-bidding" should not be permitted. Pinhookers and certain dealers frequently abuse this practice to the dissatisfaction of legitimate bidders. Protection can be given to consignors either by permitting them to announce "no sale" from the ring or by having them set a minimum price on their livestock at the time of consignment.

(4) Pinhooking should be prohibited. This practice is a source of annoyance to many consignors and of dissatisfaction to farmers. In most instances it is the poorly informed farmer who brings a limited number of animals and who is not adequately acquainted with market con- ditions that is exploited by pinhookers. It is to the credit of one auction owner that he has taken aggressive steps to prohibit pinhooking.

(5) Further improvement in sanitation is desirable. While much progress has been made in this direction, the installation of concrete floors in pens for all livestock sold as feeder or breeding animals and the disinfection of trucks used in the transportation of livestock are precautions that would be in the interest of farmers and auction operators alike.

(6) Operating expenses could be reduced if auction sales were held less frequently during all but peak periods. While some sales are conducted every other week during winter months, it is believed that in most places this practice could be extended to include all but the peak months (August, September, and October).

(7) Complete reports should be filed by all auctions with the State Department of Agriculture as a requirement for obtaining a license to operate. Such reports should furnish information as to number of head of various species of livestock sold, value of sales, and other pertinent information.

(8) Scales should be checked at least four times a year and operated in accordance with state law. Inadequate facilities and limited personnel have not permitted an adequate check on the accuracy of auction scales.

(9) Some auction markets would benefit from consolidation of operations. It was reported that eight small auctions in West Virginia were within 25 miles of other auctions. Under such conditions, operating costs are unnecessarily high, and effective competition among buyers is limited. 




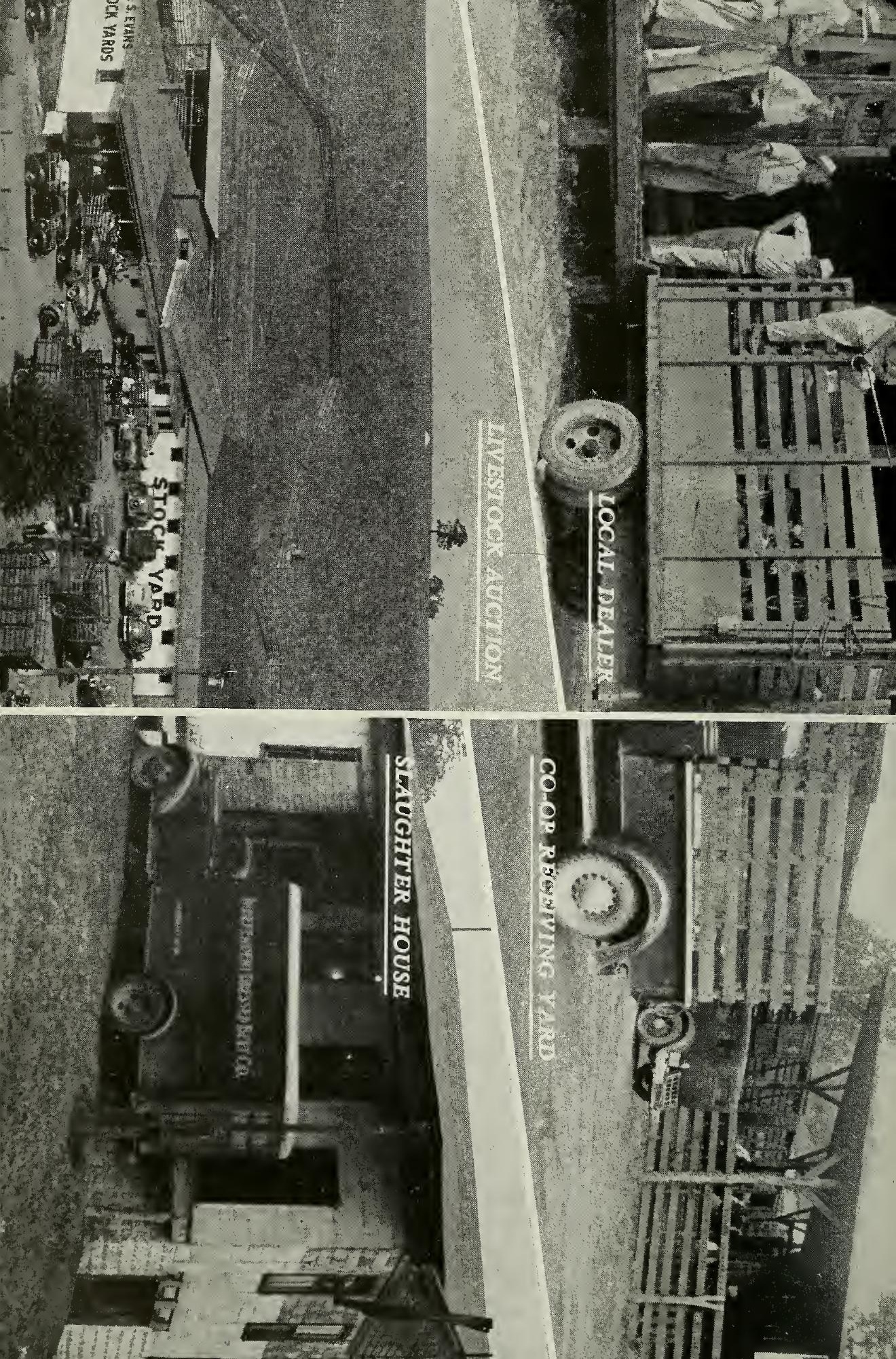



ing 10 